\title{
Remediation of Petroleum Hydrocarbon- Contaminated Ground Water in the Vicinity of a Jet-Fuel Tank Farm, Hanahan, South Carolina
}

By Don A. Vroblesky, J. Frederick Robertson, Matthew D. Petkewich, Francis H. Chapelle, Paul M. Bradley, and James E. Landmeyer

U.S. GEOLOGICAL SURVEY

Water-Resources Investigations Report 96-4251

Prepared in cooperation with the U.S. DEPARTMENT OF DEFENSE, DEFENSE LOGISTICS AGENCY

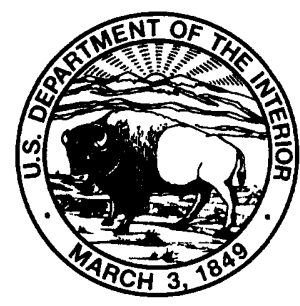




\title{
U.S. DEPARTMENT OF THE INTERIOR \\ BRUCE BABBITT, Secretary
}

\author{
U.S. GEOLOGICAL SURVEY
}

Gordon P. Eaton, Director

The use of firm, trade, and brand names in this report is for identification purposes only and does not constitute endorsement by the U.S. Government.

For additional information write to:

Copies of this report can be purchased from:

\section{District Chief}

U.S. Geological Survey

Stephenson Center-Suite 129

- 720 Gracern Road

Columbia, SC 29210-7651
U.S. Geological Survey

Branch of Information Services

Box 25286

Denver, CO 80225-0286 


\section{CONTENTS}

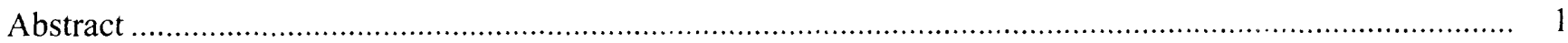

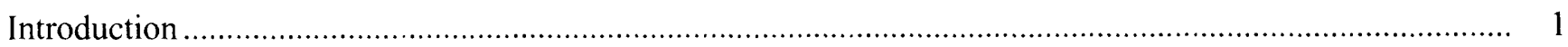

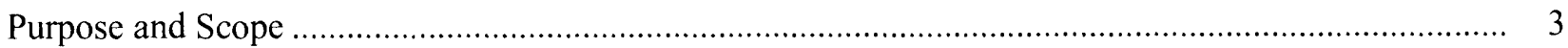

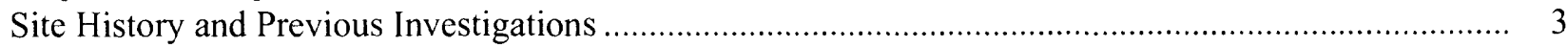

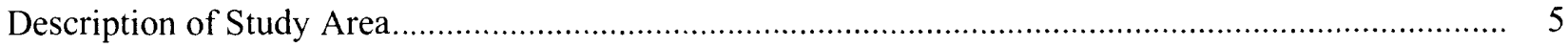

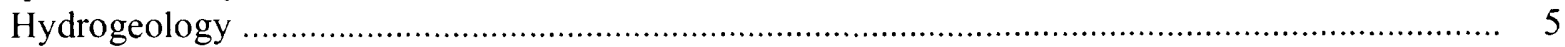

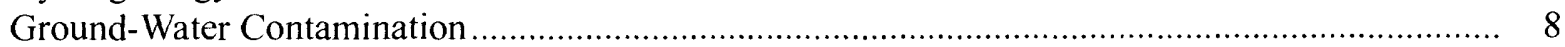

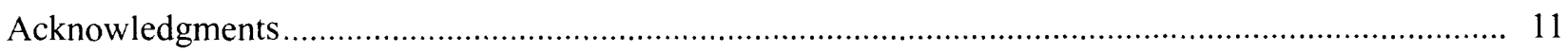

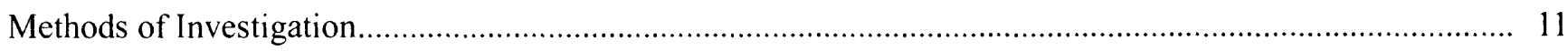

Observation-Well Installation and Construction and Aquifer Testing ......................................... 11

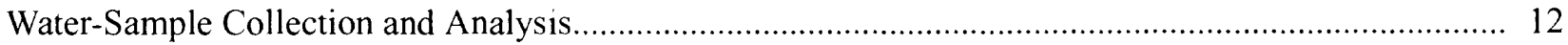

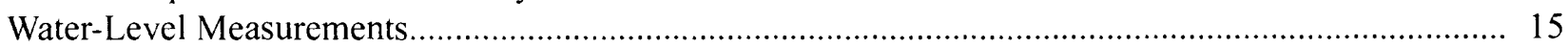

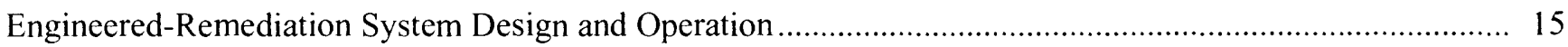

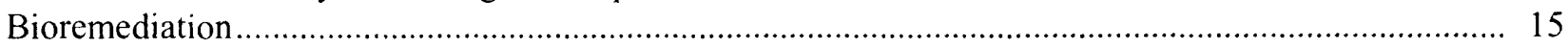

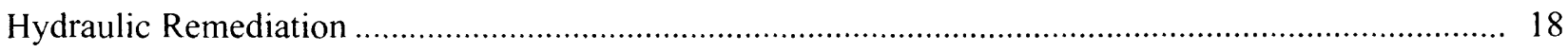

Hydrogeologic and Chemical Factors Affecting Contaminant Movement and

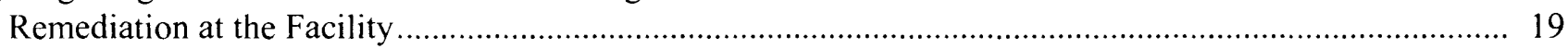

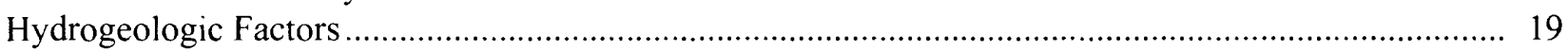

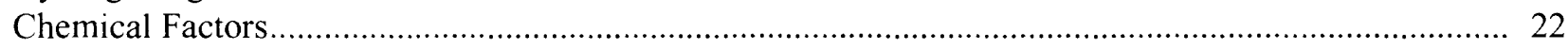

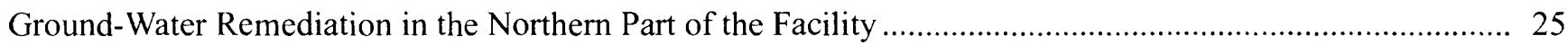

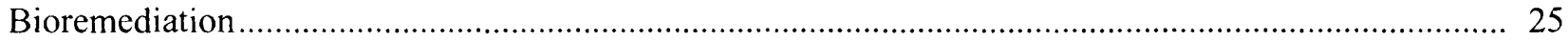

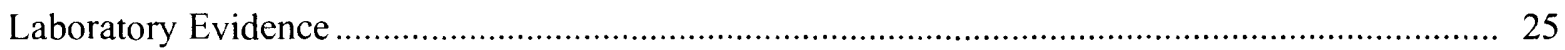

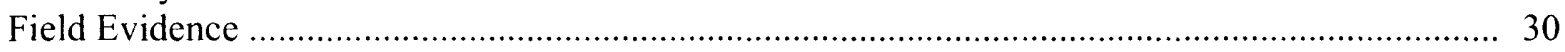

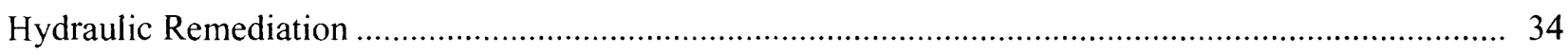

Ground-Water Remediation in Gold Cup Springs Subdivision .................................................. 37

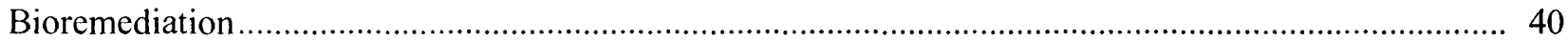

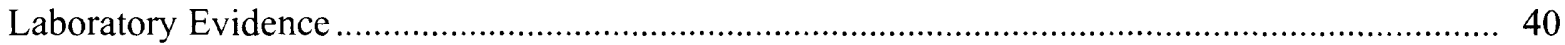

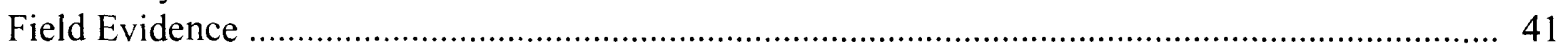

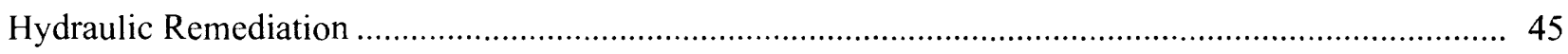

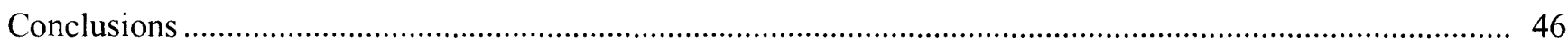

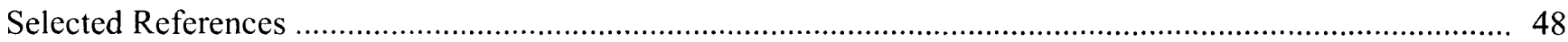


1. Map showing locations of observation wells, surface-water sampling sites, and traces of hydrogeologic sections A-A' and B-B', Defense Fuel Supply Point, Hanahan, S.C. [in pocket]

\section{FIGURES}

1-3. Maps showing:

1. Location of study area, and distribution of free-phase jet fuel and benzene, Defense Fuel Supply Point, Hanahan, S.C

2. Water table in the surficial aquifer at the Defense Fuel Supply Point, Hanahan, S.C., during high ground-water levels, August 31, 1992

3. Water table in the surficial aquifer at the Defense Fuel Supply Point, Hanahan, S.C., during low ground-water levels, January 2, 1992

4. Hydrogeologic section A-A', Defense Fuel Supply Point, Hanahan, S.C.

5. Diagram showing hydraulic and bioremediation system, Defense Fuel Supply Point, Hanahan, S.C.

6. Hydrogeologic section B-B' in tank 1 basin showing approximate location of stratigraphically trapped free-phase fuel, Defense Fuel Supply Point, Hanahan, S.C.

7-11. Maps showing:

7. Areal distribution of terminal electron-accepting processes, based on interpretations of hydrogen measurements in ground water, Defense Fuel Supply Point, Hanahan, S.C., June 1991 and November 1992

8. Distribution of combined benzene, toluene, ethylbenzene, and total xylenes in the shallow part of the surficial aquifer north of tank 3, Defense Fuel Supply Point, Hanahan, S.C., January 1992

9. Distribution of combined benzene, toluene, ethylbenzene, and total xylenes in the shallow part of the surficial aquifer north of tank 3, Defense Fuel Supply Point, Hanahan, S.C., July to August 1995

10. Distribution of combined benzene, toluene, ethylbenzene, and total xylenes in the deep part of the surficial aquifer north of tank 3, Defense Fuel Supply Point, Hanahan, S.C., July 1992

11. Distribution of combined benzene, toluene, ethylbenzene, and total xylenes in the deep part of the surficial aquifer north of tank 3, Defense Fuel Supply Point, Hanahan, S.C., July to August 1995

12-17. Graphs showing:

12. Ground-water chemistry at well EW-11, Defense Fuel Supply Point, Hanahan, S.C., 1993-94

13. Toluene, benzene, and total xylene concentrations in ground water at well MW-12, Defense Fuel Supply Point, Hanahan, S.C., 1990-92...

14. Chloride and toluene concentrations and sulfate/chloride ratios at well MW-12A, Defense Fuel Supply Point, Hanahan, S.C., 1992-93 
15. Toluene concentrations at wells MWGS-33A and MWGS-32A, and specific conductance at well MWGS-33A, Defense Fuel Supply Point, Hanahan, S.C., 1993-94

16. Toluene, chloride, and dissolved oxygen concentrations, $\mathrm{SO}_{4} / \mathrm{Cl}$ ratios at well MWGS-41A, and $\mathrm{SO}_{4} / \mathrm{Cl}$ ratios at infiltration-gallery 2, Defense Fuel Supply Point, Hanahan, S.C., 1993-95.

17. Concentration of combined benzene, toluene, ethylbenzene, and total xylenes in ground water recovered from wells MW-07 and EW-02, Defense Fuel Supply Point, Hanahan, S.C., 1991-95.

18. Map showing distribution of combined benzene, toluene, ethylbenzene, and total xylenes in ground water north of tank 1, Defense Fuel Supply Point, Hanahan, S.C., June to July 1992

19. Map showing distribution of combined benzene, toluene, ethylbenzene, and total xylenes in ground water north of tank 1, Defense Fuel Supply Point, Hanahan, S.C., August 1995.

20-23. Graphs showing:

20. Benzene consumption in sediments under sulfate-reducing conditions following initial feeding and subsequent refeedings, Defense Fuel Supply Point, Hanahan, S.C.

21. Changes in concentrations of ethylbenzene, toluene, total xylenes, and benzene at SW-12, the sampling point for the French drain collecting ground-water from the southeastern side of Valley Drive, Gold Cup Springs subdivision, Hanahan, S.C., 1992-95

22. Changes in concentrations of benzene, hydrogen, sulfate, and ferrous iron in ground water at well MW-04, Defense Fuel Supply Point, Hanahan, S.C., 1991-94

23. Benzene, ethylbenzene, total xylenes, and toluene in ground water at well MWGS-22, Defense Fuel Supply Point, Hanahan, S.C., 1990-95

\section{TABLES}

1. Construction details for observation wells installed by the U. S. Geological Survey at the Defense Fuel Supply Point, Hanahan, S.C.

2. Construction details for privately owned wells and monitoring wells installed during previous investigations in the vicinity of the Defense Fuel Supply Point, Hanahan, S.C. 


\begin{tabular}{|c|c|c|}
\hline Multiply & By & To obtain \\
\hline \multicolumn{3}{|c|}{ Length } \\
\hline inch (in.) & 25.4 & millimeter \\
\hline foot $(\mathrm{ft})$ & 0.3048 & meter \\
\hline foot per foot $(\mathrm{ft} / \mathrm{ft})$ & 0.3048 & meter per meter \\
\hline mile (mi) & 1.609 & kilometer \\
\hline \multicolumn{3}{|c|}{ Area } \\
\hline foot squared per day $\left(\mathrm{ft}^{2} / \mathrm{d}\right)$ & 0.09294 & meter squared per day \\
\hline square mile $\left(\mathrm{mi}^{2}\right)$ & 2.590 & meter squared per day \\
\hline \multicolumn{3}{|c|}{ Flow } \\
\hline foot per day $(\mathrm{ft} / \mathrm{d})$ & 0.3048 & meter per day \\
\hline gallons per minute (gal/min) & 0.06308 & liter per second \\
\hline gallons per day (gal/d) & 0.003785 & cubic meter per day \\
\hline inches per year (in./yr) & 25.4 & millimeters per year \\
\hline \multicolumn{3}{|c|}{ Volume } \\
\hline gallon (gal) & 3.785 & liter \\
\hline
\end{tabular}

Temperature: In this report, temperature is given in degrees Celsius $\left({ }^{\circ} \mathrm{C}\right)$, which can be converted to degrees Fahrenheit $\left({ }^{\circ} \mathrm{F}\right)$ by the following equation:

$$
{ }^{\circ} \mathrm{F}=\left(9 / 5 \times{ }^{\circ} \mathrm{C}\right)+32
$$

Sea Level: In this report, "sea level" refers to the National Geodetic Vertical Datum of 1929--a geodetic datum derived from a general adjustment of the first-order level nets of the United States and Canada, formerly called Sea Level Datum of 1929.

Chemical concentration: In this report, chemical concentration in water is expressed in metric units as milligrams per liter $(\mathrm{mg} / \mathrm{L})$ or micrograms per liter $(\mu \mathrm{g} / \mathrm{L})$.

Transmissivity: The standard unit for transmissivity is cubic foot per day per square foot times foot of aquifer thickness $\left[\left(\mathrm{ft}^{3} / \mathrm{d}\right) / \mathrm{ft}^{2}\right] \mathrm{ft}$. In this report, the mathematically reduced form, foot squared per day $\left(\mathrm{ft}^{2} / \mathrm{d}\right)$, is used for convenience.

Biodegradation rate constant: In this report, first-order kinetics are used to describe the biodegradation rate of toluene. First-order rate constants $\left(\mathrm{K}_{\mathrm{tol}}\right)$ are expressed in units of percent of compound degraded per day (pct/d). Because percent in dimensionless, this reduces to units of inverse days $\left(\mathrm{d}^{-1}\right)$.

Specific conductance is given in microsiemens per centimeter at 25 degrees Celsius $\left(\mu \mathrm{S} / \mathrm{cm}\right.$ at $\left.25^{\circ} \mathrm{C}\right)$.

Other units used in this report:

$\begin{array}{ll}\text { gram } & \mathrm{g} \\ \text { liter } & \mathrm{L} \\ \text { micrograms } & \mu \mathrm{g} \\ \text { micromoles } & \mu \mathrm{M} \\ \text { micrometer } & \mu \mathrm{m} \\ \text { microliter } & \mu \mathrm{L} \\ \text { milligrams } & \mathrm{mg} \\ \text { milliliter } & \mathrm{mL} \\ \text { milliliter per minute } & \mathrm{mL} / \mathrm{min} \\ \text { millimoles } & \mathrm{mM} \\ \text { nanomoles } & \mathrm{nM}\end{array}$


Abbreviations and acronyms used in this report:

\begin{tabular}{|c|c|}
\hline bls & below land surface \\
\hline${ }^{14} \mathrm{CH}_{4}$ & carbon-14 labeled methane \\
\hline$\left[2-{ }^{14} \mathrm{C}\right]$-acetate & carbon-14 labeled acetate \\
\hline${ }^{14} \mathrm{CO}_{2}$ & carbon-14 labeled carbon dioxide \\
\hline $\mathrm{CO}_{2}$ & carbon dioxide \\
\hline BTEX & combined benzene, toluene, ethylbenzene, and total xylenes \\
\hline $\mathrm{Cl}$ & chloride \\
\hline DFSC & Defense Fuel Supply Center \\
\hline DFSP & Defense Fuel Supply Point \\
\hline DIC & dissolved inorganic carbon \\
\hline DO & dissolved oxygen \\
\hline $\mathrm{Fe}(\mathrm{III})$ & ferric iron \\
\hline $\mathrm{Fe}(\mathrm{II})$ & ferrous iron \\
\hline $\mathrm{GC}$ & gas chromatograph \\
\hline $\mathrm{H}_{2}$ & dissolved hydrogen \\
\hline $\mathrm{H}_{2} \mathrm{O}_{2}$ & hydrogen peroxide \\
\hline $\mathrm{H}_{2} \mathrm{~S}$ & hydrogen sulfide \\
\hline ID & inside diameter \\
\hline lsd & land surface datum \\
\hline MCL & maximum contaminant level \\
\hline $\mathrm{N}$ & nitrogen \\
\hline $\mathrm{NO}_{3}$ & nitrate \\
\hline OD & outside diameter \\
\hline PVC & polyvinyl chloride \\
\hline SCDHEC & South Carolina Department of Health and Environmental Control \\
\hline SS & stainless steel \\
\hline $\mathrm{SO}_{4}$ & sulfate \\
\hline TEAP & terminal electron-accepting process \\
\hline TOC & total organic carbon \\
\hline $\mathrm{TPH}$ & total petroleum hydrocarbons \\
\hline USAEHA & U.S. Army Environmental Hygiene Agency \\
\hline USDOD & U.S. Department of Defense \\
\hline USEPA & U.S. Environmental Protection Agency \\
\hline USGS & U.S. Geological Survey \\
\hline
\end{tabular}




\title{
Remediation of Petroleum Hydrocarbon-Contaminated Ground Water in the Vicinity of a Jet-Fuel Tank Farm, Hanahan, South Carolina
}

\author{
By Don A. Vroblesky, J. Frederick Robertson, Matthew D. Petkewich, Francis H. Chapelle, \\ Paul M. Bradley, and James E. Landmeyer
}

\section{Abstract}

Substantial decreases in petroleum-hydrocarbon concentrations in contaminated ground water at a tank farm in Hanahan, South Carolina, were observed during operation of an engineered hydraulic and bioremediation system. For example, in the shallow part of the surficial aquifer north of tank 3 at wells MWGS32A and MWGS-33A, the combined concentrations of benzene, toluene, ethylbenzene, and total xylenes decreased from greater than 1,000 micrograms per liter prior to operation of the system to less than 100 micrograms per liter following operation. Groundwater contamination persisted in parts of the aquifer not affected by the infiltration-gallery water, such as in the deeper part of the surficial aquifer (about 16-30 feet below land surface) north of tank 3 , and in source areas upgradient from the remediation system that continued to leach occasional hydrocarbon pulses to the aquifer. Laboratory and field evidence showed that reductions in contaminant concentrations were caused by engineered and natural bioremediation as well as hydraulic remediation.

The persistence of ground-water contamination north of tank 1 is caused by the presence of free-phase fuel stratigraphically trapped below the water table and isolated from the influence of recharge-gallery water. Investigation of the aquifer chemistry demonstrated that inefficient microbial electron-accepting processes tend to dominate in zones contaminated with petroleum hydrocarbons. The system, however, could shift to more efficient electron-accepting processes with the addition of more efficient electron acceptors, such as oxygen and nitrate.

\section{INTRODUCTION}

In October 1975, an estimated 83,000 gal of jet fuel (JP-4) leaked from tank 1 at the Defense Fuel Supply Point (DFSP), a military storage facility for jet fuel, hereafter referred to as the facility, in Hanahan, S.C. (U.S. Army Environmental Hygiene Agency, 1975). The leak resulted in a plume of petroleum hydrocarbons in the ground water north of tank 1 (fig. 1). An additional plume of petroleum hydrocarbon-contaminated ground water subsequently was found north of tank 3 .

In 1987, the U.S. Geological Survey (USGS), in cooperation with the U.S. Department of Defense (USDOD), Defense Logistics Agency, investigated the potential for bioremediation of the ground-water contamination. The project involved the operation and evaluation of an engineered ground-water remediation system. The remediation system consisted of microbiological and hydraulic decontamination elements. As part of the study, the USGS extensively investigated the aquifer hydrogeology and geochemistry and used laboratory and field methods to investigate the site microbiology. Although the study area included the facility and surrounding areas, the investigation concentrated on the northern part of the facility and the ground-water-contamination plumes extending northward into Gold Cup Springs subdivision. 


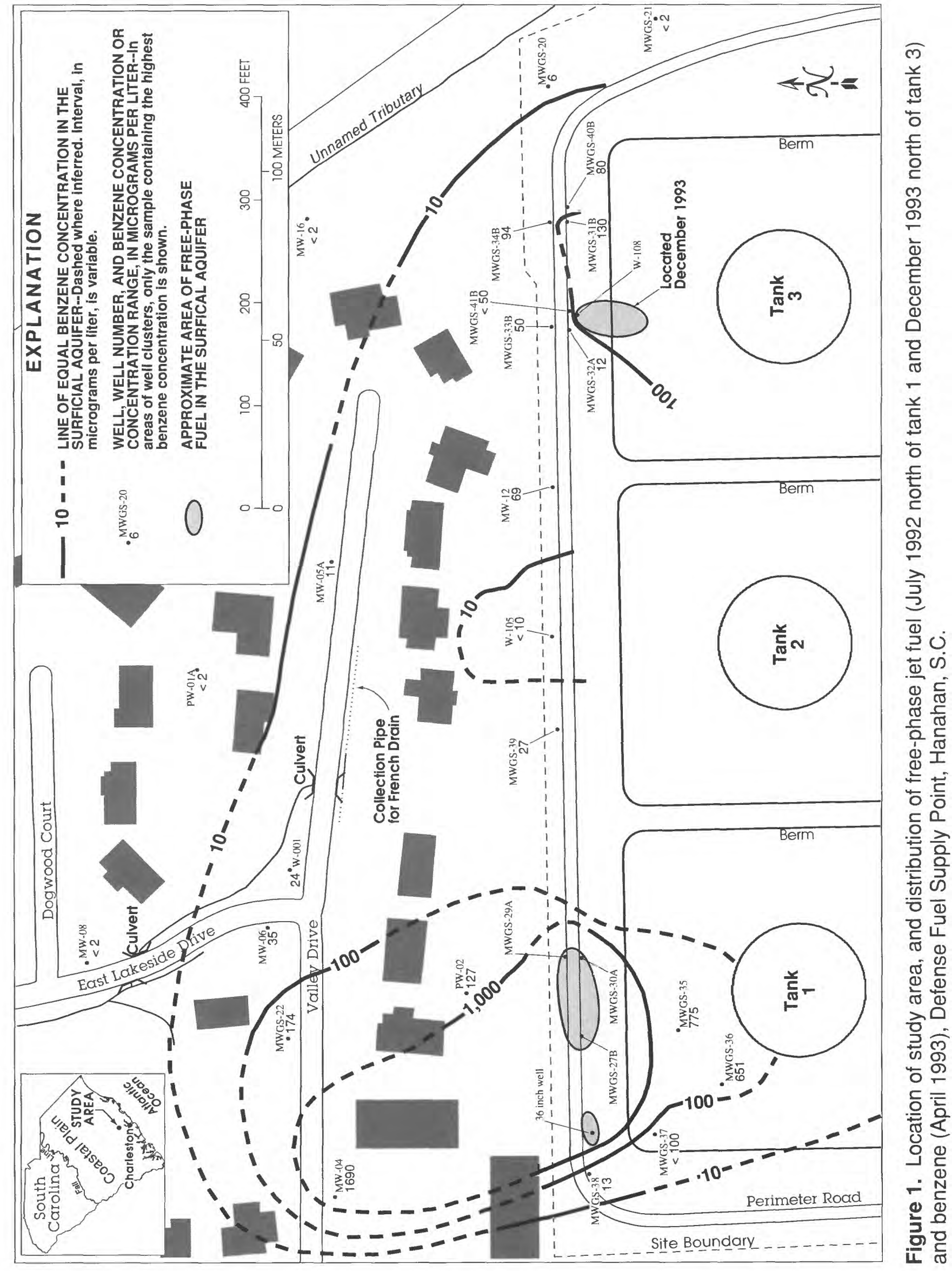

2 Remediation of Petroleum Hydrocarbon-Contaminated Ground Water in the Vicinity of a Jet-Fuel Tank Farm, Hanahan, South Carolina 


\section{Purpose and Scope}

The purpose of this report is to present the evaluation results of ground-water remediation in the study area. The investigation examined ground-water hydrology, chemistry, and microbiology in the northern part of the facility and in parts of Gold Cup Springs subdivision, north of the facility.

To determine the effectiveness of the ground-water remediation system, many factors influencing the ground-water hydrology, chemistry, and microbiology were examined. This investigation included the installation of monitoring wells; the collection of sediment samples for chemical and microbial evaluation, and lithologic description; the extensive collection of groundwater samples for chemical analysis; and the monthly collection of water-level data, as well as continuously recorded water-level data from two monitoring wells. Water-quality, water-level, and sediment data collected during this investigation for the period between December 1990 and January 1996 are presented in a separate report (Petkewich and others, in press). In addition, data obtained during previous investigations at the facility were collected, compiled, and evaluated to provide historical information regarding site conditions, as well as to provide useful information to be integrated with data collected during this investigation.

\section{Site History and Previous Investigations}

The JP-4 leak from tank 1 at the facility occurred soon after the tank was filled on October 16, 1975. Losses of fuel were noted throughout the month, and on November 4, the tank was closed, and a leak was confirmed.

On November 13, 1975, Soil Consultants, Inc., drilled 12 boreholes in the vicinity of tank 1 to determine the areal extent and magnitude of the spill. The plume of subsurface fuel was at a depth of 7 to $12 \mathrm{ft}$ below land surface (bls) (U.S. Army Environmental Hygiene Agency, 1975). The contamination encompassed an area of $20,000 \mathrm{ft}^{2}$ around the northern part of the storage tank and was moving approximately $5 \mathrm{ft} / \mathrm{d}$ toward the northwest (U.S. Army Environmental Hygiene Agency, 1977).

During December 1975, the U.S. Army Environmental Hygiene Agency (USAEHA) recovered approximately 25 percent $(20,750 \mathrm{gal})$ of the leaked fuel (U.S. Army Environmental Hygiene Agency, 1977). Initial fuel recovery (approximately 1,000 gal/d) was accomplished by pumping approximately $650 \mathrm{gal} / \mathrm{min}$ of combined fuel and water from 50 well points in the tank 1 basin to an oil/water separator. Most of the recovery took place between December 4-7. The combined water and jet-fuel recovery rapidly declined during the operation to about 30 to $50 \mathrm{gal} / \mathrm{min}$ (about $400 \mathrm{gal} / \mathrm{d}$ of fuel) because of pumpagerelated water-level declines. After about 2 weeks of pumping, jet-fuel recovery further diminished, and the well points were removed. An interceptor trench, approximately 17 -ft deep and encompassing about $80 \mathrm{ft}^{2}$, was excavated north of tank 1 to allow venting of fuel vapors for approximately 1 month before the trench was refilled (U.S. Army Environmental Hygiene Agency, 1988).

The USAEHA (1977) constructed a second recovery system consisting of 40 well points in March 1976. A pumping rate of only $50 \mathrm{gal} / \mathrm{min}$ total flow was obtained from the new well points, and there was no measurable accumulation of fuel in the oil/water separator or in the pump discharge. After about a month, pumping yield rates declined further, and the recovery effort was terminated. Following an unusually heavy rainfall in September 1979, the residents of Gold Cup Springs subdivision began complaining of fuel odors. The following month, the South Carolina Department of Health and Environmental Control (SCDHEC) installed four observation wells along the northern perimeter of the tank farm. Evidence of petroleum contamination was in the four wells (U.S. Army Environmental Hygiene Agency, 1988). As a result of these observations, a third fuel-recovery effort was initiated in November 1979, which included installation of a 36-in.diameter recovery well north of tank 1 (U.S. Army Environmental Hygiene Agency, 1988). 
The earliest investigation of the subsurface microbiology at the facility was by the USAEHA (1977). The investigators reported that all the collected soils contained microorganisms capable of metabolizing JP-4 constituents.

In 1980, the Defense Fuel Supply Center (DFSC), the coordination organization for the facility, contracted Dames \& Moore, Inc. to develop an on-site investigation and monitoring program to assess the extent of ground-water contamination at and near the tank farm. As part of the investigation, lithologic samples were collected at 17 boreholes at the facility. Observation wells (wells W-101 to W-108 and B-101 to B-109) were installed in the boreholes (existing wells shown on pl. 1). Dames \& Moore, Inc. (1982) reported a sheen on the water surface in seven observation wells. These and other data implied that residual hydrocarbon contamination was present in the soil and was being flushed into the ground water by rainfall and water-level changes. Dames \& Moore, Inc. (1982) recommended that no additional ground-water cleanup was needed because (1) there was no gross contamination of ground water, (2) repairs had already been made to the tanks, (3) improvements had been made to the facility operational practices, and (4) there were no existing ground-water users immediately downgradient.

In the spring of 1984, the residents of Gold Cup Springs subdivision again reported contamination problems. They complained of objectionable odors, a thick scum on the top of the Gold Cup Springs Lake (pl. 1), and oily deposits in the lake bottom (Daubel, 1984). The USAEHA responded by collecting seven surface-water samples in and around the subdivision and the facility and three ground-water samples from the northern boundary of the facility. Ground water from some wells contained benzene, toluene, ethylbenzene, and total xylenes (collectively termed BTEX). Surface-water samples from near the oil/water separator on the eastern side of the facility and at one site in Gold Cup Springs Lake contained tank-bottom residue from a recent discharge from the facility through the oil/water separator
(Daubel, 1984). In response to this finding, the DFSP ceased discharging tank-bottom residues to surface water (McClelland Engineers, Inc., 1987a).

Because of the growing public and State concern over ground-water contamination at this and other sites in the area, the U.S. Department of Defense (USDOD) began the Confirmation and Quantification stage of the Installation Restoration Program for potential USDOD-related toxic and hazardous sites in and near Charleston Air Force Base. Ground-water samples collected from DFSP during this investigation showed $44,000 \mathrm{mg} / \mathrm{L}$ of oil and grease in well W-103 (Science Applications International Corporation, 1985). Following this finding, three offsite wells were installed (wells W-001, W-002, and W-003) (pl. 1).

Responsibility for continued site investigation was transferred from the DFSC to the U.S. Navy in 1986. The Navy organized the investigation around the Navy Assessment and Control of Installation Pollutants Program and contracted McClelland Engineers, Inc., to plan and implement a Characterization Step study.

An investigation by McClelland Engineers, Inc., (1987a) included the installation and sampling of seven observation wells, sampling of four privately owned wells in Gold Cup Springs subdivision, and collection and analysis of soil and soil-gas samples. The study indicated that part of the JP-4 ground-water contamination from tank 1 was discharging to a spring-fed stream and flowing northward toward Gold Cup Springs Lake. A subsequent study (McClelland Engineers, Inc., 1987b) reported evidence of leaks around tanks 1, 2 , and 3 , and evidence of three contamination plumes in the ground water. The main plume of ground-water contamination was moving north from tank 1 toward East Lakeside Drive, and another plume appeared to be moving west from the facility. A third plume was discovered north of tank 3 and did not appear to be related to JP-4 from tank 1 .

In 1987, RMT, Inc. was contracted to complete an aquifer evaluation of the site. These 
investigations showed that BTEX contamination was present in streams and ground water in the subdivision. In addition, low concentrations of fuel-related aromatic and nonaromatic vapors were present in some houses (RMT, Inc., 1987; 1988a; 1988b; 1989a; 1989b; 1989c; 1990).

In 1987, the USGS began investigations at the facility to determine the potential for in situ bioremediation of the ground-water contamination at the site. Initial findings of the investigation showed that naturally occurring bacteria were present in the surficial aquifer and were capable of rapidly degrading some JP-4 components during aerobic metabolism and during anaerobic metabolism coupled to nitrate reduction (Francis H. Chapelle, U.S. Geological Survey, written commun., 1988).

As a result of the initial phase of the USGS investigation, an engineered bioremediation system was designed by RMT, Inc. (1989d) and installed at the facility in 1990 . A permit to operate the system was issued on January 14, 1992, by the SCDHEC.

\section{Description of Study Area}

The facility is in the lower Coastal Plain physiographic province of South Carolina (fig. 1) and is underlain by Quaternary, Tertiary, and Cretaceous deposits overlying crystalline rock of preCretaceous age. The hydrogeologic units in the study area included, from shallowest to deepest, the surficial aquifer, the Cooper Group/Cross Formation confining unit, and the Santee Limestone/ Black Mingo aquifer. This investigation focused on the surficial aquifer. Lithologic descriptions of the sediments were based on data obtained from numerous borings made during this and previous investigations. Lithologic and stratigraphic descriptions of units below the surficial aquifer were obtained from drill cuttings and borehole geophysical logging during the installation of infiltration-gallery supply well DW-1.

\section{Hydrogeology}

The facility and adjacent areas are underlain by unconsolidated Quaternary fluvial and marine deposits consisting of very fine- to mediumgrained quartz sand and silty sand with discontinuous layers of clay, clayey sand, and sandy clay. The Quaternary sediments in the vicinity of the facility range in thickness from approximately 39 $\mathrm{ft}$ at well B-103 to about $11 \mathrm{ft}$ at well MW-09 (Dames \& Moore, Inc., 1982; McClelland Engineers, Inc., 1987a) (pl. 1). These sediments compose the surficial aquifer. The unconformable contact between the Quaternary sediments and the underlying Cooper Group/Cross Formation confining unit at the facility typically is marked by a layer of phosphatic pebbles and shell fragments.

Calculated hydraulic conductivities in the surficial aquifer ranged from 0.5 to $8 \mathrm{ft} / \mathrm{d}$ in slug tests done at three wells during this investigation. A previous investigation also used slug tests to calculate hydraulic conductivity and obtained values ranging from 1.1 to $3.7 \mathrm{ft} / \mathrm{d}$ at four wells in Gold Cup Springs subdivision (McClelland Engineers, Inc., 1987a).

The Quaternary sediments composing the surficial aquifer are unconformably underlain by upper Oligocene and upper Eocene-age deposits referred to as the Cooper Group (Gohn and others, 1977; Ward and others, 1979). The Cooper Group is comprised of dense, phosphatic, calcareous silty to sandy clay (calcarenite) and dense, phosphatic and glauconitic calcilutite. The middle to upper Eocene-age Cross Formation, directly beneath the Cooper Group, is a dense, partially silicified calcilutite. Cooper Group sediment of only a few feet thick is dense enough to retard the vertical movement of water (Park, 1985). At the facility, the Cooper Group is about 225-ft thick and the combined Cooper Group/Cross Formation thickness is about $270 \mathrm{ft}$ (well DW-1) (Kevin Conlon, U.S. Geological Survey, oral commun., 1996). The combined thickness is an effective confining unit, hydraulically isolating the surficial aquifer from deeper water-bearing units. 
The Cross Formation is underlain by the middle Eocene-age fossiliferous Santee Limestone and the upper Paleocene-age limestones, sands, and clays of the Black Mingo Group. The two formations have been considered to be hydraulically connected and have recently been referred to as the Santee Limestone/Black Mingo aquifer (Park, 1985; Meadows, 1987). The aquifer at the facility is confined, with the potentiometric surface at approximately $240 \mathrm{ft}$ above the base of the overlying confining unit. A 24-hour pumping test in the aquifer (well DW-1) showed the transmissivity to be $575 \mathrm{ft}^{2} / \mathrm{d}$ (Newcome, 1993). The supply well drilled at the facility (well DW-1) was completed with an open-hole section from 305 to $381 \mathrm{ft}$ bls and is considered to have penetrated the upper portion of the Black Mingo Group.

Recharge to the surficial aquifer beneath the facility and adjacent areas primarily was derived from rainfall infiltration. Based on measurements obtained at the Charleston Airport, approximately 3 mi west of the facility, the average annual rainfall from 1961-90 was approximately $51.5 \mathrm{in} . / \mathrm{yr}$ (National Oceanic and Atmospheric Administration, 1995), of which approximately $6 \mathrm{in} . / \mathrm{yr}$ or less is thought to recharge the ground water in the South Carolina Coastal Plain (Newcome, 1989). Localized recharge also was provided by seasonally losing reaches of the stream immediately east of the facility and by infiltration of water from the engineered remediation system in the northern part of the facility.

Ground water locally discharged from the surficial aquifer to springs, a French-drain system south of Valley Drive, gaining streams, and Gold Cup Springs Lake (pl. 1). Evapotranspiration provided an additional water-removal mechanism. Once the engineered remediation system was placed into operation, ground water also was removed by extraction wells along the north end of the facility and in the subdivision. Because the lower confining unit beneath the facility was approximately $270-\mathrm{ft}$ thick, vertical movement of water through the unit was considered to be negligible.
Much of the shallow ground water beneath the facility is derived from local recharge, as evidenced by the permeable soil, the local mounding during periods of high ground-water levels (fig. 2 ), and the typically downward vertical head gradients in the northern part of the facility. At wells MW-12 and MW-12A, water levels were typically 0.31 to $1.05 \mathrm{ft}$ higher in the shallower well relative to the deeper well, indicating a downward gradient. Similarly, north of tank 3 at well clusters MWGS-31A and -31B and MWGS-34A and $-34 \mathrm{~B}$, the higher water levels in the shallowest wells relative to the deeper wells indicated a downward gradient. Occasional gradient reversals were observed at the remaining well clusters in the facility north of tank 3 , possibly as a result of extraction and infiltration associated with the engineered remediation system.

Ground-water discharge took place in Gold Cup Springs subdivision, as shown by the springs, gaining streams, and localized flooding during periods of high ground-water levels. The vertical head differences at wells MW-05 and MWGS$05 \mathrm{~A}$ in the subdivision, varied from $-0.59 \mathrm{ft}$ to $+0.58 \mathrm{ft}$. The upward gradients generally were observed during periods of high ground-water levels, suggesting that the area locally functioned as a discharge zone during high ground-water levels.

Ground-water levels fluctuated seasonally and with rainfall events. The greatest amounts of rainfall and the highest ground-water levels typically were observed during the spring and summer. The greatest seasonal water-level variation observed was $6.01 \mathrm{ft}$ at well B-102, on the facility. Water-level variations of about $1.71 \mathrm{ft}$ were measured in well MW- 08 , located in a topographically low area of the Gold Cup Springs subdivision.

In the northern part of the facility, additional water-level changes were caused by the engineered remediation system. During the operation of the remediation system, about 16 percent of the extracted water from the entire system was replenished with infiltration-gallery water, indicating a net removal of ground water. 


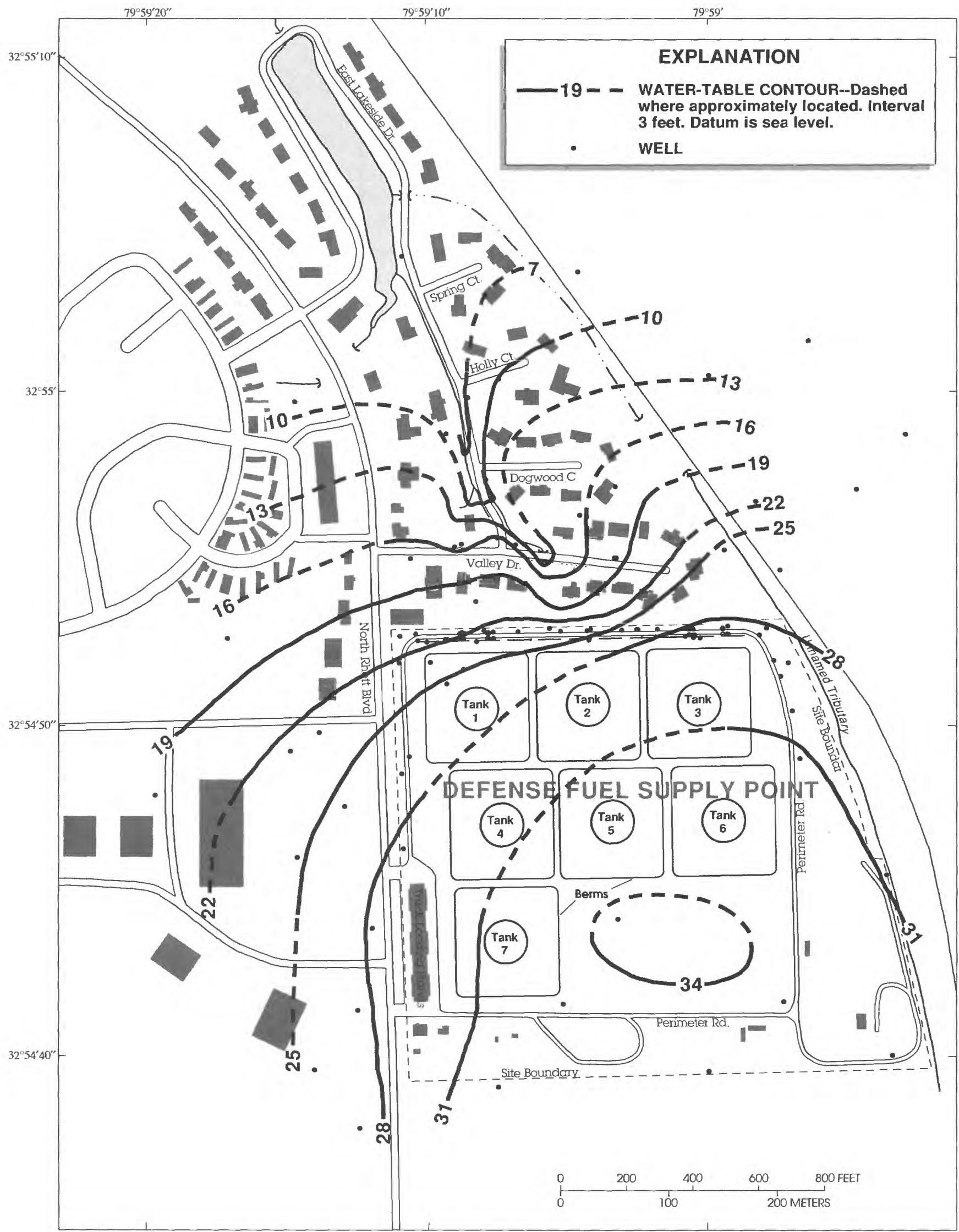

Figure 2. Water table in the surficial aquifer at the Defense Fuel Supply Point, Hanahan, S.C., during high ground-water levels, August 31, 1992. 
The dominant direction of ground-water flow in the surficial aquifer beneath the northern part of the facility is northwest (figs. 2 and 3). In the southern part of the facility, ground-water flow directions varied throughout the year. The ground-water flow direction in the southern part of the facility was typically northward to northwestward during low ground-water levels (fig. 3). During high ground-water conditions, however, water-table mounding was observed south of tanks 5 and 6, which resulted in radial flow (fig. 2).

The area north of tank 1 at wells MW-11 and MW-11A (pl. 1) contains locally confined conditions. Despite the short horizontal distance between the wells (about $3 \mathrm{ft}$ ) and the short vertical distance (about $9 \mathrm{ft}$ ) between the screened intervals of these wells, a pronounced downward hydraulic gradient always was present when the water levels were measured. Water-level differences between the wells were typically from 1 to $2.6 \mathrm{ft}$, but were as much as $4.5 \mathrm{ft}$ following heavy rains. Boring logs indicate that the surficial aquifer north of tank 1 contains multiple clay or sandy clay layers and lenses ranging in thickness from about 0.5 to $3 \mathrm{ft}$ and beginning at a depth of about $7 \mathrm{ft}$ bls (fig. 4). East of well W-105, clay layers do not appear to exhibit substantial hydraulic control.

\section{Ground-Water Contamination}

The dominant contaminants in the ground water at the facility were petroleum hydrocarbons derived from fuel spilled or leaked onto the ground. To a large extent, the concentrations of dissolved oxygen (DO), nitrate, ferrous iron (Fe[II]), sulfate, organic acids, and several other constituents in the ground water were controlled by microbial activity related to the petroleumhydrocarbon distribution. Microbial production of organic acids in the contaminated ground water north of tank 1 resulted in enhanced mineral dissolution (McMahon and others, 1995).

The presence of free-phase fuel in the aquifer and in the unsaturated zone beneath the facil- ity resulted in ground-water contamination by petroleum hydrocarbons. The most soluble components of the contamination (benzene, toluene, ethylbenzene, and total xylenes) were transported northward into Gold Cup Springs subdivision. The distribution of benzene, the BTEX compound of greatest regulatory concern, showed that ground-water contamination originated from tank 1 and tank 3 basins (fig. 1). Other organic compounds detected included naphthalene, nitrobenzene, a variety of pentane and hexane isomers, and methyl- and alkyl-benzenes.

Arsenic concentrations locally were elevated above the $50 \mu \mathrm{g} / \mathrm{L}$ Maximum Contaminant Level (MCL) for drinking water (U.S. Environmental Protection Agency, 1991; 1996) in the deeper part of the surficial aquifer north of tank 3 . The maximum arsenic concentration measured in ground water at well MWGS-31B (pl. 1) was $781 \mu \mathrm{g} / \mathrm{L}$, in July 1993. The lack of known arsenic sources at the facility and the close correlation of elevated arsenic concentrations with elevated organic-acid, petroleum-hydrocarbon, and $\mathrm{Fe}$ (II) concentrations suggest that arsenic may have been mobilized from the sediment by microbial activity associated with petroleum-hydrocarbon degradation.

Lead was present in ground water north of tank 3. Although concentrations remained below the MCL of $50 \mu \mathrm{g} / \mathrm{L}$ for drinking water (U.S. Environmental Protection Agency, 1991), some were higher than the action level of $15 \mu \mathrm{g} / \mathrm{L}$ (U.S. Environmental Protection Agency, 1996). The maximum lead concentration measured in ground water was $48.3 \mu \mathrm{g} / \mathrm{L}$ at well PW-01 A in January 1994, and concentrations of lead in the facility north of tank 3 occasionally ranged from 10 to $40 \mu \mathrm{g} / \mathrm{L}$. In background areas and north of tank 1 , the lead concentrations typically were less than $0.5 \mu \mathrm{g} / \mathrm{L}$. These data imply that part of the contamination north of tank 3 was derived from combat gasoline, formerly stored in tank 3. Lead potentially can have inhibitory effects on the microbial community, but probably not at the concentrations generally found at the facility (Bradley and others, 1993a; 1993b). 


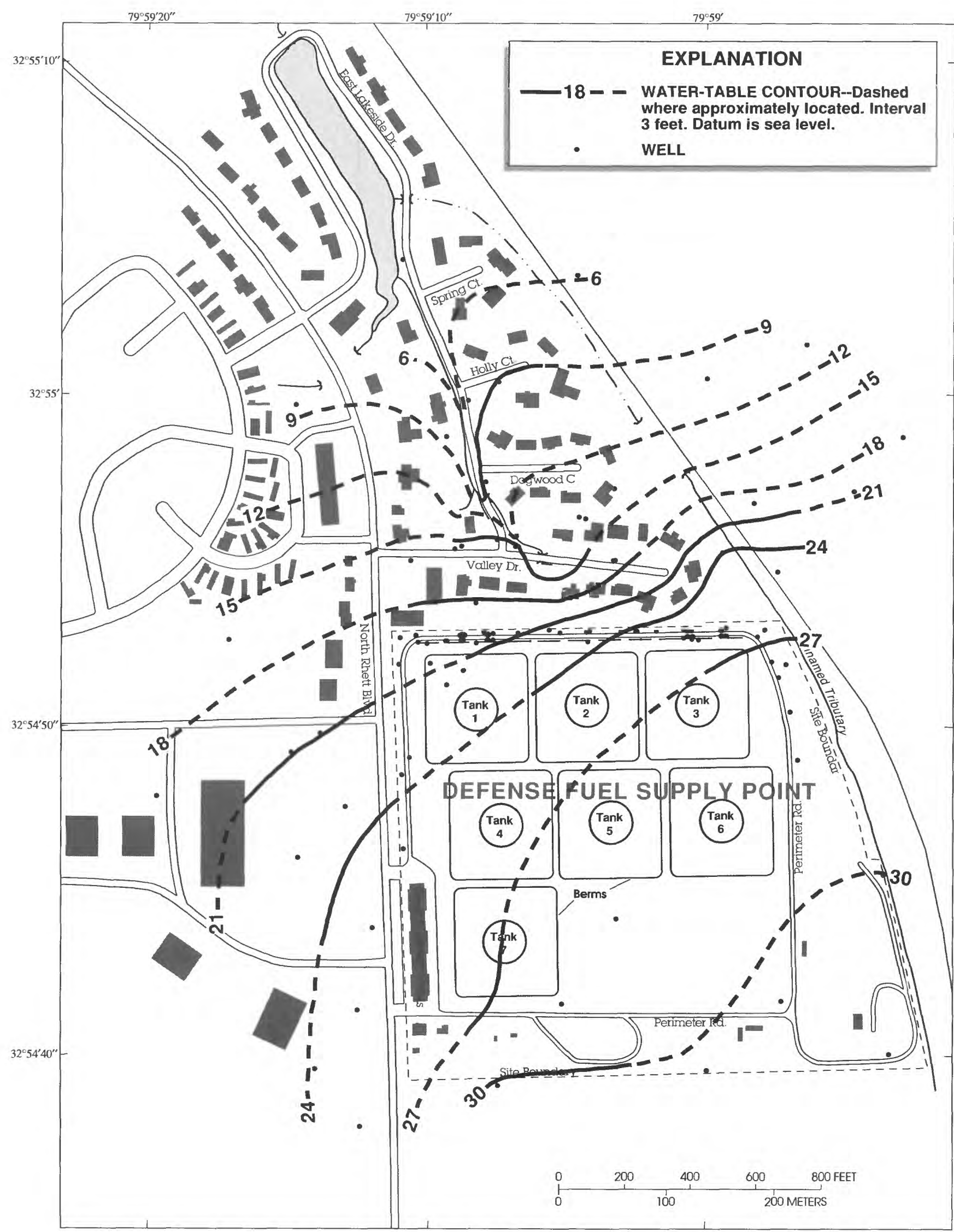

Figure 3. Water table in the surficial aquifer at the Defense Fuel Supply Point, Hanahan, S.C., during low ground-water levels, January 2, 1992. 

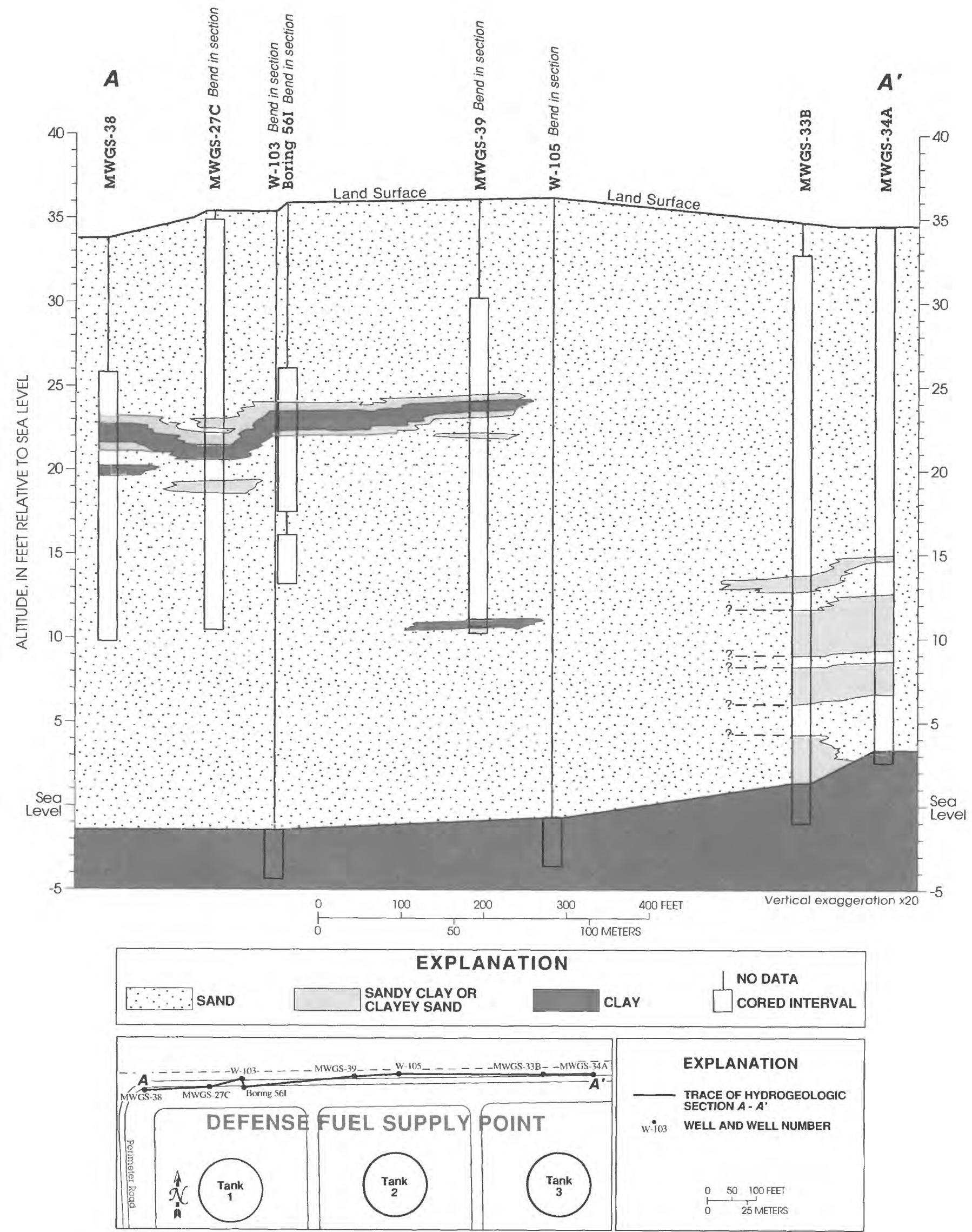

Figure 4. Hydrogeologic section A-A', Defense Fuel Supply Point, Hanahan, S.C.

10 Remediation of Petroleum Hydrocarbon-Contaminated Ground Water in the Vicinity of a Jet-Fuel Tank Farm, Hanahan, South Carolina 
Unlike the area north of tank 1 , where contamination was concentrated near the water table, the contamination north of tank 3 extended through at least the upper $15 \mathrm{ft}$ of the aquifer. The shallowest ground-water contamination north of tank 3 was intercepted in Gold Cup Springs subdivision by French-drain systems south of Valley Drive (fig. 1). Deeper contamination, however, apparently continued moving past the drain systems northward, as evidenced by occasional detections of BTEX compounds and arsenic in ground water at well MWGS-05A.

\section{Acknowledgments}

Special thanks are deserved by the operators of the DFSP facility for their cooperation, and particularly to Don Matthews for his assistance and facilitation of system repairs. In addition, several residents of Gold Cup Springs subdivision generously allowed access to their property. S.R Hutchins and C.M. Aelion assisted in early phases of the drilling and sampling program.

\section{METHODS OF INVESTIGATION}

Standard methods were used in this investigation to obtain water-quality and water-level data. Specific methods used during monitoringwell installation and development, and collection of water-quality and water-level data are discussed in the following sections.

\section{Observation-Well Installation and Construction and Aquifer Testing}

A total of eighty-five monitoring wells and piezometers were installed at or near the facility by the USGS or under direction of the USGS (pl. 1). All wells were installed in the surficial aquifer from June 1990-94. Generally, the USGS wells were installed to provide geochemical and waterlevel data where previously unobtained at locations and depths that complemented the coverage of monitoring wells installed during previous investigations. Construction details of wells installed by the USGS are listed in table 1 (at end of report). Water-level and geochemical data also were collected by the USGS from most of the monitoring wells installed during previous investigations in the vicinity of the facility, as well as from privately owned domestic wells located in Gold Cup Springs subdivision. Available wellconstruction data for these wells are presented in table 2 (at end of report).

Observation wells installed by the USGS were identified by the prefix MWGS- followed by the numbers 5 and 20 through 63 . Well pairs and clusters were further identified alphabetically to indicate relative depths, with the letter A representing the shallowest well of the pair or cluster; $\mathrm{B}$ identifying the next deeper well; $\mathrm{C}$ identifying the third deeper well of a cluster, and so forth. For example, MWGS-27A is the shallowest well of the MWGS-27 cluster, and MWGS-27C is the deepest, with MWGS-27B at an intermediate depth. Well MWGS-05A, however, was installed adjacent to a previously existing well, MW-05, and is the deepest of the pair. Piezometers installed by the USGS were identified by the prefix WT- followed by sequential numbers 1 through 11.

Specific wells and groups of wells were installed for various purposes. Wells MWGS-42 through MWGS-63 were installed in the tank 1 basin for use as test galleries for tracer tests and other experiments. The WT-series wells were installed primarily for gathering water-level data. Well pairs and clusters were installed to assess the vertical distribution of contaminants.

All MWGS-series wells were installed using hollow-stem augers. All WT-series piezometers were installed using a coring hand auger. Well clusters MWGS-23, MWGS-24, MWGS-25, and MWGS-26 were constructed with 0.25 -in. outside-diameter (OD) stainlesssteel tubing, with each cluster installed in a single, respective borehole. Screened intervals for these wells were constructed of $0.2-\mathrm{ft}$ lengths of 60 mesh stainless-steel screen. Well clusters MWGS-27 and MWGS-28 were constructed with 
1-in. inside-diameter (ID) polyvinyl chloride (PVC) flush-threaded pipe with slotted-screen sections cut to desired lengths in the field. Well clusters MWGS-23, MWGS-24, MWGS-25, MWGS-26, MWGS-27, and MWGS-28 were installed by a USEPA drill crew in cooperation with the USGS. Wells MWGS-35 through MWGS-39 were constructed with 4-in. ID flushthreaded PVC pipe and slotted screen (0.010-in. slots). All other MWGS- and WT-series wells were constructed with 2-in. ID flush-threaded PVC monitor pipe and slotted screen (0.010-in. slots). In most cases, the screened section of shallower wells was placed to bracket the water table, unless the depth to the water table was too shallow to allow such placement. The annular space around the screened sections of all wells was filled with clean filter sand to various heights (minimum of $1 \mathrm{ft}$ ) above the top of the screens. A bentonite seal was placed above the filter sand, and the wells were grouted to land surface. With the exception of wells MWGS-42 through MWGS-63, the annular space above the bentonite seal in all wells was filled with cement grout to just below land surface and finished at land surface with a concrete pad and a protective cover. Because of their intended use as temporary wells, wells MWGS-42 through MWGS-63 were sealed to land surface with bentonite and were not finished with protective covers.

Observation wells were developed either by bailing with Teflon bailers dedicated to individual wells or by pumping until the withdrawn water was clear. The amount of water required to be withdrawn varied from well to well. All water withdrawn during development was contained in waste-water holding tanks on the facility.

Negative-displacement slug tests provided data for estimation of aquifer hydraulic conductivity. The screened intervals of wells used for slug testing were fully saturated during the tests. Head changes during the testing were monitored using a data logger and pressure transducers. Slug tests at wells WT-11, MW-10, and MW-15 were analyzed using the Bouwer and Rice method
(1976), with resulting hydraulic-conductivity values of $0.5 \mathrm{ft} / \mathrm{d}, 6 \mathrm{ft} / \mathrm{d}$, and $8 \mathrm{ft} / \mathrm{d}$, respectively.

\section{Water-Sample Collection and Analysis}

Ninety-one wells and 13 surface-water sites located on and adjacent to the facility were sampled intermittently during this investigation from December 1990 to January 1996. Between 49 and 79 wells were sampled on a quarterly basis from January 1992 to July 1995 . The actual number of surface-water sites sampled each quarter varied somewhat, but typically, all 13 sites were sampled. Extraction wells were sampled on a monthly basis between March 1992 and September 1995, depending on their operational status. The infiltration gallery port, IG-2, was sampled on a monthly basis between September 1993 and September 1995.

All monitoring wells were purged of casing water prior to collecting ground-water samples. At least 3 casing volumes of water were removed from each well with either a Teflon bailer, a peristaltic pump with silicon tubing, or a 1.8-in. diameter stainless-steel submersible pump with a rubber hose, except for wells that were bailed dry prior to removing three casing volumes. Because the extraction wells pump continuously, they could be sampled without additional purging. Each well was sampled immediately following bailing. All purge water was contained in wastewater holding tanks located on the facility.

Most monitoring wells sampled in this study were assigned a dedicated Teflon bailer to collect samples. A few wells were sampled using a common bailer that was decontaminated prior to sampling by washing with a detergent solution and rinsing with deionized water. The silicon tubing used in conjunction with the peristaltic pump was decontaminated by pumping approximately $1 \mathrm{~L}$ of deionized water through the system prior to sampling each well. The outside of the silicon tubing was rinsed with deionized water. The submersible pump and hose were decontaminated by pumping at least $25 \mathrm{gal}$ of a detergent solution through the system and then rinsing with approxi- 
mately 25 gal of tap water. The outside of the hose and pump were scrubbed with the detergent solution and then rinsed with tap water. Prior to collecting filtered samples at each well, the filter stands and membrane filters were rinsed thoroughly with deionized water, followed by a rinse with ground water from the well.

Dissolved oxygen, ferrous iron, and total sulfide concentrations were measured in the field. After well purging, the dissolved-oxygen concentration in water from each well was determined by Winkler titration (Hach Company, 1983). Ferrous iron was analyzed using the Hach colorimeter/FerroZine method (Stookey, 1970). Total sulfide present as hydrogen sulfide $\left(\mathrm{H}_{2} \mathrm{~S}\right)$ or acid-soluble metallic sulfides was determined in the field using a colorimetric method (Hach Company, 1983). By allowing particulate matter in the samples to settle and by sampling the clear supernatant, the results presented here represent the approximate concentrations of dissolved $\mathrm{H}_{2} \mathrm{~S}$.

Specific conductance, $\mathrm{pH}$, and water temperature were measured after collecting the dissolved-oxygen sample using techniques described by Wood (1976). Specific conductance was measured with a Yellow Springs Instrument model 33 $\mathrm{SCT}$ meter. The $\mathrm{pH}$ was measured using a digital $\mathrm{pH}$ meter equipped with a combination $\mathrm{pH}$ electrode and an automatic temperature-compensator probe. Water temperature was measured with the $\mathrm{pH}$ meter or a mercury-filled glass thermometer marked in increments of $0.1^{\circ} \mathrm{C}$. Specific conductance in the surficial aquifer also were measured by continuous specific conductance recorders (recorded at 15-minute intervals) in four 2-in. ID wells (MWGS-33A, MWGS-33B, MWGS-34A, and MWGS-34B) located on the facility (pl. 1).

Alkalinity titrations were completed in the field on $100-\mathrm{mL}$ filtered samples during the December 1990, and the June, July, and October 1991 sampling events. Each sample was stirred slowly, using a battery-powered magnetic stirrer, while a Hach Digital Titrator was used to add 0.16-normal sulfuric acid solution to the sample until a $\mathrm{pH}$ endpoint of 4.5 was reached. Alkalinity was calculated as the endpoint of the cumulative volume of added acid as a function of $\mathrm{pH}$.

Water samples for analysis of BTEX, total petroleum hydrocarbons (TPH), total organic carbon (TOC), and naphthalene were collected by slowly filling sample-rinsed glass bottles from a bottom-discharge bailer. The bottles were allowed to overflow several seconds, and the samples were then either preserved with 3 drops of hydrochloric acid (BTEX samples), preserved with sulfuric acid (TPH and TOC samples), or not preserved (naphthalene samples). All sample bottles were capped with Teflon-lined bottle caps. If aeration of a BTEX sample was suspected, or if bubbles were observed in a bottle, the sample was discarded, and a new sample was collected. Ground-water samples for analysis of BTEX and naphthalene were collected in $40-\mathrm{mL}$ glass bottles; TPH and TOC samples were collected in 1-L and $200-\mathrm{mL}$ amber glass bottles, respectively. The water samples for analysis of BTEX, TPH, TOC, and naphthalene were delivered to a private laboratory on the day of collection for analysis by USEPA methods 8020, 418.1, 415.1, and 8020 respectively (U.S. Environmental Protection Agency, 1983; 1986). The water samples collected on February 28, 1995, for analysis of BTEX were analyzed by USEPA method 8240 (U.S. Environmental Protection Agency, 1986).

Water samples for analysis of inorganic ions were collected using either a syringe or a peristaltic pump. Water samples were collected in sample-rinsed polyethylene bottles after passing through a $0.45 \mu \mathrm{m}$ porous-membrane filter. The inorganic ion samples were packed in ice immediately following collection. Ammonium, calcium, magnesium, potassium, and sodium were separated in the laboratory by ion-exchange chromatography using chemical suppression and conductivity detection. Chloride, bromide, nitrate, nitrite, phosphate, and sulfate were analyzed in the laboratory by ion-exchange chromatography using chemical suppression and conductivity detection using USEPA method 300.0 (U.S. Environmental Protection Agency, 1983). 
Water samples for analysis of organic acids were collected in sample-rinsed $40-\mathrm{mL}$ amber glass bottles similar to the BTEX-sample collection. The organic acid samples were not preserved, but were capped with Teflon-lined septa, and placed on ice. Samples were analyzed for acetate, formate, propionate, and butyrate by ionexclusion chromatography using chemical suppression and conductivity detection.

Water samples for analysis of lead and arsenic were collected in sample-rinsed $500-\mathrm{mL}$ polyethylene bottles after passing through a $0.45-\mu \mathrm{m}$ porous-membrane filter. Samples were packed on ice and delivered to a private laboratory on the day of collection for analysis using USEPA methods 7060 and 7421 (U.S. Environmental Protection Agency, 1986).

Methane and dissolved inorganic carbon (DIC) samples were collected using a syringe to inject $5 \mathrm{~mL}$ of sample water into sealed septated vials through a $0.45-\mu \mathrm{m}$ porous-membrane filter. The syringe and vials were rinsed with filtered sample water prior to sampling. The samples were packed in ice to minimize concentration changes due to microbial activity. Methane was quantified by thermal-conductivity-detection gas chromatography. Dissolved methane concentrations were calculated using Henry's Law coefficients (Stumm and Morgan, 1981). The DIC samples were acidified in the laboratory with a 42.5 percent phosphoric acid solution, and DIC concentrations were quantified by thermal-conductivity-detection gas chromatography. Because DIC samples were collected with headspace in the vials and gas chromatography attributes all carbon in this headspace to the DIC concentration, ambient air samples were collected and analyzed for carbon to correct the DIC concentrations for carbon present in the atmosphere.

For quality control and assurance measure of combined sampling and analytical repeatability, replicate samples were collected from at least 10 percent of the total number of wells sampled for each sample event. Duplicate samples not showing analytical agreement were reanalyzed when possible.
Dissolved hydrogen gas was measured in ground water to provide an indicator of the predominant microbially mediated terminal electronaccepting processes (TEAP's). The concept was introduced by Lovley and Goodwin (1988). This approach has been used to document the zonation of TEAP's in a variety of aquifer systems (Chapelle and Lovley, 1990; 1992; Chapelle and McMahon, 1991; Chapelle and others, 1995; Lovley and others, 1994a; Vroblesky and Chapelle, 1994). These studies indicate that hydrogen concentration ranges of 5 to $25 \mathrm{nM}$ (nanomoles) are characteristic of methanogenesis; 1 to $4 \mathrm{nM}$ are characteristic of sulfate reduction; and 0.1 to $0.8 \mathrm{nM}$ are characteristic of ferric iron (Fe[III]) reduction. Because hydrogen is an extremely transitory intermediate, with a half life of less than a minute (Conrad and others, 1987), it is a useful constituent for documenting temporal as well as spatial variations in TEAP's. In this study, hydrogen concentrations were used in conjunction with concentrations of other microbially active solutes to document the spatial and temporal variations in TEAP's.

Ground-water hydrogen samples were collected using the bubble-strip method of Chapelle and McMahon (1991). A stream of water was pumped from the well through a gas-sampling bulb at an approximate rate of $600 \mathrm{~mL}$ per minute. An injected bubble of nitrogen in the bulb asymptotically collected hydrogen and other soluble gases until equilibrium was achieved. Once equilibrium was achieved (less than 5 percent change in 5 minutes, which typically occurred within 15 minutes of initiating the flow of water through the bulb), gas was extracted from the bulb using a gas-tight syringe. Hydrogen was measured in the field at the time of sample collection using a gas chromatograph equipped with a reduction gas detector. The detection limit of the method on samples collected from this site varied between 0.1 and $0.5 \mathrm{nM}$. Hydrogen samples typically were not collected if the ground water at the well was aerobic. All hydrogen samples were collected as duplicates. Each duplicate was separately analyzed; however, hydrogen values were 
reported as average values. Differences between duplicate samples were typically less than 10 percent.

A detailed analysis of major volatile and semivolatile compounds present in ground water in the study area was completed for 19 water samples, including 2 replicates. This analysis provided a list of tentatively identified compounds present in the water samples, an estimated concentration of each tentatively identified compound, and in most cases, a probability base matching number representing the probability of accurately identifying each specific compound. The water samples were collected in July 1991, July 1992, and May 1993 from 17 wells located on and adjacent to the facility. Volatile organic samples were collected in $40-\mathrm{mL}$ glass vials and were preserved with hydrochloric acid. Semivolatile organic samples were collected in 1-L amber glass bottles and were not preserved. The volatile and semivolatile samples were placed on ice and delivered to a private laboratory on the same day of collection for analysis by USEPA methods 8240 and 8270, respectively (U.S. Environmental Protection Agency, 1986).

\section{Water-Level Measurements}

Water levels were measured in 97 wells and at 4 surface-water sites located on the facility and adjacent properties to characterize the shape and slope of the water-table surface in the study area and to record how this surface changed over time. Water levels were measured on a monthly basis in selected wells. The total number of water levels measured each month varied; however, all waterlevel measurements were made within an 8-hour period for each given month. All of the wells measured were screened in the surficial aquifer.

Water levels in the surficial aquifer also were measured by continuous water-level recorders (recorded at 15-minute intervals) in three 6-in. ID wells (W-103, W-107, and W-108) located on the facility ( $\mathrm{pl} .1$ ). Elevations, relative to sea level, were determined for established measuring points at each well and surface-water site by differential leveling to provide a common datum.
Measurements in wells were made using a weighted steel tape to determine the depth of water from the measuring point. At least two measurements were made in each well to ensure precision. Water-level measurements at surfacewater sites were obtained using a stadia rod to determine the vertical distance from the water surface to the permanent measuring points. All water-depth data were corrected to sea level.

\section{ENGINEERED-REMEDIATION SYSTEM DESIGN AND OPERATION}

The ground-water remediation system consisted of (1) a line of infiltration galleries to allow artificial recharge to the aquifer, (2) a nutrientinjection system to amend the infiltration-gallery water as a means of enhancing microbial degradation of the contamination, and (3) a line of extraction wells and an additional well in Gold Cup Springs subdivision to capture most of the contaminated ground water moving from upgradient source areas (fig. 5). The remediation system was designed primarily to address ground-water contamination moving northward from the north end of the facility, although extraction wells also were installed along the northeastern side of the facility to intercept contamination mapped by a soil-gas survey (Vroblesky and others, 1992) and apparently emanating from the vicinity of the truckloading stands (pl. 1).

\section{Bioremediation}

Engineered bioremediation at the facility involved mechanical delivery of oxygen- and nitrate-amended water to stimulate the growth of indigenous subsurface hydrocarbon-degrading micro-organisms. Oxygen is a highly efficient electron acceptor for petroleum-hydrocarbon biodegradation; however, delivery to the aquifer is problematic because of its low solubility in water and because delivery as hydrogen peroxide $\left(\mathrm{H}_{2} \mathrm{O}_{2}\right)$ is expensive and may lower aquifer permeability (Pardieck and others, 1992). Nitrate is a reasonable alternative to oxygen because of its high solubility and comparatively low cost. 


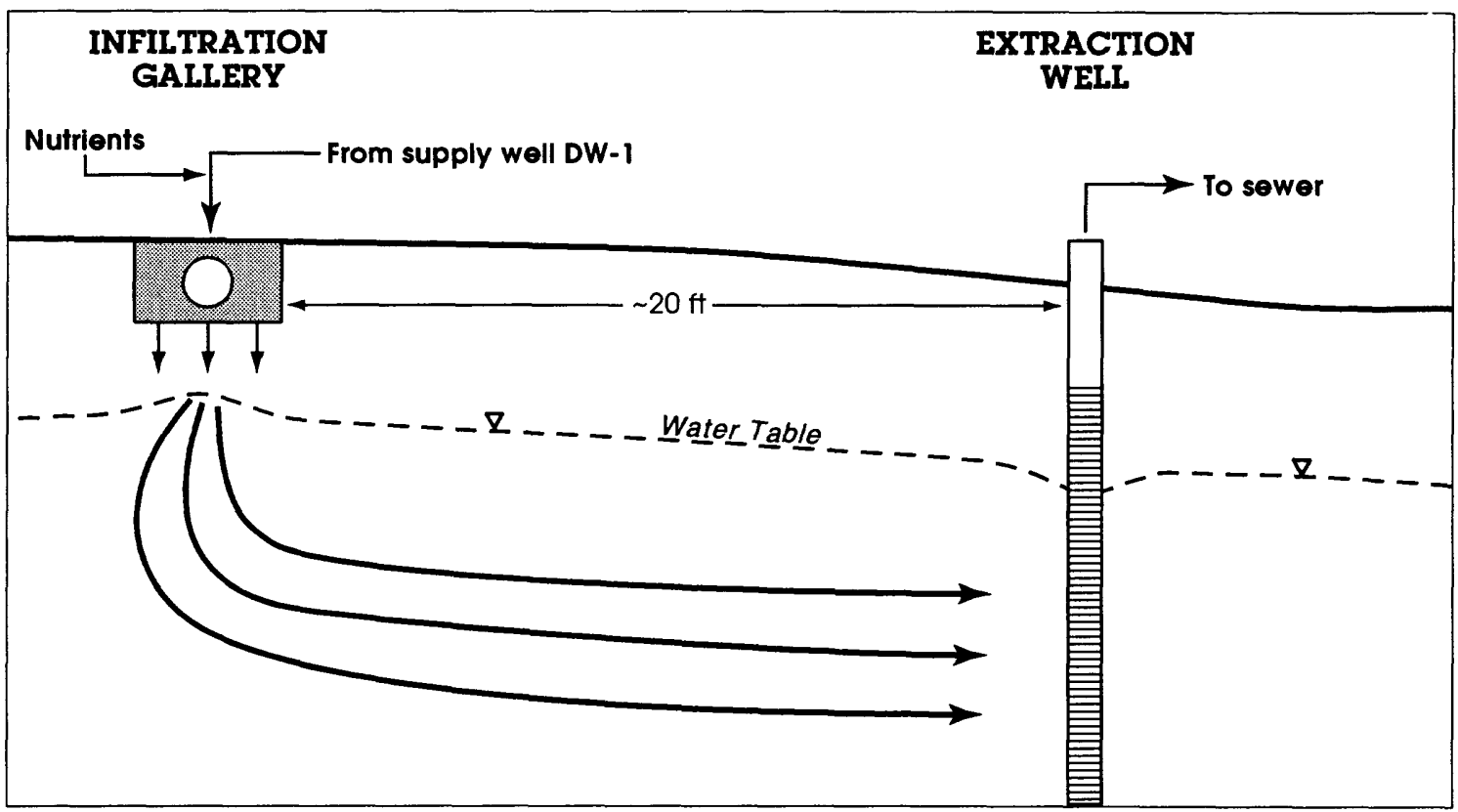

Figure 5. Hydraulic and bioremediation system, Defense Fuel Supply Point, Hanahan, S.C.

The engineered bioremediation system at the facility utilized infiltration galleries to inject electron acceptors into the contaminated aquifer. The uncontaminated water for engineered bioremediation was delivered to the surficial aquifer through a line of infiltration galleries (pl. 1). The line was divided into three sections, separated by gate valves. The three sections were identified as infiltration-galleries 1,2 , and 3 , and were north of the fuel storage tank numbers 1,2 , and 3 , respectively. Water delivery to individual infiltration galleries through separate feed lines (2-in. ID PVC) was controlled by globe valves in a splitter pit.

Each infiltration gallery consisted of an approximately 330 -ft length of 4 -in. diameter vitrified-clay pipe, at a depth of about $2 \mathrm{ft}$ bls. The pipe was perforated at angles of 45 degrees down from horizontal and was surrounded by packed gravel. Individual infiltration galleries were separated from adjacent galleries by 4 -in. gate valves. Each feed line intersected its respective infiltra- tion gallery at the approximate center. Distribution and metering boxes, identified as IG-1, IG-2, and IG-3 at the intersection of each respective infiltration gallery, allowed access to the injection water.

Although the original design of the system (RMT, Inc., 1989d) was to recirculate 60 percent of the water pumped out of the aquifer back through the infiltration galleries and discharge the remaining 40 percent to North Charleston Sewer District for subsequent treatment, the potential for system clogging by iron precipitation necessitated elimination of the recirculation aspect. Instead, all of the extracted water was sent to the North Charleston Sewer District, and injection water was derived from an uncontaminated onsite source.

The source for injection water was a production well, identified as DW-1, adjacent to the splitter pit (pl. 1). Well DW-1 was cased to a depth of $305 \mathrm{ft}$ bls and was an open hole from 305 to $381 \mathrm{ft}$ bls. The well was open to the Santee Lime- 
stone/Black Mingo aquifer beneath the dense 270-ft thickness of the Cooper Group/Cross Formation confining bed.

Water pumped from DW-1 was directed to the splitter pit where it was diverted to individual infiltration galleries at controlled flow rates. Water from DW-1 was introduced to the surficial aquifer through infiltration-gallery 2 from January 27 to February 4, 1992; June 12 to 22, 1992; October 7 to 9, 1992; October 21 to 24, 1992; November 20 to 26, 1992; April 27 to July 21, 1993; July 23 to 29, 1993; September 14 to 30 , 1993; and October 11, 1993 to September 30, 1995.

The ground water from well DW-1 was anaerobic and contained about $120 \mathrm{mg} / \mathrm{L}$ of sulfate as a potential electron acceptor. In the absence of more efficient electron acceptors (such as oxygen, nitrate, and $\mathrm{Fe}[\mathrm{III}]$ ), the presence of sulfate can allow sulfate-reducing conditions to dominate. Some monoaromatic compounds, such as toluene and xylenes, have been found to be microbially degraded under sulfate-reducing conditions (Holmer and Kristensen, 1994; Beller and others, 1992; Edwards and Grbic-Galic, 1992; Haag and others, 1991; Rabus and others, 1993); however, by adding oxygen and nitrate, the potential biodegradation efficiency can be increased by allowing the system to maintain oxic or nitratereducing conditions. Thus, the injection water to infiltration-gallery 2 was amended with nitrate to provide a more efficient electron acceptor. Low concentrations of DO entered the infiltration water during advective transfer of the water from the well to the infiltration gallery.

Sodium nitrate and sodium bromide solutions, 10 and 2 percent, respectively, were added to infiltration water from DW-1 using diaphragmtype chemical metering pumps. Bromide was added as a secondary conservative tracer to supplement the approximate $350 \mathrm{mg} / \mathrm{L}$ of chloride naturally present in the infiltration-gallery water. The additives were introduced to infiltration-gallery 2 through the feed line about $50-\mathrm{ft}$ downgradient from the splitter pit. The flow rates from the metering pumps were maintained at about
$8.0 \mathrm{~mL} / \mathrm{min}$ to provide target concentrations of $10 \mathrm{mg} / \mathrm{L}$ nitrate as nitrogen $(\mathrm{N})$ and $10 \mathrm{mg} / \mathrm{L}$ of bromide in the amended infiltration water. These injection rates were based on a constant flow rate of $4.5 \mathrm{gal} / \mathrm{min}$ from DW-1 to infiltration-gallery 2 . Because flow rates from DW-1 to infiltration gallery 2 could not be precisely maintained, unlike the flow rates from the metering pumps, actual concentrations of nitrogen and bromide introduced to the aquifer fluctuated slightly. Samples to determine the concentrations in the amended infiltration water were obtained at the distribution and metering box IG-2.

The infiltration water directed to infiltrationgallery 2 was amended with nitrate from May 21 to July 21, 1993; July 23 to July 29, 1993; September 14 to September 30, 1993; October 11, 1993 to January 12, 1994; and March 4 to September 23, 1994. During the period of nitrate amendment, approximately $60 \mathrm{mg} / \mathrm{L}$ as $\mathrm{NO}_{3}$ $(13.6 \mathrm{mg} / \mathrm{L}$ as $\mathrm{N})$ was allowed to infiltrate from infiltration-gallery 2 to the aquifer. By the time nitrate-amended water reached the extraction wells, the concentration of nitrate was about $33 \mathrm{mg} / \mathrm{L}$ as $\mathrm{NO}_{3}(7.5 \mathrm{mg} / \mathrm{L}$ as $\mathrm{N})$, as measured at well MWGS-33A. Low concentrations (approximately $14 \mathrm{mg} / \mathrm{L}$ ) of bromide were added to the infiltration water during the periods of nitrate amendment; however, bromide amendment continued during the period from January 12 to March 4, 1994, when nitrate amendment ceased.

After passing through the bioremediation piping system, the injection water contained an average DO concentration of $0.8 \mathrm{mg} / \mathrm{L}$. During times when the combined infiltration of rainwater and injection of slightly oxygenated water allowed oxic conditions to persist in the shallow aquifer, nitrate amendment was suspended. The temporary cessation of nitrate addition was intended to prevent potential accumulation of nitrate in the aquifer during times when aerobic respiration would limit nitrate reduction. 


\section{Hydraulic Remediation}

In addition to functioning as the nutrientdelivery mechanism for engineered bioremediation, the introduction of water from the infiltration galleries also functioned as part of the engineered hydraulic remediation system. Engineered hydraulic remediation refers to abiotic decreases in ground-water contamination resulting from introduction of uncontaminated water and advective removal of contaminated ground water. A total of about $5,155,000$ gal of water from DW-1 was introduced into the surficial aquifer through infiltration-gallery 2 at an average flow rate of about $4.2 \mathrm{gal} / \mathrm{min}$. Infiltration-gallery 1 received a total of about 20,000 gal of water from DW-1 between June 12 and June 22, 1992, at an average flow rate of about $1.3 \mathrm{gal} / \mathrm{min}$. Water rarely was discharged directly to infiltration-gallery 3 , and then only for short time periods (less than 1 day).

The ground-water extraction system consisted of 18 wells (pl. 1). Four of the wells (EW-01, EW-02, EW-03, and EW-04) were along the western boundary of the facility, eleven (EW-05, EW-06, EW-07, EW-08, EW-09, EW-10, EW-11, EW-12, EW-13, EW-14, and EW-15) along the northern boundary, two (EW-16 and EW-17) along the northeastern boundary, and one (EW-18) was in Gold Cup Springs subdivision.

Extraction-wells EW-01 through EW-17 were constructed with $30-\mathrm{ft}$ lengths of 6 -in. ID PVC slotted-screen sections (slot size 0.01 in.), placed to bracket the entire saturated thickness of the surficial aquifer. Because of the shallower depth to the botiom of the surficial aquifer in the subdivision, extraction-well EW-18 was installed with a $25 \mathrm{ft}$ screened section. Total depths of the wells ranged from $30 \mathrm{ft}(\mathrm{EW}-18)$ to $38 \mathrm{ft}$ (EW-06). The annular space from the bottom of the borehole to not less than $1 \mathrm{ft}$ above the top of the screened interval was filled with filter sand. A 1 - $\mathrm{ft}$ thick bentonite seal was placed above the sand pack, and the remaining annular space above the bentonite seal was grouted to land surface. Each wellhead was surrounded by a floored con- crete vault, the bottom of which was approximately $2 \mathrm{ft}$ bls.

A 0.5 -horsepower submersible pump capable of providing flow rates of about $10 \mathrm{gal} / \mathrm{min}$ was installed in each extraction well. The pumps were fitted with automatic level-control switches to deactivate and reactivate pump operation (cycling) to prevent dewatering the well. All extraction wells were connected to a common discharge pipe, through which all extracted ground water was directed offsite for treatment.

Extraction-wells EW-04 through EW-07 also were installed with skimmer pumps intended to recover free-phase petroleum. Because these skimmer pumps were installed in a fixed position with an operating range of $2 \mathrm{ft}$, it was difficult to maintain the water level in the wells within the range of operation. Consequently, little freephase petroleum was recovered. In an effort to recover greater volumes of product, the fixedposition skimmer pumps were replaced with depth-adjustable, hydrophobic skimmer pumps, capable of recovering free-phase petroleum from a greater range of water-level fluctuations. Hydrophobic skimmer pumps also were installed in wells EW-01, EW-02, and the 36-in. diameter recovery well. Plastic drums with overflow cutoff switches were installed in the well vaults to contain the extracted free-phase petroleum.

Continuous operation of the extraction system was initiated on January 27, 1992, with the activation of wells EW-09, EW-10, EW-11, and EW-18. Operation of wells EW-13 and EW-14 began on February 4, 1992, and continued until March 3, 1992. Well EW-13 began operating on March 11, 1992, and operated for about a week. Both wells operated from September 18 through 29, 1992, and from October 1 through December 1,1993 , when free product was detected immediately upgradient of EW-13 in well W-108. Subsequently, operation of well EW-13 was discontinued, and EW-14 was operated at low flow rates (average of about $1.6 \mathrm{gal} / \mathrm{min}$ ) to prevent induced migration of free product. Extraction wells EW-01 through EW-08 began continuous pumping on May 15, 1992. 
The continuous operation of extraction wells EW-03, EW-04, EW-15, EW-16, and EW17 was considered undesirable for various reasons. After pumping wells EW-03 and EW-04 for about three months, water-quality monitoring indicated that the continued operation of these two wells may be detrimental to the bioremediation system as a whole. Water from EW-03 was aerobic and relatively uncontaminated. The mixing of oxygenated water from EW-03 with anaerobic, Fe(II)-rich water from other extraction wells could have resulted in massive iron precipitation, which could have clogged the entire extraction system. Similarly, EW-04 was at an interface of aerobic and anaerobic waters and contained large amounts of iron precipitate. Wells EW-03 and EW-04 were turned off on August 25, 1992, and were not reactivated. Wells EW-15, EW-16, and EW-17 were not operated because of the potential to induce contaminant migration into areas previously containing little or no contamination.

Flow rates from the extraction wells could be controlled by adjusting valves on the discharge pipe at each wellhead. Initially, the system design called for the extraction wells to operate at a flow rate of approximately $3.4 \mathrm{gal} / \mathrm{min}$ each for wells EW-01 through EW-17, and approximately $6.8 \mathrm{gal} / \mathrm{min}$ for $\mathrm{EW}-18$, providing a total withdrawal rate from all 18 extraction wells of about $65 \mathrm{gal} / \mathrm{min}$ (RMT, Inc., 1991). Between January 27, 1992 and September 30, 1995, flow rates from on-site extraction wells varied, with typical flow rates between 1.5 and $3.5 \mathrm{gal} / \mathrm{min}$. The average flow rate from EW-18 during the period was approximately $2.4 \mathrm{gal} / \mathrm{min}$. In some instances, flow rates from wells near areas of free-phase petroleum were temporarily increased to as high as $6.0 \mathrm{gal} / \mathrm{min}$ to enhance hydraulic capture.

Total volumes of extracted water discharged to North Charleston Sewer District was measured at a totalizing flow meter in the splitter pit. Between January 27, 1992, when the extraction system was initially started, and September 30, 1995, a total of approximately $31,877,400 \mathrm{gal}$ of water had been removed from the surficial aquifer. Total daily flow rates during this period ranged from about $5,800 \mathrm{gal} / \mathrm{d}$ to about $49,700 \mathrm{gal} / \mathrm{d}$, with an average total daily flow rate of approximately $23,700 \mathrm{gal} / \mathrm{d}$.

\section{HYDROGEOLOGIC AND CHEMICAL FACTORS AFFECTING CONTAMINANT MOVEMENT AND REMEDIATION AT THE FACILITY}

Hydrogeologic and chemical factors in the aquifer at DFSP influenced the movement and remediation of ground-water contamination. The hydrogeologic factors included dilution and mobilization by rainfall recharge, seasonal changes in ground-water-flow directions, and aquifer heterogeneities. The chemical factors affecting contaminant biodegradation were those that influenced that amount and type of electron acceptor available for microbial use.

\section{Hydrogeologic Factors}

Rainfall infiltration had a variety of effects on the movement and concentration of the ground-water contamination. An example is well MWGS-32A. The concentration of toluene in the shallow ground water at well MWGS-32A decreased from $1,700 \mu \mathrm{g} / \mathrm{L}$ on April 24, 1992, to $190 \mu \mathrm{g} / \mathrm{L}$ on July 13,1992 , following a major recharge event. The event introduced sulfate (increase from 1.3 to $18 \mathrm{mg} / \mathrm{L}$ ) to ground water at the well, which allowed the TEAP to switch from methanogenesis (as suggested by the presence of $6.6 \mathrm{nM}$ hydrogen) to sulfate reduction (as suggested by the presence of $1.7 \mathrm{nM}$ hydrogen). This increase in efficiency of the TEAP probably increased biodegradation rates; however, the apparent decline in DIC concentrations (from $250 \mathrm{mg} / \mathrm{L}$ on April 8, 1992, to $77 \mathrm{mg} / \mathrm{L}$ on September 2, 1992) implied that dilution was the dominant factor in reducing contaminant concentrations.

Not all of the hydraulic effects of rainfall infiltration resulted in contaminant-concentration decreases, however. The residents of Gold Cup Springs subdivision complained of fuel odors following an unusually heavy rainfall in September 
1979 (U.S. Army Environmental Hygiene Agency, 1988). In May 1995, the USGS simulated a rainfall event by spraying uncontaminated water over the northern part of the tank 3 basin. The sprayed zone covered an area where freephase fuel contamination was present on the water table as well as an area where no free-phase fuel contamination was present in the saturated zone, but obvious petroleum contamination was present in the unsaturated zone. In the zone where no free-phase fuel contamination was present in the saturated zone, the BTEX concentration in ground water increased from about $400 \mu \mathrm{g} / \mathrm{L}$ prior to irrigation to about $1,500 \mu \mathrm{g} / \mathrm{L}$ when resampled 13 days following the initial irrigation. Thus, it appears that rainfall temporarily can dilute ground-water contaminant concentrations downgradient from source areas and can increase contaminant concentrations in ground water at the source areas where leachable contaminants are present in the unsaturated zone.

Seasonal differences in ground-water levels can change ground-water transport directions, particularly in the southern and northeastern parts of the facility (figs. 2 and 3 ) and also the locations of recharge and discharge areas in the stream immediately east of the facility (pl. 1). Periodic measurements of water levels in stream-bed piezometers along the axis of the stream bed showed that the stream contained both gaining and losing reaches. Moreover, the boundary between the gaining and losing reaches migrated upstream during periods of low ground-water levels and downstream during periods of high ground-water levels. During some periods of low ground-water levels, the stream was flowing adjacent to the facility but had disappeared by infiltration into the ground surface within a few hundred feet downstream from the facility. The significance of this is that the area of the stream adjacent to groundwater contamination at tank 3 and further upstream, west of tank 6 , is a gaining reach. Thus, there is a potential for ground-water contamination to discharge to the creek. Because the creek water infiltrates the creek bed further downstream, there is a potential that contamination dis- charging from ground water at the facility to the creek can then discharge from the creek to the aquifer further downstream.

The distribution of discontinuous clay or sandy-clay lenses beneath the facility also have important effects on contaminant mobility and depletion in parts of the study area. The lenses locally produce confined conditions. Along the northern boundary of the facility, clay and sandy clay lenses dominantly are present west of well MWGS-39 (fig. 4). In 1991, the USGS installed a series of observation wells north of tank 1 to determine whether the clay lenses beneath the water table at tank 1 had stratigraphically trapped petroleum-hydrocarbon contamination beneath the water table. Well MWGS-27A was screened at the water table (approximately $12.6 \mathrm{ft}$ bls in November 1991); well MWGS-27B was screened at a depth of 15.2 to $16 \mathrm{ft} \mathrm{bls,} \mathrm{immediately} \mathrm{below}$ the clay layer; and well MWGS-27C was screened at a depth of 21 to $22 \mathrm{ft} \mathrm{bls} \mathrm{(pl.} \mathrm{1).}$

When the wells were sampled in October 1991, the water-table well (MWGS-27A) contained about $500 \mu \mathrm{g} / \mathrm{L}$ of BTEX, and the deepest well (MWGS-27C) contained about $105 \mu \mathrm{g} / \mathrm{L}$ of BTEX. Well MWGS-27B, screened immediately below the clay, however, contained free-phase fuel (fig. 6). The water table was approximately 2 $\mathrm{ft}$ above the base of the clay at the time of sampling and approximately $4.3 \mathrm{ft}$ above the base of the clay during periods of heavy rainfall. The thickness of free-phase fuel in the aquifer was not determined because wells screened in a confined aquifer can function as collectors of product (Trimmell, 1987; Kimberlin and Trimmell, 1988).

The data from wells MWGS-27A-C indicated that part of the unrecovered jet fuel that leaked to the aquifer in 1975 had accumulated in a stratigraphic trap below the water table. As a result of this finding, an additional recovery effort was initiated, involving the installation of additional wells below the clay in the tank 1 basin. These and other wells in the area were sampled in May 1992, and analyses of these samples indicated that the jet fuel had not migrated to other 


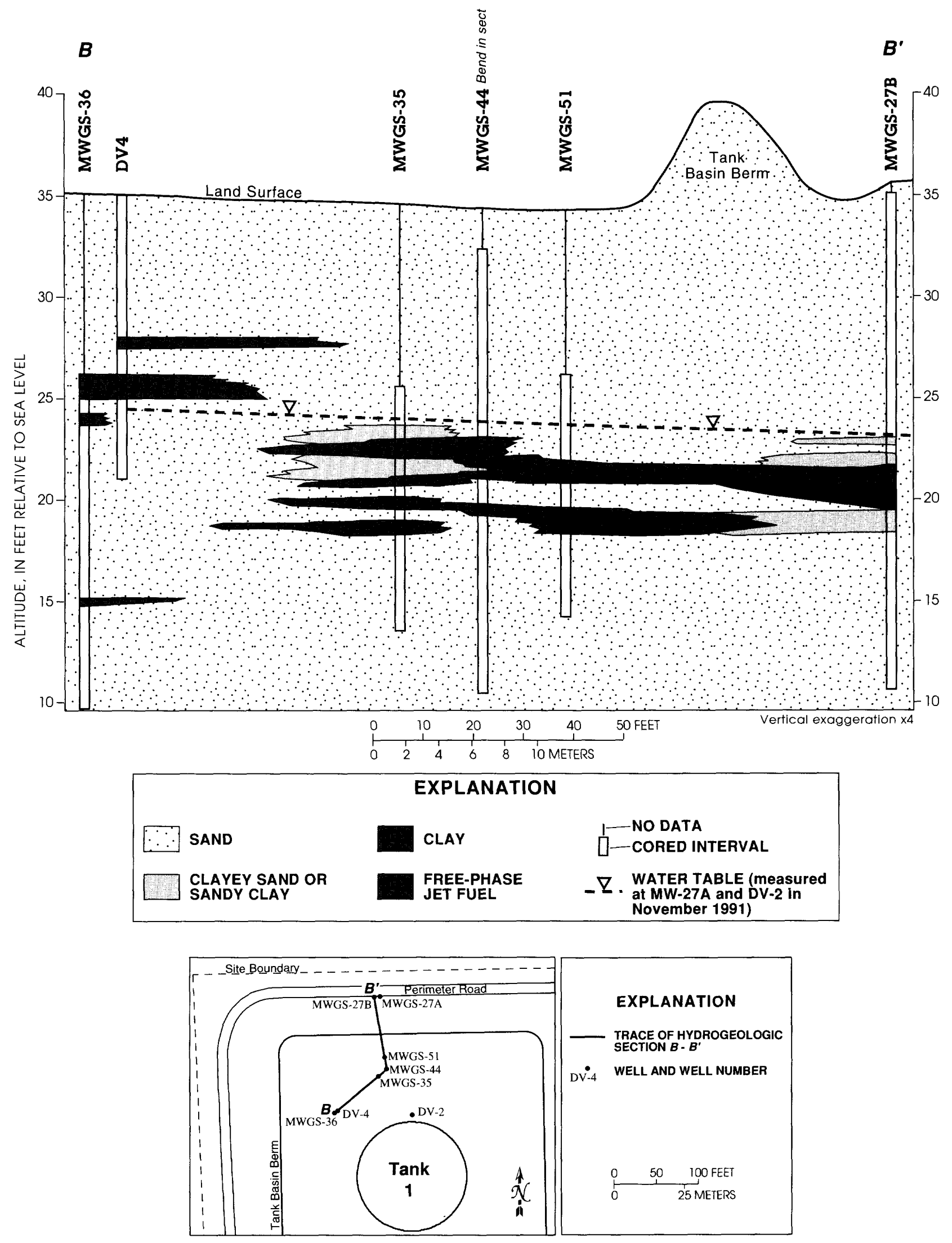

Figure 6. Hydrogeologic section $B-B^{\prime}$ in tank 1 basin showing approximate location of stratigraphically trapped free-phase jet fuel, Defense Fuel Supply Point, Hanahan, S.C. 
observation wells. Following start-up of the nearby extraction wells (EW-06 and EW-07), free-phase fuel began moving out of stratigraphic traps and toward the extraction wells (fig. 1).

The presence of stratigraphically trapped JP-4 means that the most contaminated horizon north of tank 1 is isolated from the influence of infiltration-gallery water. The isolation and apparent lack of significant weathering, as will be discussed in the next section, means that the fuel will continue to be a source of dissolved petroleum hydrocarbons until it is removed or otherwise remediated.

Free-phase jet fuel also was discovered in the tank 3 basin during this investigation. In December 1993, free-phase fuel began appearing in well W-108, north of the tank 3 basin. Delineation of the fuel showed that it extended from well W-108 into the tank 3 basin (fig. 1). The fuel had begun to migrate northwardly, possibly in response to the start-up of extraction-well EW-13, approximately two months earlier. Evaluation of the fuel by onsite personnel indicated that it was weathered JP-4 (Don Matthews, Defense Logistics Agency, oral commun., 1993).

\section{Chemical Factors}

The discovery of free-phase fuel stratigraphically trapped beneath the water table at tank 1 and shallow free-phase fuel not stratigraphically trapped at tank 3 allowed comparisons to be made between the two. The most obvious difference between the free-phase fuel at each site was the color. The JP-4 recovered from beneath clay layers at $\operatorname{tank} 1$ was amber colored, and the JP-4 recovered from the aquifer at tank 3 was black. The black color indicates that the tank-3 JP-4 was substantially more weathered than the tank-1 JP-4. Further evidence that the tank-3 JP-4 was more extensively weathered than the tank-1 JP-4 can be seen in the distribution of BTEX components in the ground-water contamination. At tank 1 , benzene is a dominant constituent of the ground-water contamination, but at tank 3 , toluene is the dominant constituent and benzene is only a minor constituent. Although some research has shown that the BTEX compounds can be transported at differing rates in ground water, resulting in chromatographic separation (Odermatt, 1994), the conditions at DFSP indicate that differential weathering was a primary factor. Benzene is readily biodegradable under aerobic conditions but under anaerobic conditions, it is substantially less biodegradable than toluene. Thus, at tank 3 , where recharge by infiltrating oxygenated rain water frequently delivered oxygen to the contamination, the free-phase fuel apparently was subject to extensive microbial degradation. The free-phase fuel at tank 1 was isolated from recharging oxygenated rain water by the presence of poorly permeable clay. Thus, the free-phase fuel at tank 1 apparently underwent little microbial degradation. These data also imply that without a mechanism to remove the trapped JP-4 or to deliver needed nutrients to the contaminated horizon, the free-phase fuel at tank 1 probably will continue to be a source of dissolved contamination for the foreseeable future.

Other constituents affected by microbial activity in the contaminated ground water included DO, Fe (II), sulfate, sulfide, hydrogen, methane, DIC, and low-molecular-weight aliphatic organic acids (formate, acetate, propionate, and butyrate). These compounds provided information that can indicate the predominant TEAP during microbial metabolism and are important because biodegradation rates can vary with different TEAP's. For example, Hutchins (1991) showed that biodegradation rates of toluene, $\mathrm{o}-\mathrm{xylene}$, and $\mathrm{m}$-xylene were faster under nitratereducing conditions than under sulfate-reducing conditions, and Mihelcic and Luthy (1988) showed that degradation of naphthalene and acenaphthalene was faster under denitrifying conditions than under anaerobic conditions in the absence of nitrate. Similarly, Smolenski and Suflita (1987) showed that the rate of biodegradation of several cresol isomers was faster under sulfatereducing conditions than under methanogenic conditions. These observations indicate that differences in anaerobic TEAP conditions directly 
affect microbial degradation rates of a variety of organic contaminants in ground water.

Dissolved oxygen typically was absent in contaminated parts of the aquifer. This is partly because microbial degradation of petroleum hydrocarbons rapidly depletes DO. An additional mechanism of DO depletion appears to be oxygen scavenging by dissolved $\mathrm{Fe}$ (II). As the predominant TEAP at wells MW-04 and MW-05 shifted from methanogenesis to iron reduction in January 1993 following a recharge event, a low concentration of DO $(0.08 \mathrm{mg} / \mathrm{L})$ was detected in the previously anaerobic ground water at nearby well MW06. Prior to January 1993, there was less Fe(II) (about 2 to $4 \mathrm{mg} / \mathrm{L}$ ) at well MW-06 than at wells MW-04 (about 17 to $20 \mathrm{mg} / \mathrm{L}$ ) or MW-05 (about 20 to $34 \mathrm{mg} / \mathrm{L}$ ). It appears that the amount of $\mathrm{Fe}(\mathrm{II})$ in the ground water at well MW-06 was insufficient to scavenge all of the DO introduced by the recharge. Thus oxidation of Fe(II) apparently is a mechanism that tends to buffer anaerobic conditions in the contaminated aquifer.

Vroblesky and Chapelle (1994) examined data from the site and reported that during times when little or no sulfate or oxygen was introduced to the ground water by recharge from rainfall or alternate sources, the available $\mathrm{DO}, \mathrm{Fe}(\mathrm{III})$, and sulfate could be depleted by respiring bacteria, leaving methanogenesis as the predominant TEAP. Nitrate was typically at low or undetectable concentrations except when added through the engineered bioremediation system. Introduction of oxygen, from rainfall infiltration, into the methanogenic parts of the aquifer could cause precipitation of $\mathrm{Fe}(\mathrm{III})$ as grain coatings. Once the oxygen was depleted, Fe(III)-reducing bacteria could take advantage of the precipitated $\mathrm{Fe}$ (III) to sequester most of the electron flow from degradation of organic compounds. If the water table was lowered below the zone of Fe(III) availability, electron flow could be sequestered by less efficient TEAP's, such as sulfate reduction.

Introduction of sulfate into a methanogenic part of the aquifer typically caused a shift in the predominant TEAP to sulfate reduction (Vroblesky and others, 1996). The rate of transition from methanogenesis to sulfate reduction varied across the study area. The transition was rapid ( $<10$ days) following recharge by infiltrating rainfall that increased the concentration of sulfate to about $30 \mathrm{mg} / \mathrm{L}$ at well MWGS-31A in January 1992. A substantially slower transition rate (about 3 months) was observed in a nearby part of the aquifer containing higher contaminant concentrations where the rainfall infiltration only increased the sulfate concentration to $2.6 \mathrm{mg} / \mathrm{L}$ (well MWGS-34B in January 1992).

Differences in TEAP's and in the amount of time needed to shift from one TEAP to another were observed over short horizontal $(<16.5 \mathrm{ft})$ and vertical $(<11.5 \mathrm{ft})$ distances (Vroblesky and Chapelle, 1994). The areal distribution of TEAP's across the site also varied. The data indicated that introduction of sulfate from recharge events or lateral transport could cause the predominant TEAP to shift from methanogenesis to sulfate reduction in large areas of the contaminated aquifer (fig. 7).

These changes in TEAP were important because biodegradation rates of a variety of organic contaminants have been shown to differ under differing TEAP's. The data suggested that during times when little or no sulfate and oxygen were being replenished to the aquifer by recharge or lateral transport, the least efficient metabolism of petroleum contaminants occurred in the most contaminated parts of the aquifer. The data also indicated that addition of alternate electron acceptors that are more microbially efficient than indigenous electron acceptors supplied by rainfall, or by engineering, could cause a shift in the aquifer to a more efficient TEAP, potentially increasing the biodegradation efficiency of a contaminated aquifer. This finding provides the basis for the engineered introduction of nitrate as a remediation alternative used in this investigation.

Several investigations have been published on the biodegradation of petroleum hydrocarbons under denitrifying conditions. Publications since 1990 include, but are not limited to, Evans and others (1991); Schocher and others (1991); Hutchins and Wilson (1991); and Gersberg and 
a

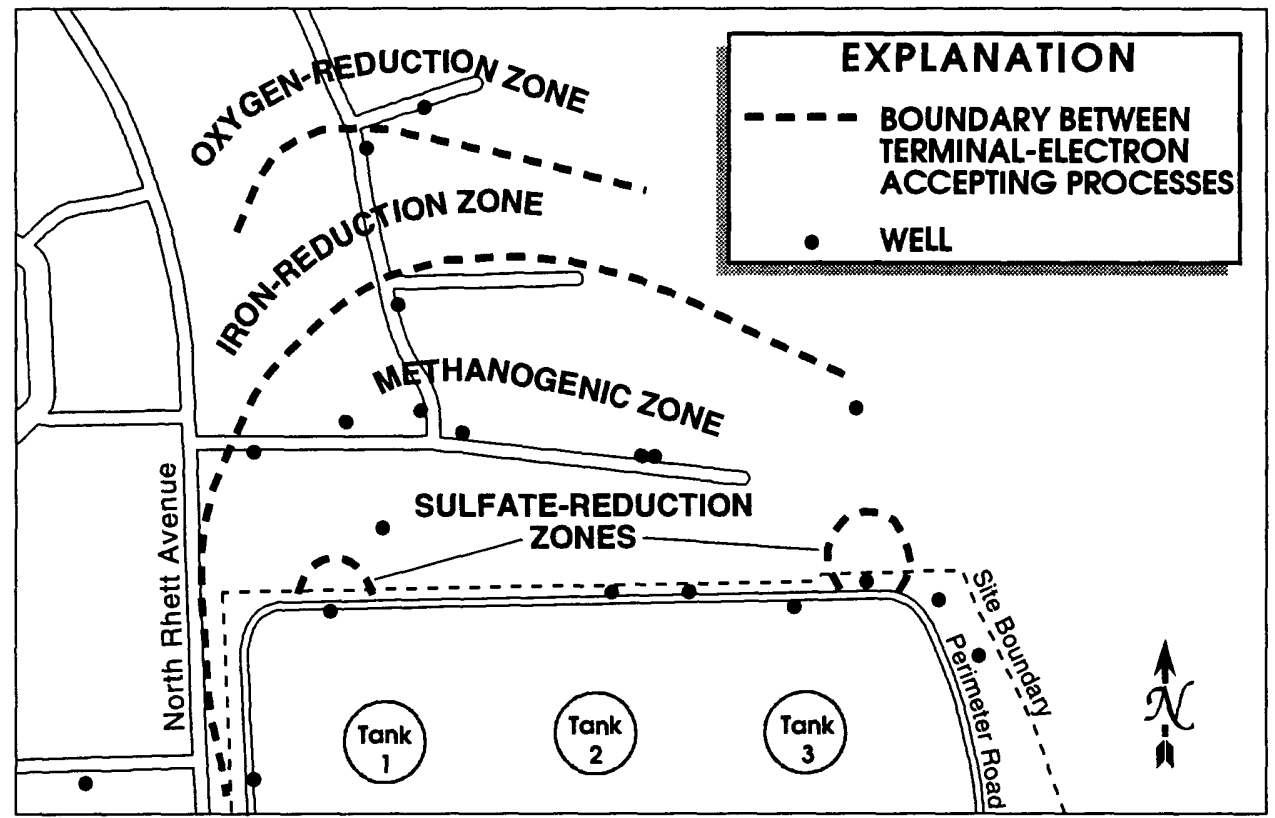

b

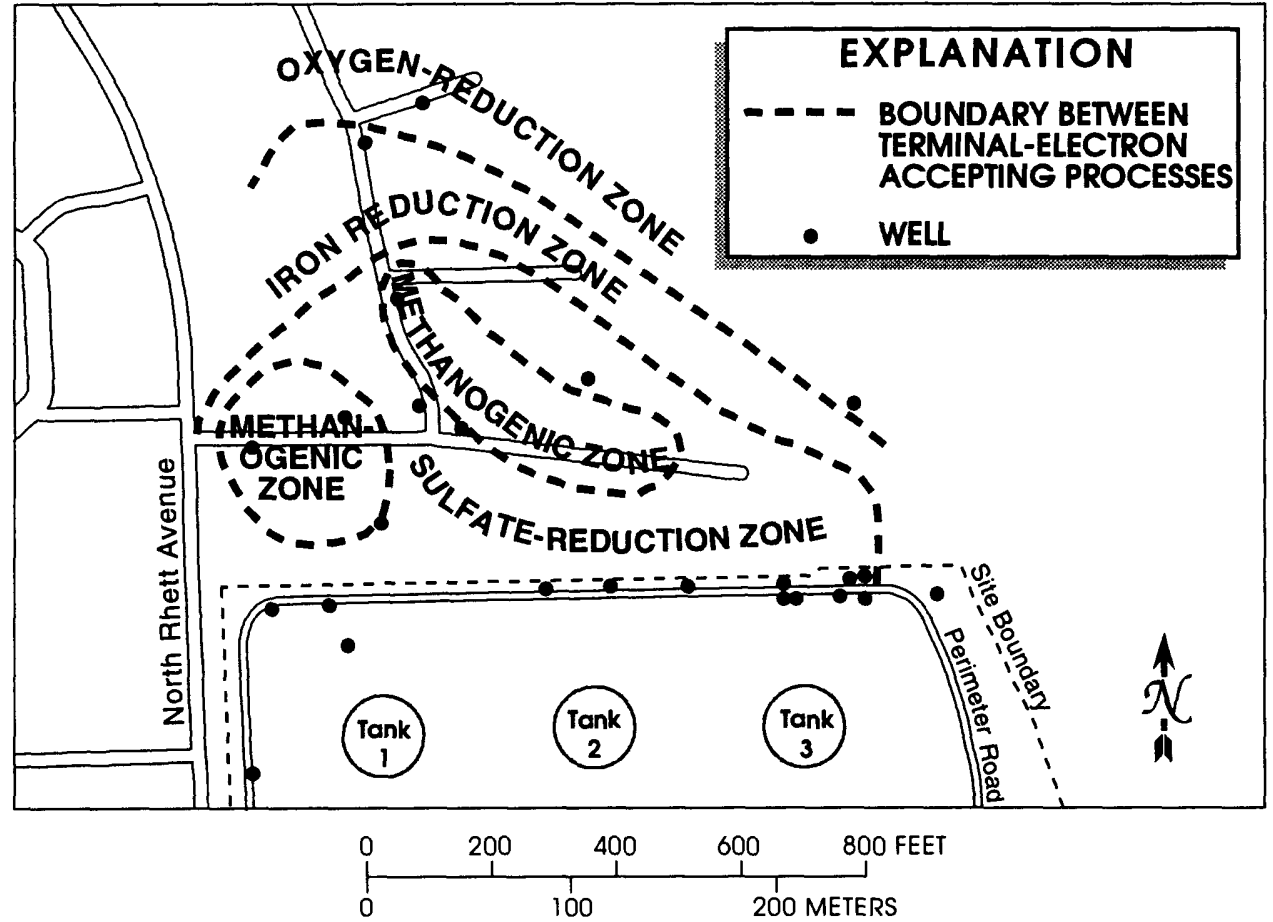

Figure 7. Areal distribution of terminal electron-accepting processes, based on interpretations of hydrogen measurements in ground water, Defense Fuel Supply Point, Hanahan, S.C., June 1991 (a) and November 1992 (b) (from Vroblesky and Chapelle, 1994). 
others $(1991 ; 1995)$. These investigations have shown that denitrifying bacteria can degrade toluene anaerobically, but cannot degrade benzene easily unless oxygen is present (Hutchins, 1991), and that biodegradation of xylene under denitrifying conditions was highly variable. Attributing the contaminant removal to microorganisms has been notoriously difficult because of complexities inherent in aquifer systems (Madsen, 1991), but a small number of studies have been able to provide evidence showing that denitrification can effectively enhance contaminant removal from aquifers (Berry-Spark and others, 1986; Sheehan and others, 1988; Hutchins and Wilson, 1991; Madsen, 1991; Gersberg and others, 1995).

\section{GROUND-WATER REMEDIATION IN THE NORTHERN PART OF THE FACILITY}

Ground-water remediation in the northern part of the facility was directed toward the plume emanating from the tank-1 basin, the plume emanating from near tank 3 and moving north and northwestwardly, and, to a lesser extent, the ground-water contamination west of tank 4 . The ground-water remediation included microbiologic and hydraulic controls. The addition of nutrientrich water to the aquifer north of tanks 2 and 3 provided a mechanism to enhance microbial degradation of the contamination, and extraction wells in the path of the contamination provided engineered hydraulic control. Nutrient-amended water was not added continuously to the contamination north of tank 1 because the most contaminated zone at that location was beneath a clay layer and not accessible by infiltration-gallerysupplied water.

Some onsite effects of remediation can be seen by comparing the areal distribution of BTEX north of tank 3 before and after initiation of the engineered remediation system. Immediately prior to operation of the extraction wells, concentrations of BTEX in the shallow part of the surficial aquifer (less than 17-ft depth bls) were greater than $1,000 \mu \mathrm{g} / \mathrm{L}$ north of tank 3 and greater than $100 \mu \mathrm{g} / \mathrm{L}$ northwest of the tank (fig. 8). Following operation of engineered hydraulic remediation and engineered bioremediation, the BTEX concentrations northwest of tank 3 decreased to less than $100 \mu \mathrm{g} / \mathrm{L}$ (fig. 9). The deeper part of the surficial aquifer (about 16-30 ft bls) was below the zone affected by the nutrientamended infiltration-gallery water and little change in concentrations was noted. Extractionwell EW-13 was not in operation during much of this investigation because of the potential to induce unwanted transport of nearby free-phase fuel; consequently, the BTEX concentrations in the deeper part of the surficial aquifer near well EW-13 (wells MWGS-32B and MWGS-33B) increased (figs. 10 and 11).

\section{Bioremediation}

Bioremediation of contaminated ground water along the northern side of the facility included both natural and engineered aspects. Natural bioremediation is defined as the microbial degradation of organic compounds in the aquifer without the engineered addition of nutrients (electron acceptors). In natural bioremediation, microbial populations utilized electron acceptors that were present in the aquifer water or sediments or were delivered to the aquifer by rainfall infiltration. The engineered approach at this site was the delivery of electron acceptors to the aquifer by injection of nutrient-rich water to the aquifer through infiltration galleries. Evidence that the subsurface microbes degraded petroleum-hydrocarbon contamination at the facility can be seen in laboratory and field data.

\section{Laboratory Evidence}

The laboratory evidence indicating that the subsurface microbes at the facility degraded petroleum hydrocarbons came from a series of studies initiated early in this project. The laboratory studies were designed to determine the bioremediation potential at the facility. Using sediment from the facility, the first laboratory 


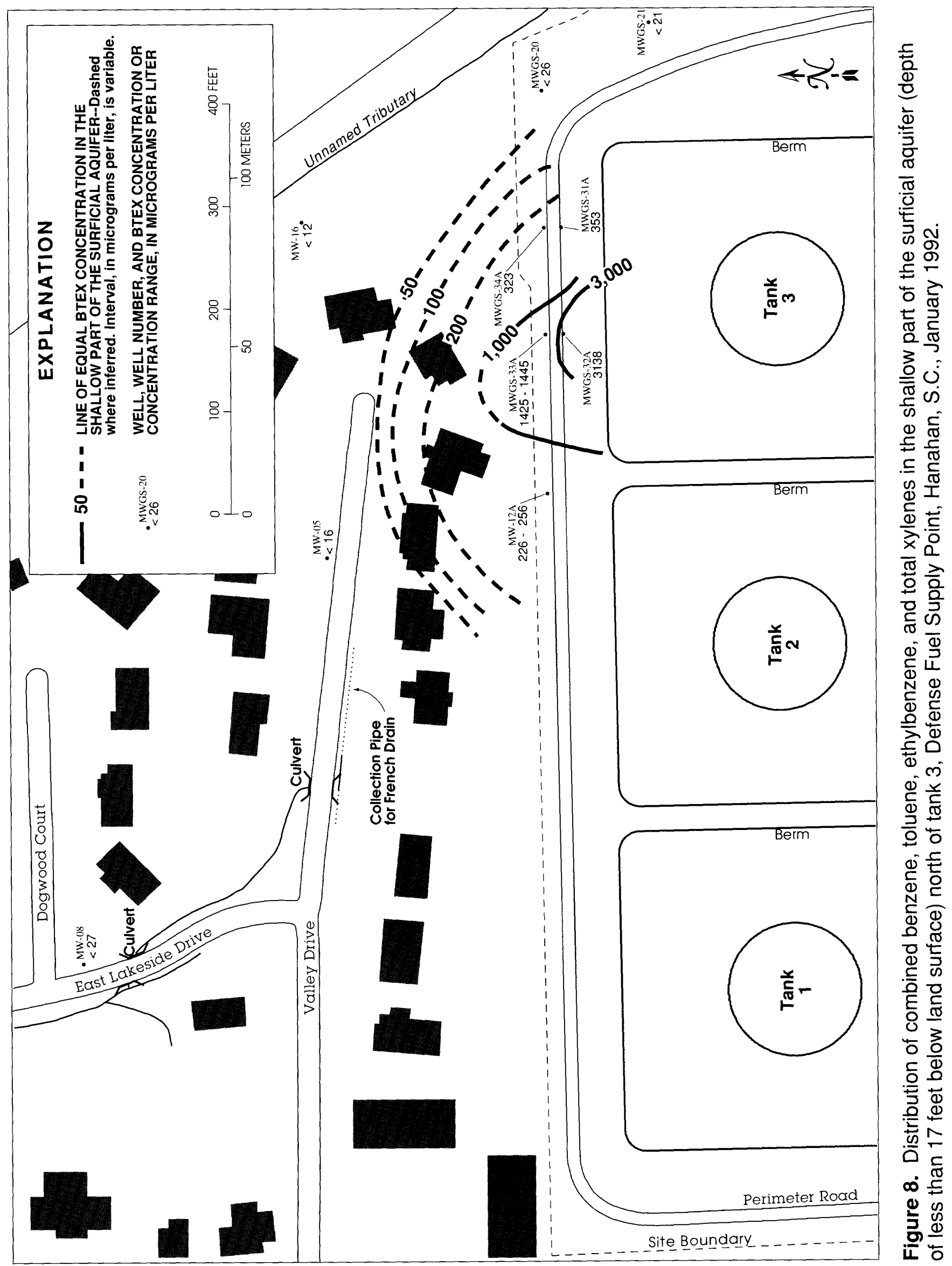

26 Remediation of Petroleum Hydrocarbon-Contaminated Ground Water in the Vicinity of a Jet-Fuel Tank Farm, Hanahan, South Carolina 


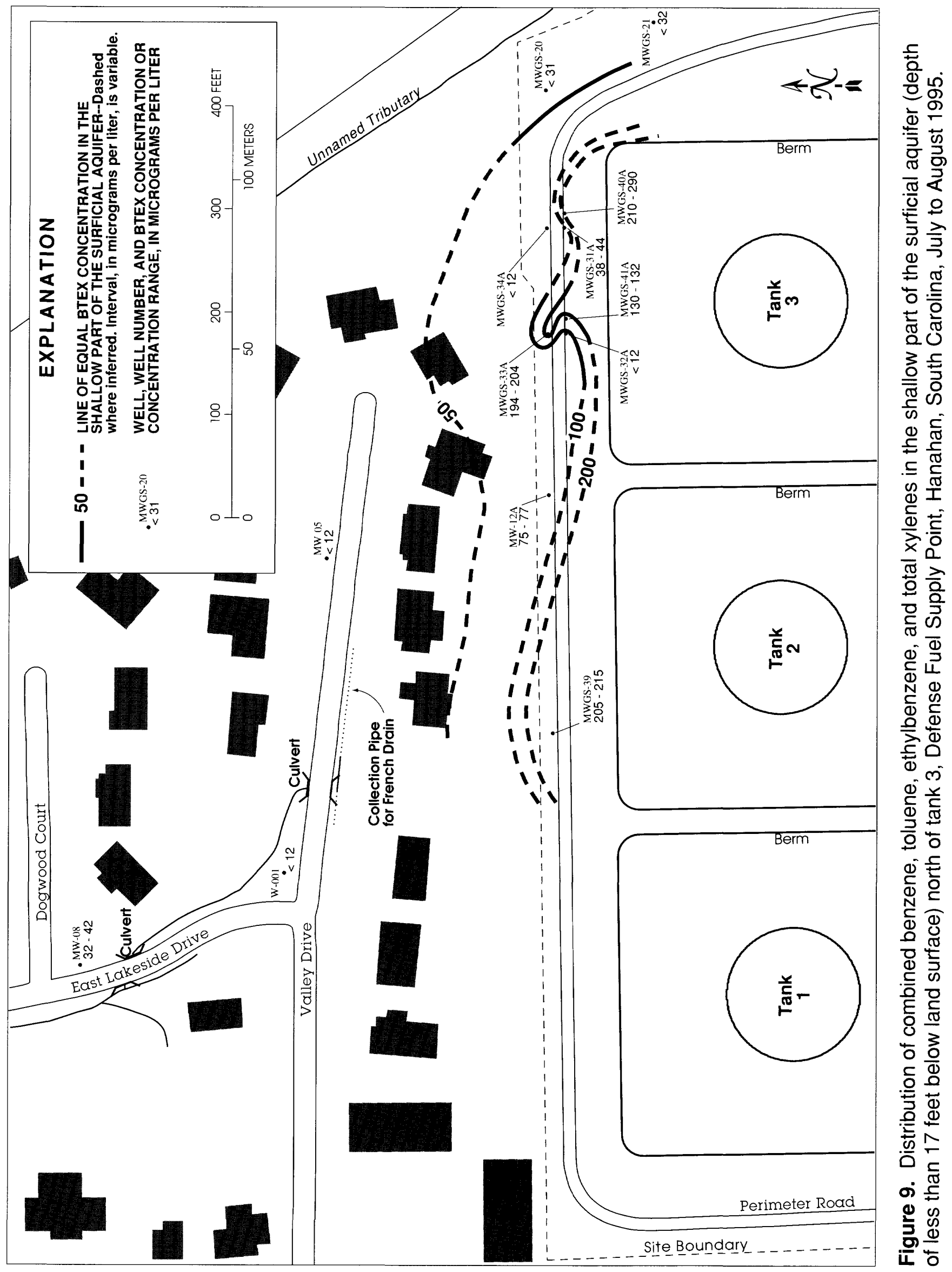




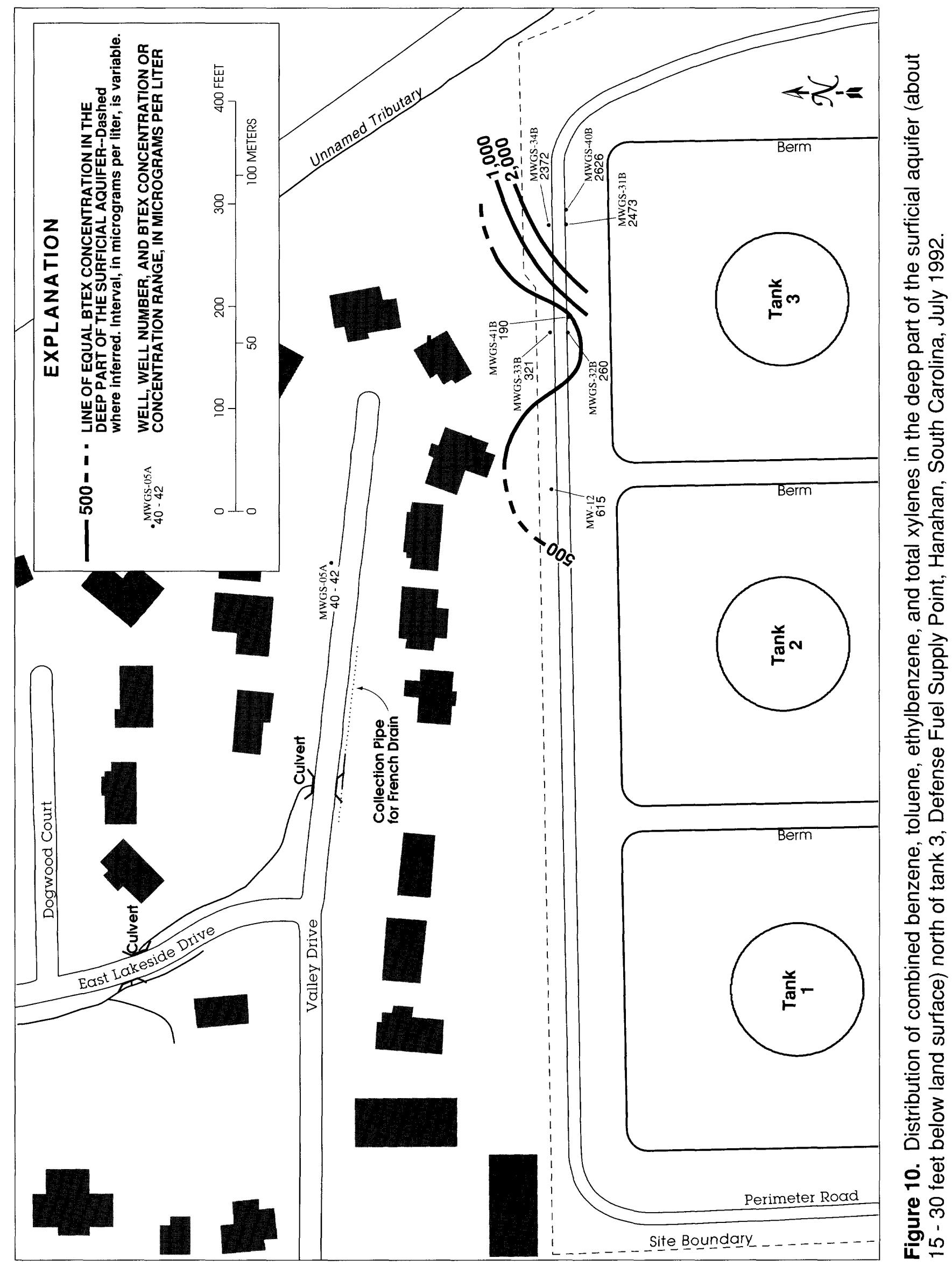

28 Remediation of Petroleum Hydrocarbon-Contaminated Ground Water in the Vicinity of a Jet-Fuel Tank Farm, Hanahan, South Carolina 


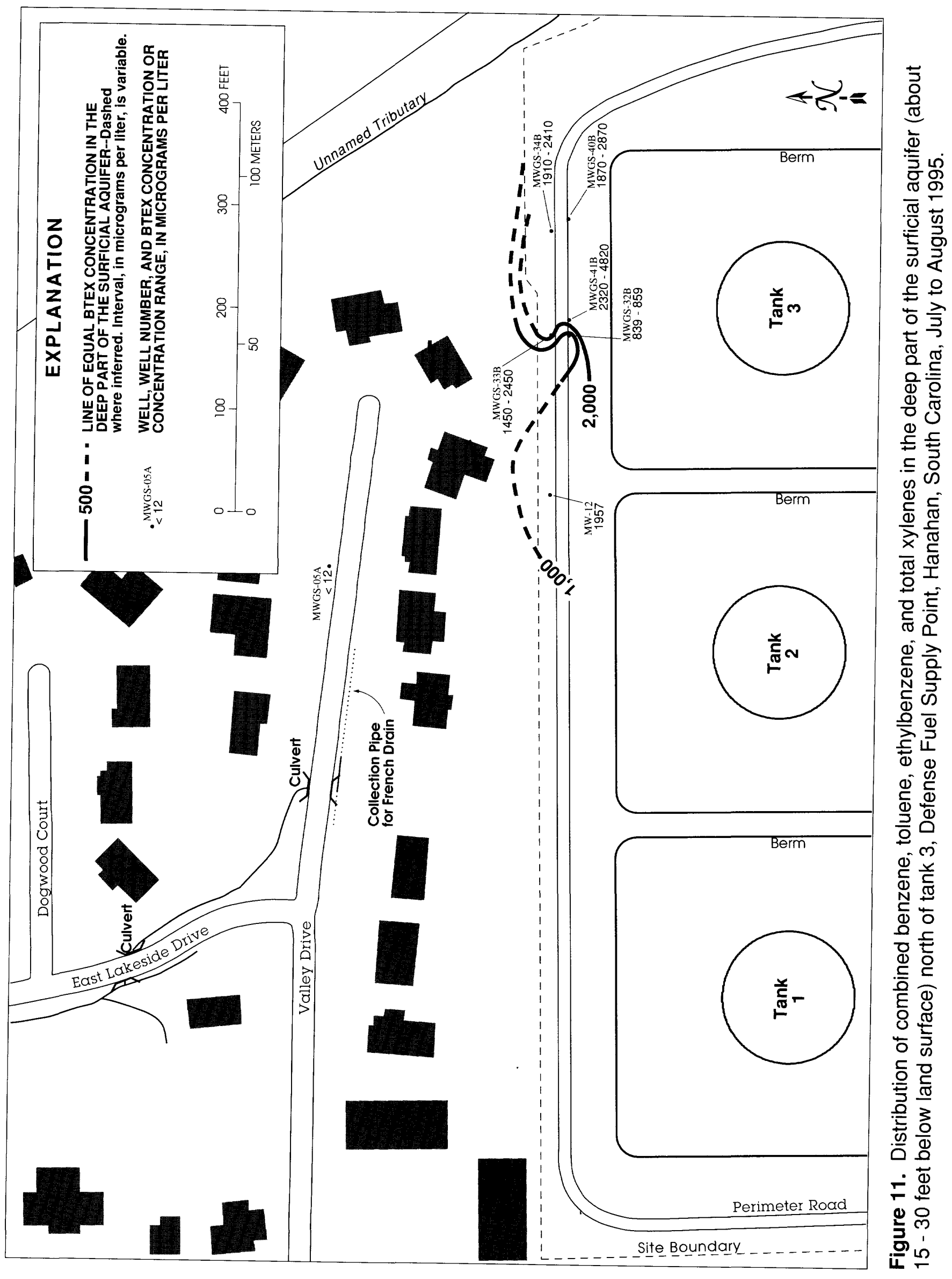


study reported significant carbon dioxide $\left(\mathrm{CO}_{2}\right)$ production under anaerobic and aerobic conditions, indicating that the indigenous bacteria were capable of JP-4 degradation (F.H Chapelle, U.S. Geological Survey, written commun., 1988). The same study showed that bacterial populations in contaminated areas were more acclimated to JP-4 utilization than those in uncontaminated areas. Adding nitrate to the microcosms did little to improve aerobic degradation, but substantially improved anaerobic degradation.

Further laboratory studies (Aelion and Bradley, 1991; Bradley and others, 1992) using sediment from the facility confirmed that the subsurface microorganisms at the facility were capable of degrading some components of the contamination. The studies showed that the indigenous microbes from the contaminated sediments had acclimated to the contamination and remained active despite the potentially toxic effects of JP-4. The investigations concluded that the reason nitrate addition substantially improved anaerobic degradation in the previous study was because insufficient nitrate was present in the aquifer to allow the subsurface microbial community to maintain nitrate reduction.

\section{Field Evidence}

Field evidence from the facility supported the laboratory evidence that the native microbial community was capable of degrading petroleum contamination with increased efficiency if nutrients were added to the aquifer. The nutrients were added to the aquifer by recharge water from infiltration-gallery 2. Well EW-11, screened in contaminated ground water approximately $20-\mathrm{ft}$ downgradient from infiltration-gallery 2 , provides an example of engineered bioremediation.

Prior to December 13, 1993, the anaerobic ground water at well EW-11 contained an average of $130 \mu \mathrm{g} / \mathrm{L}$ of toluene (fig. 12A), $170 \mu \mathrm{g} / \mathrm{L}$ of ethylbenzene (fig. 12A), and $460 \mu \mathrm{g} / \mathrm{L}$ of total xylenes (Petkewich and others, in press) (average of 14 samples collected from February 17 to November 18, 1993). Benzene concentrations were low and often less than $20 \mu \mathrm{g} / \mathrm{L}$. Although low concentrations of nitrate from infiltrationgallery $2\left(0.08\right.$ to $0.14 \mathrm{mg} / \mathrm{L}$ as $\left.\mathrm{NO}_{3}\right)$ began showing up in the ground water at well EW-11 by October 13, 1993, nitrate arrived at well EW-11 in an appreciable amount $\left(12 \mathrm{mg} / \mathrm{L}\right.$ as $\left.\mathrm{NO}_{3}\right)$ between November 18 and December 13, 1993 (fig. 12B).

With the arrival of nitrate at well EW-11, by December 13, 1993, contaminant concentrations in the ground water at the well sharply decreased. Between November 18 and December 13, the toluene concentration declined from 76 to less than $20 \mu \mathrm{g} / \mathrm{L}$ (fig. 12A), the ethylbenzene concentration declined from 230 to $45 \mu \mathrm{g} / \mathrm{L}$ (fig. 12A), and the total xylene concentrations declined from 650 to $130 \mu \mathrm{g} / \mathrm{L}$ (Petkewich and others, in press). These declines cannot be attributed to simple dilution. The chloride concentration at well EW-11 was about the same on August 4, 1993 $(89 \mathrm{mg} / \mathrm{L})$, as on December 13, $1993(83 \mathrm{mg} / \mathrm{L})$ (fig. 12B), suggesting that the amount of dilution from infiltration-gallery water was similar on both dates. However, the toluene, ethylbenzene, and total xylene concentrations were substantially lower on the second date. The major geochemical difference was the presence of nitrate on December 13, 1993 (fig. 12B). In addition, the $\mathrm{NO}_{3} / \mathrm{Cl}$ molar ratio in ground water at well EW-11 (0.085) on December 13 was lower than in the injection water $(0.093)$, indicating a loss of nitrate. By January 11,1994 , the $\mathrm{NO}_{3} / \mathrm{Cl}$ ratio in ground water at well EW-11 $(0.012)$ was still lower than in the injection water $(0.069)$ indicating additional loss of nitrate. These data strongly suggest that the engineered addition of nitrate to the ground water allowed the microbial community at well EW-11 to initiate nitrate reduction and that microbial degradation under nitrate-reducing conditions contributed to the toluene, ethylbenzene, and total xylene depletion.

Additional evidence that the contaminants were being degraded by the microbial community at well EW-11 can be seen in the increase in DIC concentrations. Biodegradation of BTEX compounds in an aquifer contributes carbon dioxide to the ground water, which is reflected as DIC. 

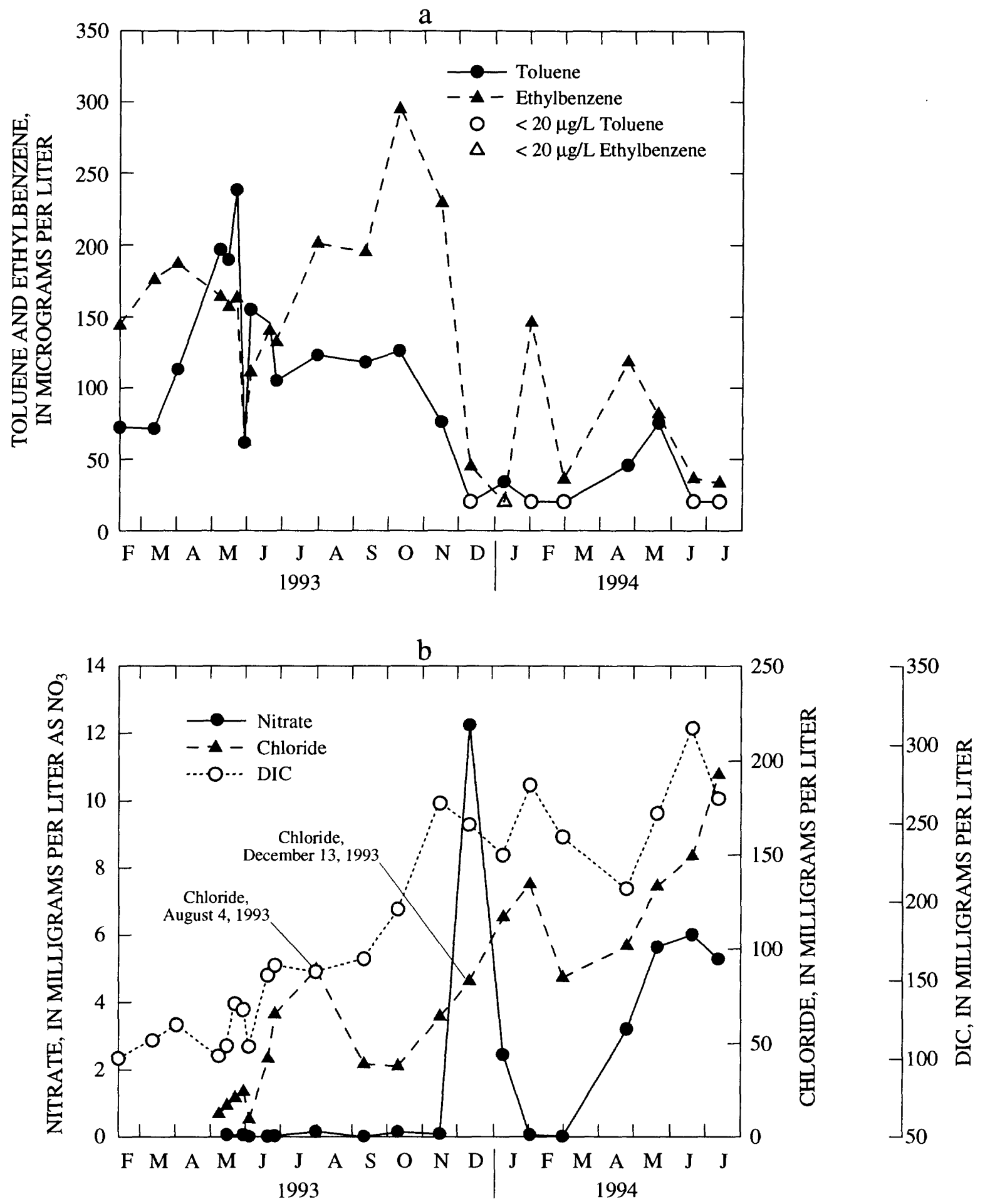

Figure 12. Ground-water chemistry at well EW-11, Defense Fuel Supply Point, Hanahan, S.C., 1993-94. 
Although similar amounts of dilution from infiltration-gallery water existed at well EW-11 on August 4 and December 13, 1993, the DIC concentration was higher on the second date (fig. 12B). In fact, the DIC concentration had been increasing since August 4, despite the temporary cessation of water infiltration at infiltration-gallery 2 between July 22 and October 11, 1993. Thus, the DIC concentration increase on those dates was not caused by the input of DIC from infiltration-gallery water. The implication is that introduction of nutrients increased biodegradation rates.

A general decline in ground-water contaminant concentrations at well EW-11 continued after December 18, 1993 (fig. 12A). During the period of nitrate addition between December 18, 1993, and July 14, 1994, the eight samples collected showed an average toluene concentration of $30 \mu \mathrm{g} / \mathrm{L}$, an average ethylbenzene concentration of $64 \mu \mathrm{g} / \mathrm{L}$, and an average total xylene concentration of $200 \mu \mathrm{g} / \mathrm{L}$. In later months (August 23, 1994 to September 27, 1995) the concentrations continued to decline. The twelve samples collected during this time period showed an average toluene concentration of $11 \mu \mathrm{g} / \mathrm{L}$, an average ethylbenzene concentration of $47 \mu \mathrm{g} / \mathrm{L}$ and an average total xylene concentration of $88 \mu \mathrm{g} / \mathrm{L}$. Increases in chloride concentration following December 18, 1993, however, suggested that dilution eventually became a contributing factor leading to contaminant depletion at well EW-11 (fig. 12B).

The effects of engineered bioremediation also can be seen in ground water at other wells in the northern part of the facility. Data from wells MW-12 and MW-12A show that both the operation of extraction wells and the injection of infiltration-gallery water enhanced aquifer bioremediation. Wells MW-12 and MW-12A are adjacent to each other but screened at different depths, approximately $45 \mathrm{ft}$ east of well EW-11 (pl. 1). Following start-up of well EW-11 on January 27, 1992 , and prior to injection of infiltration-gallery water, the concentrations of toluene, ethylben- zene, and total xylenes in ground water at well MW-12 decreased.

The data suggested that not all of the contaminant depletion at well MW-12, deepest of the pair, was due to advective capture by EW-11. The ground-water chemistry at well MW-12 suggested that biodegradation efficiency increased in the aquifer following start-up of well EW-11. In the ground water at well MW-12, the concentration of toluene, a readily biodegradable compound, declined from greater than $1,400 \mu \mathrm{g} / \mathrm{L}$ prior to operation of well EW-11 to less than $250 \mu \mathrm{g} / \mathrm{L}$ by April 1992 and remained below $250 \mu \mathrm{g} / \mathrm{L}$ during June, July, and September (fig. 13A). The concentrations of benzene and total xylenes, however, did not similarly decrease (fig. 13B), as would be expected if advective removal were the only depletion mechanism. These data imply that biodegradation was a depletion mechanism for toluene.

Effects of the engineered bioremediation can be seen at well MW-12A following start-up of the infiltration gallery. Although it is clear that injected water was reaching the screened interval at well MW-12A by June 30,1993, based on chloride concentrations (fig. 14A), nutrient concentrations in the anaerobic ground water at well MW-12A were substantially below injectate concentrations. Nitrate typically was absent at well MW-12A $(<0.01 \mathrm{mg} / \mathrm{L})$ during the period of nitrate injection (Petkewich and others, in press). The only nitrate measured was $0.09 \mathrm{mg} / \mathrm{L}$ on October 13,1993 . In addition, $\mathrm{SO}_{4} / \mathrm{Cl}$ ratios at well MW-12A were substantially lower than in the injection water (fig. 14A). Thus, nitrate and sulfate in the injection water were being depleted in the aquifer along the flowpath between the infiltration gallery and well MW-12A. The most probable explanation is that they were depleted by microbial reduction coupled to organic contaminant biodegradation. Support for this hypothesis can be seen in the lack of measurable toluene concentrations following injection of nutrient-amended water (fig. 14B). Thus, the decreases in contaminant concentration at well 

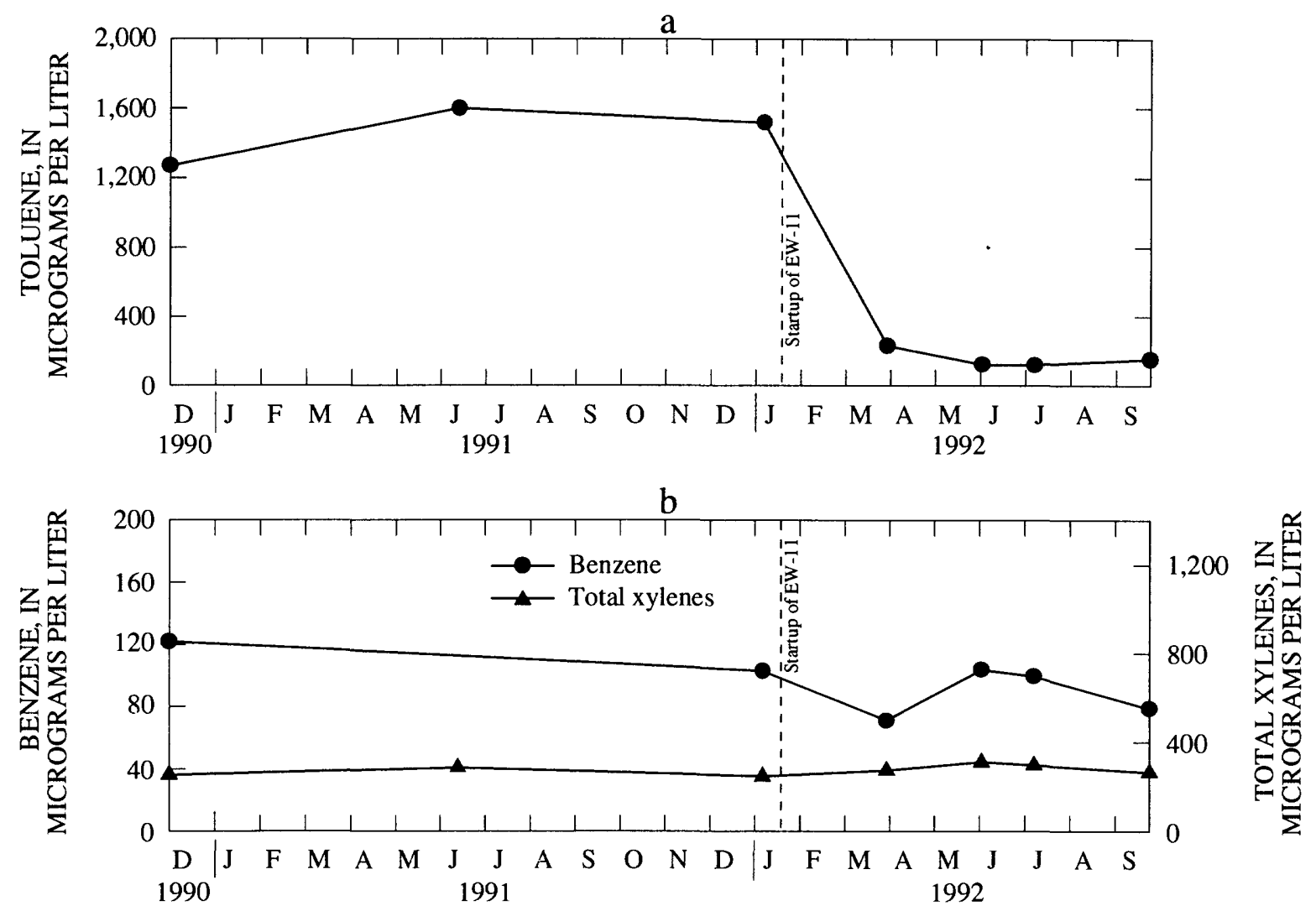

Figure 13. Toluene (a), and benzene and total xylene (b) concentrations in ground water at well MW-12, Defense Fuel Supply Point, Hanahan, S.C., 1990-92.

MW-12A following start-up of infiltration-gallery 2 appeared to be partly due to enhanced microbial degradation.

The ground-water contamination north of tank 3 also was affected by injectant water from infiltration-gallery 2 . A leak in the separation valve between infiltration-galleries 2 and 3 allowed nitrate-amended water to enter infiltration-gallery 3 and discharge to the ground water in the vicinity of wells MWGS-32A and MWGS$33 \mathrm{~A}$ (pl. 1). Because increases in nitrate, oxygen, sulfate, and chloride concentrations were detected in ground water from these wells at approximately the same time (Petkewich and others, in press), the contaminant-depletion mechanism cannot be easily differentiated. The arrival time of injection water at well MWGS-33A is represented by the increase in specific conductance during late August 1993 and again during November 1993 (fig. 15). The arrival date at well MWGS-32A probably was slightly sooner (less than a month) than at well MWGS-33A. Despite the uncertainty regarding the specific removal mechanism of the contamination, it is clear that contaminant concentrations markedly decreased during the engineered remediation. The toluene concentration decreased from greater than $100 \mu \mathrm{g} / \mathrm{L}$ at well MWGS-33A (fig. 15A) and greater than $700 \mu \mathrm{g} / \mathrm{L}$ at well MWGS-32A (fig. $15 \mathrm{~B})$ prior to injecting water to typically less than $2 \mu \mathrm{g} / \mathrm{L}$ at each well after injection.

Well MWGS-41A (pl. 1) also received injection water from the infiltration gallery. In the months prior to injection, the toluene concentration in ground water at well MWGS-41A ranged from 560 to $2,800 \mu \mathrm{g} / \mathrm{L}$ (fig. 16A). Following a short-lived injection of infiltration-gallery water in late July 1993, as reflected in specific conductance readings at nearby well MWGS-33A (fig. 15A), the concentration of toluene decreased from 2,500 to $330 \mu \mathrm{g} / \mathrm{L}$. By the next sampling, amended water was entering the aquifer continuously, as noted by the increase in chloride concentration (fig. 16B), and the toluene concentration declined to $<2 \mu \mathrm{g} / \mathrm{L}$ (fig. 16A). 

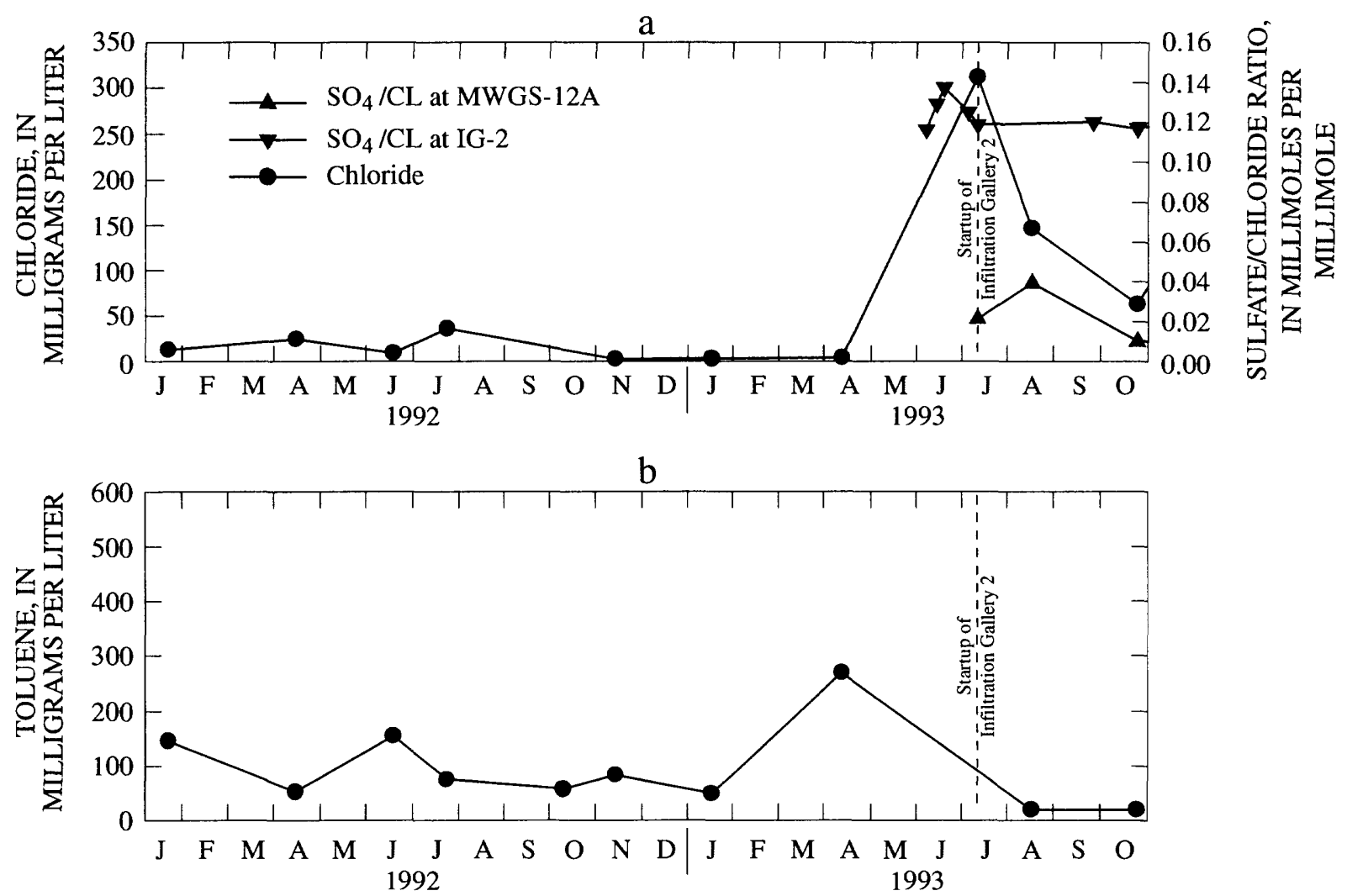

Figure 14. Chloride concentrations and sulfate/chloride ratios (a), and toluene concentrations (b) at well MW-12A, Defense Fuel Supply Point, Hanahan, S.C., 1992-93.

Although much of the toluene loss at well MWGS-41A probably was due to dilution effects, microbial populations appear to have been active as well. During the period of continuous injection from December 1993 to January 1995, DO was present in the ground water at MWGS-41A (fig. 16C). During that period, the ratios of $\mathrm{SO}_{4} / \mathrm{Cl}$ in the aquifer at well MWGS-41A were similar to or higher than the $\mathrm{SO}_{4} / \mathrm{Cl}$ ratios in the injection water (fig. 16C), indicating no loss of sulfate along the flowpath from the injection gallery to the well (about $3 \mathrm{ft}$, horizontally). Once the aquifer became anaerobic, however, the ratio in ground water decreased to values less than in the injection water (fig. 16C), implying a depletion of sulfate along the ground-water flowpath. This is consistent with a microbial population switching from aerobic respiration to anaerobic sulfate reduction.

\section{Hydraulic Remediation}

Hydraulic remediation at the facility consisted of engineered and natural controls on the amount of water entering and leaving the contaminated aquifer. Controls on the natural hydraulic remediation of the ground-water contamination were discussed earlier. Through engineered controls, solute-transport pathways were altered, allowing extraction wells to act as collection points for the removal of ground-water contamination.

An example of engineered hydraulic remediation can be seen in the mobilization and capture of stratigraphically trapped free-phase fuel. Prior to initiating the operation of the extraction wells, the free-phase fuel stratigraphically trapped beneath the water table north of tank 1, appeared to be relatively immobile (fig. 6). Because it had remained undetected for approximately 17 years, it had been a long-term source of dissolved BTEX contamination in the ground-water north of tank 1.

In an effort to mobilize and recover the stratigraphically trapped fuel, extraction wells 

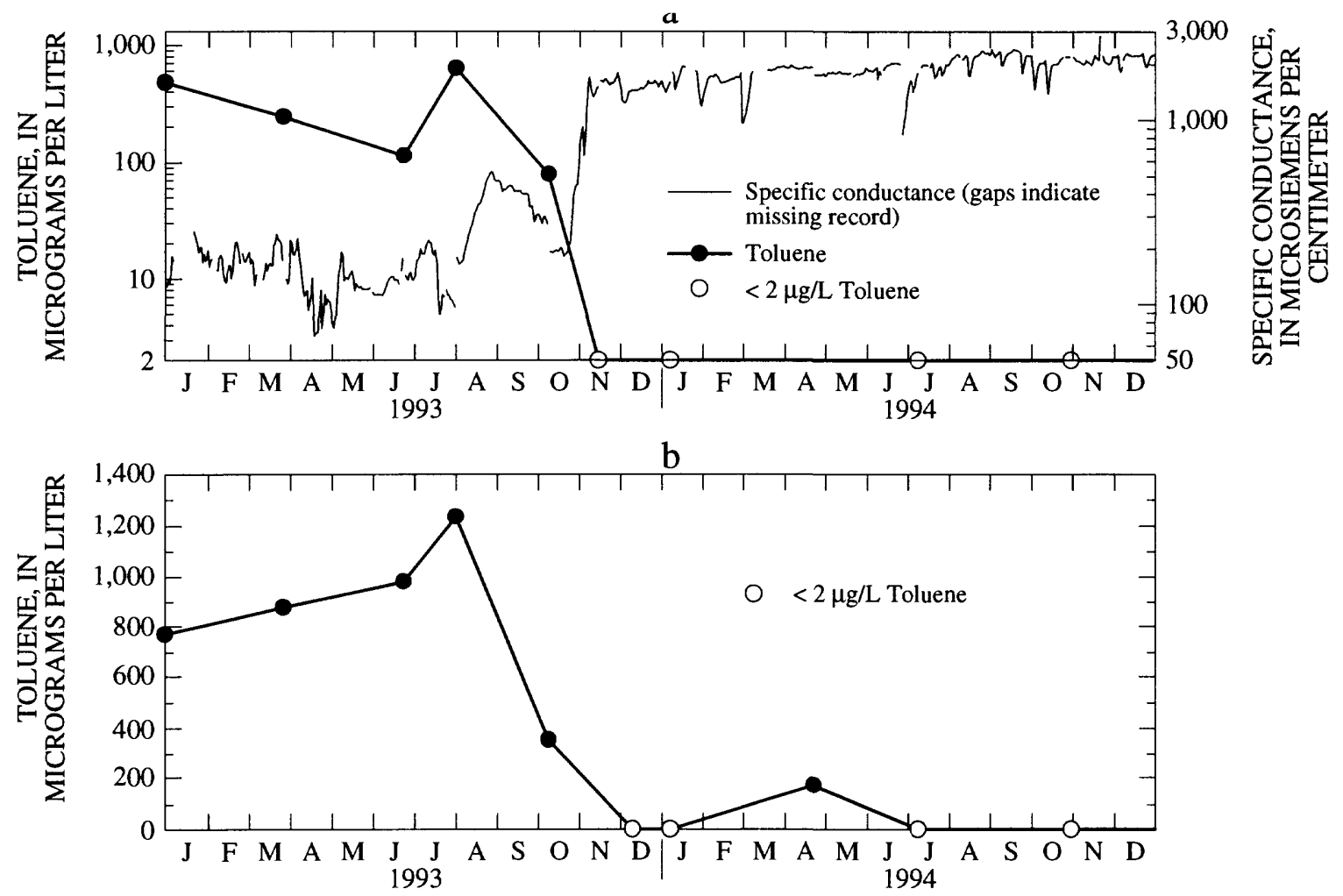

Figure 15. Toluene concentrations at wells MWGS-33A (a) and MWGS-32A (b), and specific conductance at well MWGS-33A (a), Defense Fuel Supply Point, Hanahan, S.C., 1993-94.

north of the fuel were turned on, and contaminated ground water was pumped offsite to a treatment facility. The extraction wells initially contained no free-phase fuel, but by August 1992, free-phase fuel began appearing in extraction wells and other observation wells (W-103, MWGS-29A, MWGS-30A, EW-06, and EW-07) (pl. 1). The presence of jet fuel implied that the cones of depression around the extraction wells had allowed part of the jet fuel to escape its stratigraphic trap. Hydrophobic skimmer pumps were installed in the extraction wells to remove the accumulating jet fuel. The amount of product removed to date by the skimmer pumps in those wells is not known with certainty. Recovery efforts are ongoing.

Hydraulic effects from the extraction wells near tank 1 also can be seen west of the tank. Prior to operation of extraction-well EW-02 (pl. 1 ), the concentrations of BTEX ranged from less than $10 \mu \mathrm{g} / \mathrm{L}$ to about $150 \mu \mathrm{g} / \mathrm{L}$ at well EW-02 and were greater than $100 \mu \mathrm{g} / \mathrm{L}$ at well MW-07, approximately $60 \mathrm{ft}$ northeast of well EW-02. Within a few months following the start-up of extraction-well EW-02, the concentrations of BTEX in ground water at well MW-07 declined to values generally less than $50 \mu \mathrm{g} / \mathrm{L}$ (fig. 17A), and by the end of this investigation (September 1995), the BTEX concentrations at MW-07 were below detection limits $(2 \mu \mathrm{g} / \mathrm{L}$ for benzene, toluene, and ethylbenzene, and $4 \mu \mathrm{g} / \mathrm{L}$ for total xylenes). These data imply that extraction well EW-02 was capturing the contaminated ground water that otherwise may have been transported along flowpaths in the vicinity of well MW-07. Supporting evidence that EW-02 was capturing contaminated ground water from the surrounding area can be seen in the increased contaminant concentrations at well EW-02 following its start-up (fig. 17B).

The ground-water contamination in the northeastern part of the facility also was hydraulically affected by operation of extraction wells. Evidence for capture of ground-water contamination by the extraction wells can be seen in the 

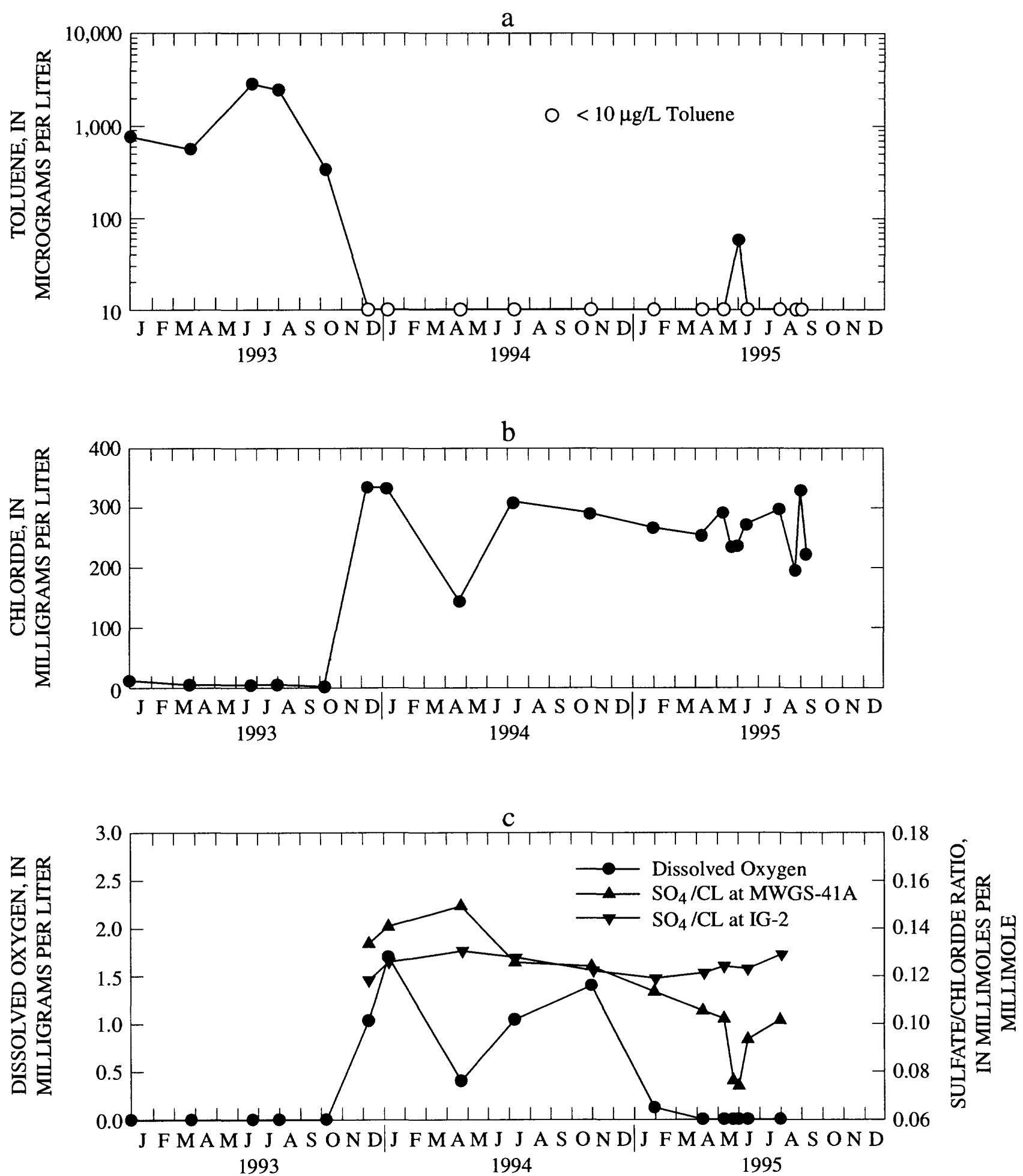

Figure 16. Toluene (a), chloride (b), and dissolved oxygen concentrations, sulfate/chloride ratios at well MWGS-41A, and sulfate/chloride ratios at infiltration-gallery 2 (c), Defense Fuel Supply Point, Hanahan, S.C., 1993-95. 

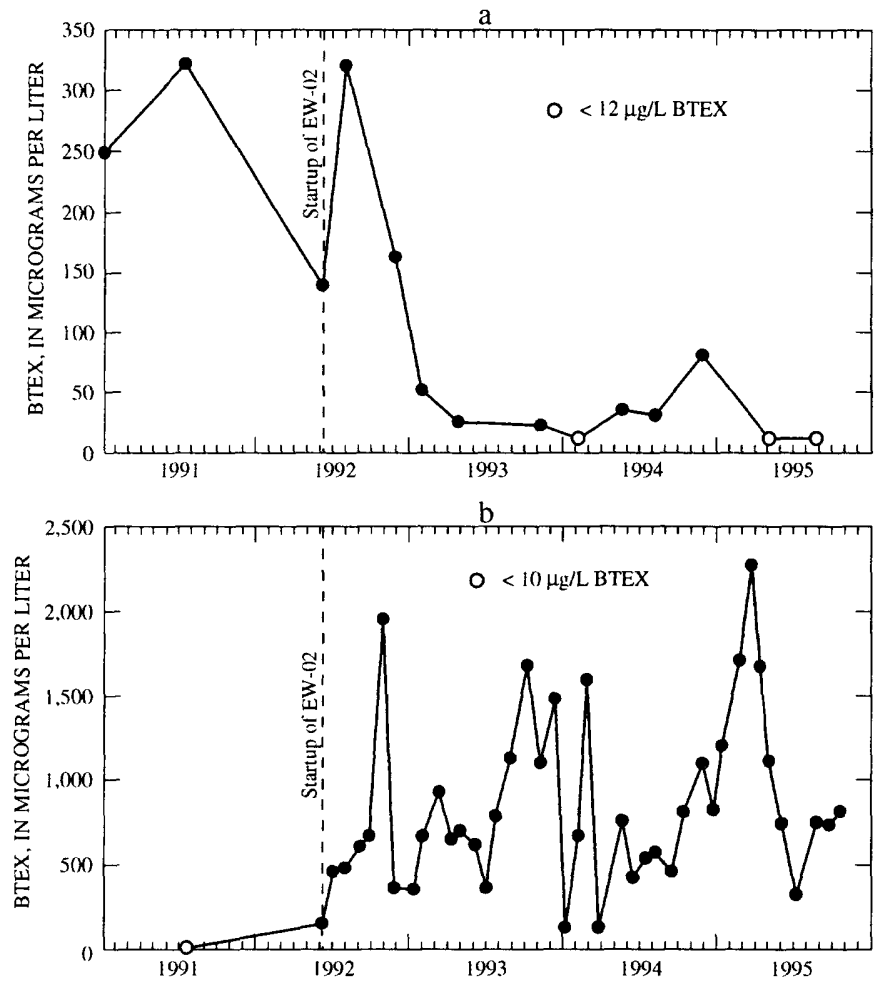

Figure 17. Concentration of combined benzene, toluene, ethylbenzene, and total xylenes in ground water recovered from wells MW-07 (a) and EW-02 (b), Defense Fuel Supply Point, Hanahan, S.C., 1991-95.

contaminant concentration changes at extractionwell EW-11. On the three sample-collection dates prior to full start-up of well EW-11 (January 27, 1992), the toluene concentration ranged from 72 to $95 \mu \mathrm{g} / \mathrm{L}$. In the months following start-up of well EW-11, the toluene concentration in water pumped from the well increased to $600 \mu \mathrm{g} / \mathrm{L}$, indicating that the well was collecting groundwater contamination from the surrounding area. Similar increases were noted in the concentrations of ethylbenzene and total xylenes.

\section{GROUND-WATER REMEDIATION IN GOLD CUP SPRINGS SUBDIVISION}

In general, concentrations of ground-water contaminants decreased in Gold Cup Springs subdivision during the course of this investigation. The ground-water quality north of tanks 2 and 3 was influenced by engineered bioremediation and hydraulic remediation. Because localized shallow clay layers north of tank 1 would have impeded the downward movement of nutrient-amended infiltration-gallery water, the engineered remediation system north of tank 1 relied on hydraulic controls. Nevertheless, the data suggest that bioremediation and hydraulic remediation were contaminant-depletion mechanisms in the subdivision north of the facility. Some effects of the remediation can be seen by examining changes in the distribution of BTEX concentrations in Gold Cup Springs subdivision north of tank 1 . Fifty-four days following start-up of the extraction-well system north of tank 1, the BTEX concentrations in the subdivision were higher than 3,000 $\mu \mathrm{g} / \mathrm{L}$ at wells PW-02 and MWGS-22 and higher than $4,000 \mu \mathrm{g} / \mathrm{L}$ at well $\mathrm{MW}-04$ (fig. 18 and pl. 1). After approximately 3 years of extraction-well operation, however, the BTEX concentrations had declined by about 60 percent at wells PW-02 and MWGS-22 and by more than 80 percent at well MW-04 (fig. 19). Despite the general decrease in contamination north of tank 1 , 


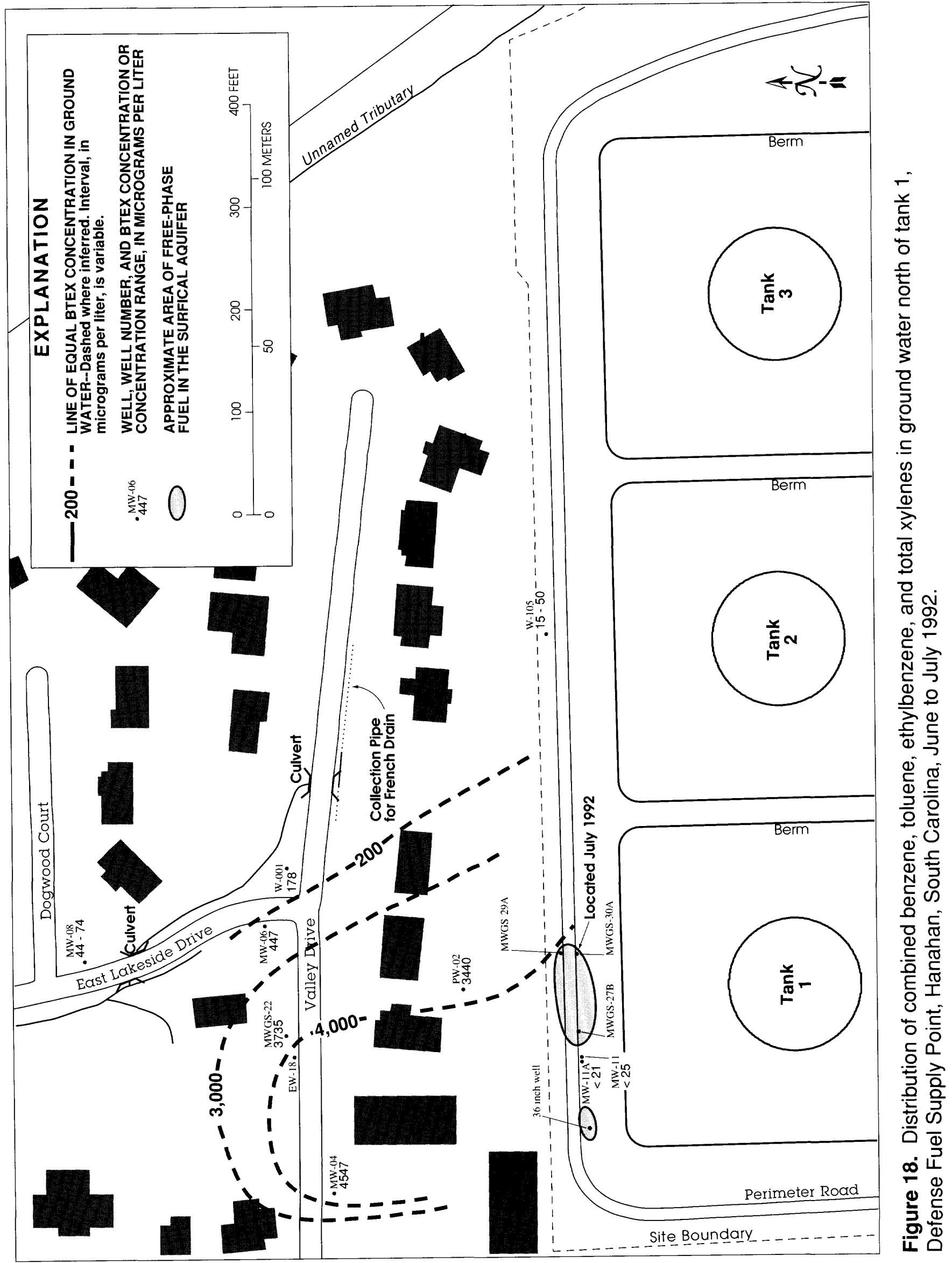

38 Remediation of Petroleum Hydrocarbon-Contaminated Ground Water in the Vicinity of a Jet-Fuel Tank Farm, Hanahan, South Carolina 


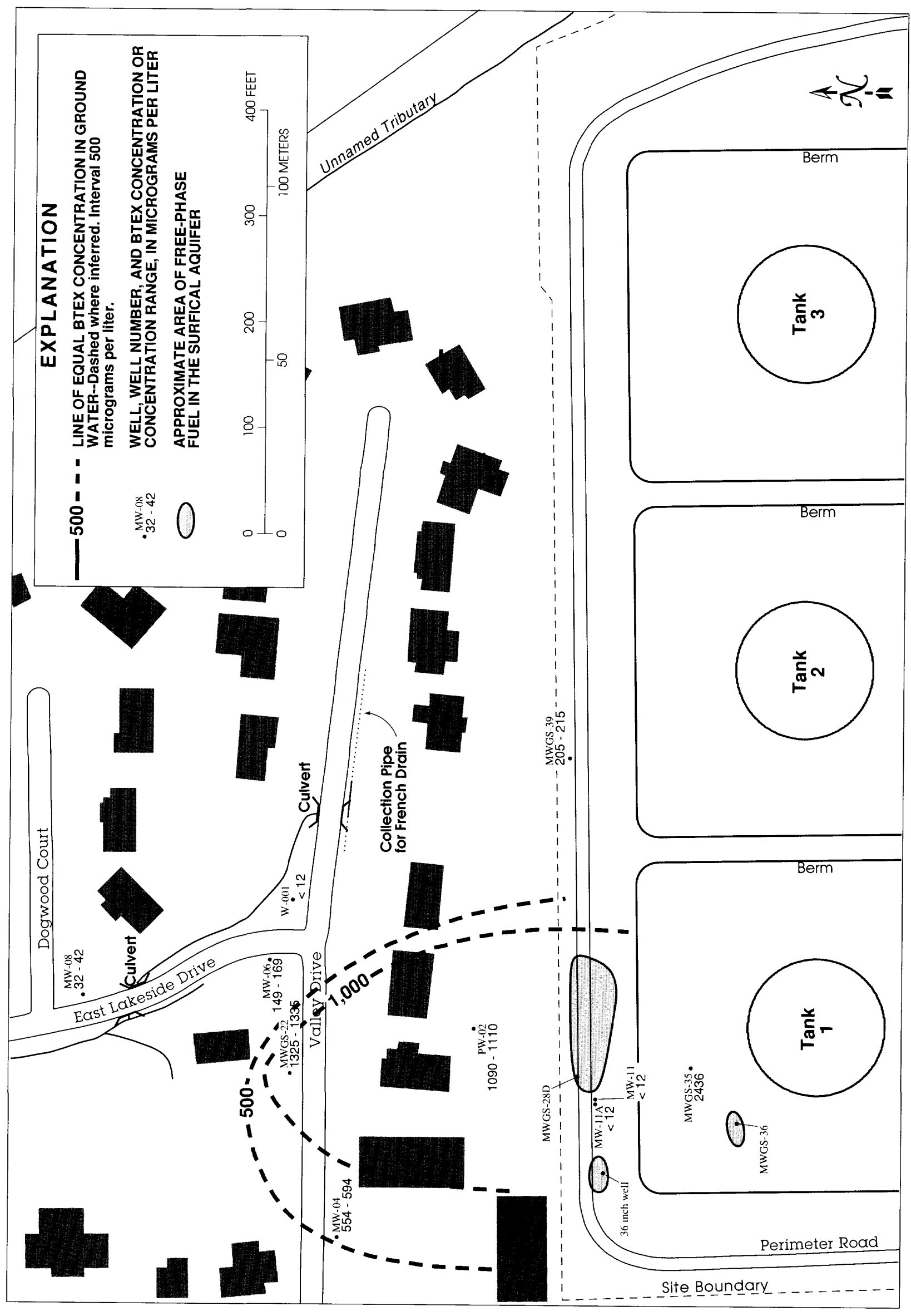

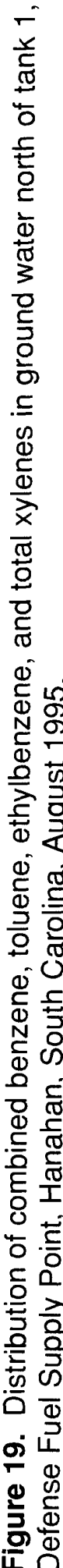


the presence of free-phase fuel in ground-water at the tank- 1 basin allowed continued occasional releases of dissolved petroleum-hydrocarbon contamination to move through the subdivision.

\section{Bioremediation}

Laboratory and field evidence indicated that the petroleum-hydrocarbon contamination in Gold Cup Springs subdivision was being actively bioremediated. Because nutrients were not continuously added to the ground water north of tank 1, microbial ground-water remediation in that area was dominated by natural processes. Although it is difficult to differentiate the waterquality changes resulting from hydraulic remediation relative to bioremediation in ground water beneath the subdivision north of tanks 2 and 3, both were shown to be important contaminantdepletion mechanisms in upgradient areas, and the data imply that both were active influences on ground-water quality near down-gradient areas as well.

\section{Laboratory Evidence}

A laboratory investigation using sediment collected from the vicinity of extraction-well EW-18 (Chapelle and others, 1996) showed that the subsurface microbes were capable of degrading toluene under sulfate-reducing conditions, which was the prevailing TEAP at the collection site. The laboratory-derived depletion rate $\left(\mathrm{k}_{\mathrm{tol}}\right)$ was -0.01 per day $\left(\mathrm{d}^{-1}\right)$. Although toluene biodegraded under sulfate-reducing conditions, it was not significantly biodegraded under nitrate-reducing, $\mathrm{Fe}$ (III)-reducing, or methanogenic conditions. These data implied that the microbial populations had adapted to the presence of contamination and to sulfate reduction as the prevailing TEAP condition.

Biodegradation of benzene using aquifer sediments from Gold Cup Springs subdivision also was examined. Two investigations of the contaminated aquifer sediments found that benzene degraded at low but measurable rates under sulfate-reducing, but not methanogenic conditions (Chapelle and others, 1996; Derek Lovley, University of Massachusetts, written commun., 1995).

The rate of benzene uptake under sulfatereducing conditions north of tank 1 was highly variable. In some studies of sediment from the facility, the rates of anaerobic benzene degradation were so slow that they could not be detected by monitoring benzene loss with time in the aquifer (Chapelle and others, 1996) or in laboratory incubations (Derek Lovley, University of Massachusetts, unpublished data, 1995). In these instances, benzene degradation was detectable only by the more sensitive technique of monitoring production of ${ }^{14} \mathrm{CO}_{2}$ from $\left[{ }^{14} \mathrm{C}\right]$-benzene (Derek Lovley, University of Massachusetts, written commun., 1995).

In one sediment sample collected from the facility, however, located near well MWGS-20, and incubated under strict anaerobic conditions, benzene (about 3 micromoles per liter $[\mu \mathrm{M}]$ ) was consumed rapidly in all four replicate vials without a lag (fig. 20). Benzene continued to be consumed with repeated feedings, represented in figure 20 by the repeated declines in concentration after each injection of new benzene. The initial concentration of benzene in the microcosm was about $3 \mu \mathrm{M}$. Benzene increases in figure 20 represent refeeding of benzene to the sediment. Because of slight differences in the rates of benzene uptake in replicate incubations, the data from one sediment incubation is shown. However, this same pattern was observed in all four of the replicate incubations (Derek Lovley, University of Massachusetts, written commun., 1995).

When the TEAP in the microcosms was evaluated with $\left[2-{ }^{14} \mathrm{C}\right]$-acetate (Lovley and others, 1994a), there was production of ${ }^{14} \mathrm{CO}_{2}$, but not radio-labeled methane $\left({ }^{14} \mathrm{CH}_{4}\right)$, indicating that methanogenesis was not actively metabolizing the substrate. The addition of $1 \mathrm{mM}$ molybdate inhibited sulfate reduction, and a corresponding decrease in ${ }^{14} \mathrm{CO}_{2}$ production was observed. 


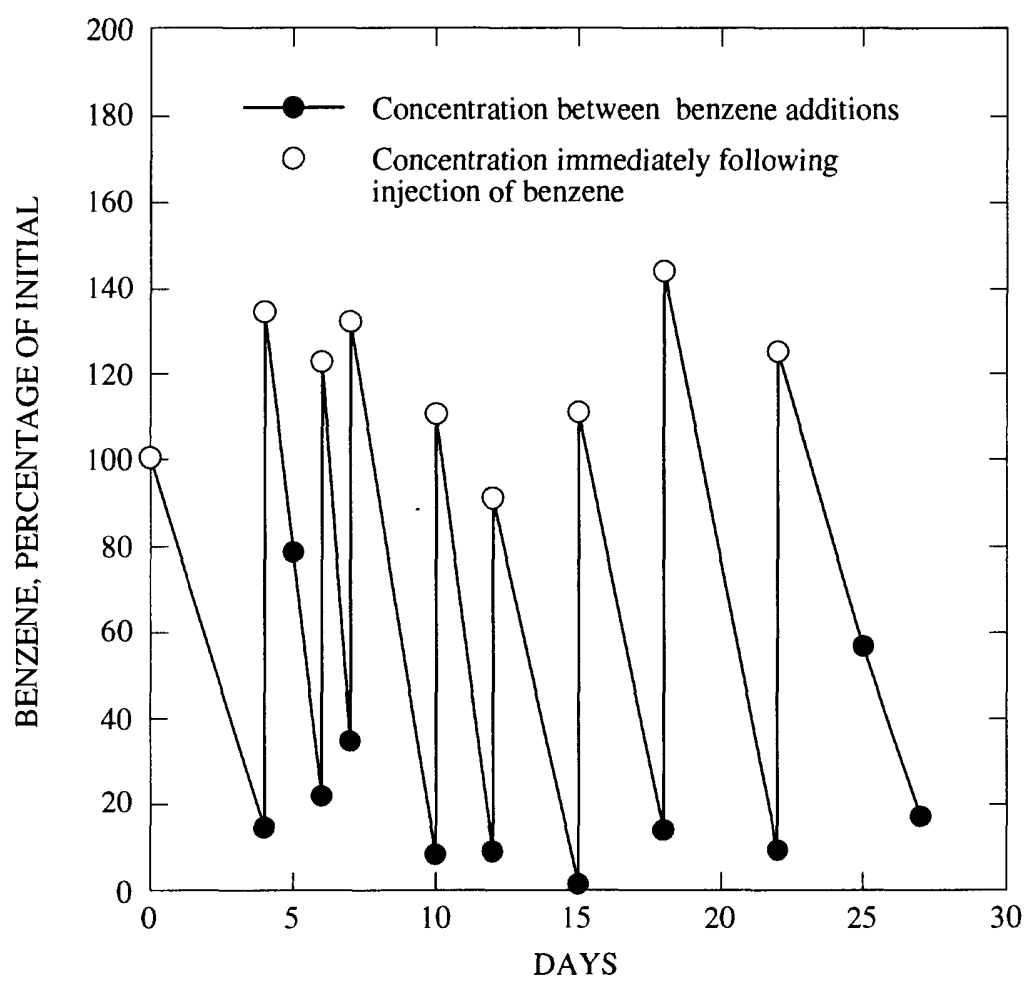

Figure 20. Benzene consumption in sediments under sulfate-reducing conditions following initial feeding and subsequent re-feedings, Defense Fuel Supply Point, Hanahan, S.C.

Thus, sulfate reduction was the predominant TEAP in the microcosms. This was surprising because $\mathrm{Fe}(\mathrm{III})$ reduction was the typical TEAP at the location where the sample was collected. Microbial activity in the microcosms apparently had depleted the available Fe(III) and shifted to sulfate reduction.

The TEAP shift is of interest for a variety of reasons. Rapid anaerobic benzene degradation coupled to $\mathrm{Fe}$ (III) reduction previously has not been observed in these sediments unless an $\mathrm{Fe}(\mathrm{III})$-chelator was added to make Fe(III) more available for reduction (Lovley and others, 1994b). One laboratory study (using sediment from a site in California), however, has shown that sulfate-reducing bacteria sometimes are capable of rapidly degrading benzene anaerobically (Lovley and others, 1995). The typical persistence of benzene under sulfate-reducing conditions at many field sites implies that rapid degradation of benzene under sulfate-reduction requires unique conditions not yet identified. As will be shown in a later section, the shift from iron reduction to sulfate reduction that preceded rapid benzene removal from the laboratory microcosms, was mimicked under field conditions at well MW-04. The subsequent rapid anaerobic depletion of benzene at well MW-04 suggested that the depletion mechanism was microbially related.

\section{Field Evidence}

Field evidence supporting biodegradation of the petroleum hydrocarbon contamination in ground water north of the facility could be seen in the depletion of toluene along the flowpath. The rate of toluene depletion $\left(\mathrm{k}_{\mathrm{to}}\right)$ along a flowpath northward from tank 1 into Gold Cup Springs subdivision was -0.0075 to $-0.03 \mathrm{~d}^{-1}$ under predominantly sulfate-reducing conditions. The depletion rate corresponded approximately with the lab-derived $k_{\text {tol }}$ rates $\left(-0.1 \mathrm{~d}^{-1}\right)$ for sulfate reduction (Chapelle and others, 1996). The agreement between laboratory- and field-derived 
rate constants implied that toluene disappearance along the flowpath was the product of microbial degradation under predominantly sulfate-reducing conditions (Chapelle and others, 1996).

Additional evidence that concentrations of ground-water contaminants have decreased in Gold Cup Springs subdivision can be seen in the surface-water-quality data collected from SW-12, a sampling point for a french-drain system that collects shallow ground water from the southeast side of Valley Drive, north of tank 3 (pl. 1). The 1992 ethylbenzene and toluene concentrations were greater than $15 \mu \mathrm{g} / \mathrm{L}$ (fig. 21A), benzene concentrations were greater than $25 \mu \mathrm{g} / \mathrm{L}$ (fig. 21B), and total xylene concentrations were greater than $50 \mu \mathrm{g} / \mathrm{L}$ (fig. 21B). Concentrations declines were observed in the next two samplings (January and July 1993). For the next several samplings, the total BTEX concentration varied between about 25 to $60 \mu \mathrm{g} / \mathrm{L}$. As of the final sampling (August 1995) during this investigation, benzene, toluene, and ethylbenzene were not detected (less than $2 \mu \mathrm{g} / \mathrm{L}$ ) and the total xylenes concentration had decreased to $8.5 \mu \mathrm{g} / \mathrm{L}$ (fig. $21 \mathrm{~A}$ and 21B). Because SW-12 collected drainage water from a broad area, it is difficult to relate specific causes to the concentration decreases; however, in the months prior to the decline, extraction wells upgradient from the French-drain system were operated intermittently, and nutrientenriched infiltration-gallery water had been released intermittently to the aquifer. Once infiltration-gallery water was allowed to recharge the aquifer continuously (April 1993), the concentration of toluene at SW-12 decreased from $22 \mu \mathrm{g} / \mathrm{L}$ (November 2, 1992) to undetectable $(<0.2 \mu \mathrm{g} / \mathrm{L})$ concentrations (July 1, 1993).

A high concentration of chloride $(240 \mathrm{mg} / \mathrm{L})$ was detected in French-drain water at SW-12 and $260 \mathrm{mg} / \mathrm{L}$ at SW-01 in August 1995, indicating that the drains were collecting water introduced to the aquifer from infiltration-gallery 2. Moreover, the $\mathrm{SO}_{4} / \mathrm{Cl}$ ratios in SW-01 and SW-12 $(0.105$ and $0.111 \mathrm{mM} / \mathrm{mM}$, respectively) were lower than in the infiltration-gallery water $(0.129 \mathrm{mM} / \mathrm{mM})$, implying a loss of sulfate to a greater extent than can be accounted for by dispersion. The probable sulfate-removal mechanism was sulfate reduction coupled to oxidation of organic contamination. Thus, the data imply that the decreases in ground-water contaminant concentration at SW-12 were the result of engineered hydraulic remediation and engineered bioremediation.

Additional evidence suggested the possibility that benzene was being microbially degraded under anaerobic conditions in ground water beneath Gold Cup Springs subdivision. A laboratory experiment, discussed in an earlier section, showed subsurface microbes from the facility were capable of rapidly degrading benzene under sulfate-reducing conditions in sediments that had previously been iron reducing. This finding was of particular interest because rapid depletion of benzene was observed in ground water at MW-04 following that same sequence of TEAP shift. Evidence for potential microbially mediated benzene loss can be seen in the temporal concentration changes of benzene, hydrogen, sulfate, and iron(II) at well MW-04 (fig. 22).

The dominant constituents of the BTEX fraction in the ground water at well MW-04 were benzene and total xylenes. Until April 1993, benzene concentrations ranged from 860 to $1,700 \mu \mathrm{g} / \mathrm{L}$ in the ground water at well MW-04 (fig. 22A).

The concentrations of benzene sharply decreased between April 1993 and July 1994. The changes in hydrogen concentration in the aquifer at well MW-04 suggested that the benzene depletion was related to the predominant TEAP. When ground water at the well was sampled in June 1991 prior to the decrease in benzene concentrations, the hydrogen concentration $(5.4 \mathrm{nM})$ indicated that the predominant TEAP was methanogenesis (fig. 22B). The lack of measurable sulfate in the ground water provided supporting evidence that methanogenesis was the predominant TEAP (fig. 22C).

By July 8,1992 , the sulfate concentration had increased to $0.41 \mathrm{mg} / \mathrm{L}$, and the hydrogen concentration had declined to $3 \mathrm{nM}$, suggesting 

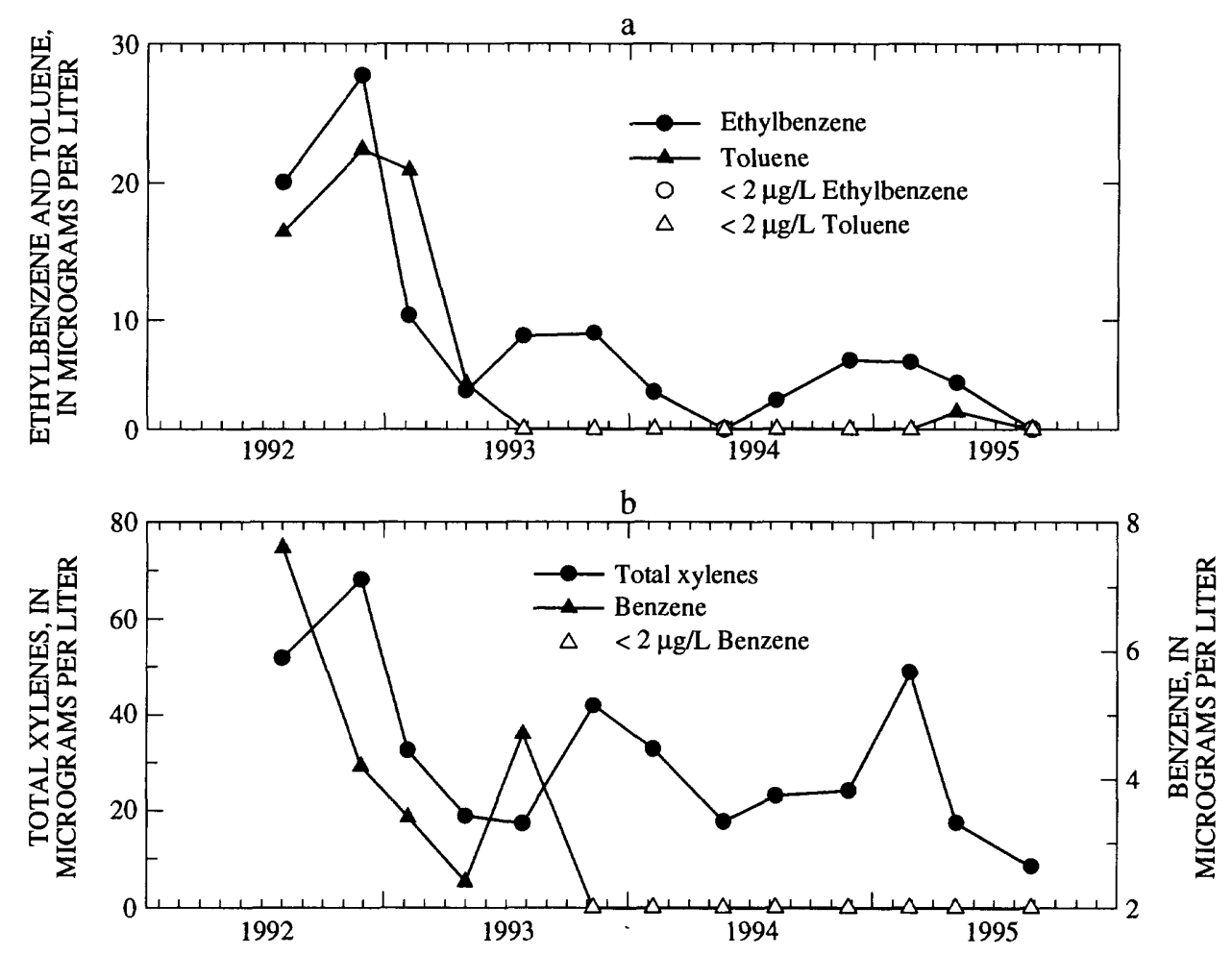

Figure 21. Changes in concentrations of ethylbenzene and toluene (a), and total xylenes and benzene (b) at SW-12, the sampling point for the French drain collecting ground water from the southeastern side of Valley Drive, Gold Cup Springs subdivision, Hanahan, S.C., 1992-95.

that sulfate reduction was sequestering the electron flow. Between the time that the aquifer at MW-04 was methanogenic (June 1991) and the time that the aquifer was sulfate reducing (July 1992), the concentration of benzene declined only slightly, from 1,100 to $990 \mu \mathrm{g} / \mathrm{L}$ (fig. 22A). Over that same time interval, however, the toluene concentration increased from 37 to $150 \mu \mathrm{g} / \mathrm{L}$ (Petkewich and others, in press). Thus, it appears that advective transport was delivering a pulse of additional BTEX contamination from upgradient areas during that time interval. If enhanced biodegradation of benzene and toluene was taking place during this time interval, the depletion may have been masked by advective delivery of contamination containing increased concentrations of some of the compounds.

When the available sulfate was depleted, the hydrogen concentration rose to $6.1 \mathrm{nM}$, indicating that methanogenesis had once again become the predominant TEAP. With the onset of methano- genesis, the benzene concentration increased to $1,500 \mu \mathrm{g} / \mathrm{L}$ (fig. 22A), suggesting that the delivery of benzene to the aquifer at well MW-04 exceeded the removal rate.

Between November 1992 and January 1993, rainfall infiltration apparently introduced minor concentrations of DO to the aquifer. The DO concentration apparently was low enough to be completely scavenged by $\mathrm{Fe}$ (II) because DO was not detected in the aquifer at well MW-04. Several lines of evidence support this conclusion. The first is the decline in $\mathrm{Fe}$ (II) concentrations at the well from 20 to $17 \mathrm{mg} / \mathrm{L}$ during that time (fig. 22D). The decline probably indicates that $\mathrm{Fe}(\mathrm{II})$ was being removed from solution by oxidation to Fe(III) and precipitation as grain coatings. The second line of evidence is that the hydrogen concentration in the ground water sharply declined from 6.1 to $0.8 \mathrm{nM}$, implying that the predominant TEAP switched to $\mathrm{Fe}(\mathrm{III})$ reduction (fig. 22B). Evidence from other areas at this facility 

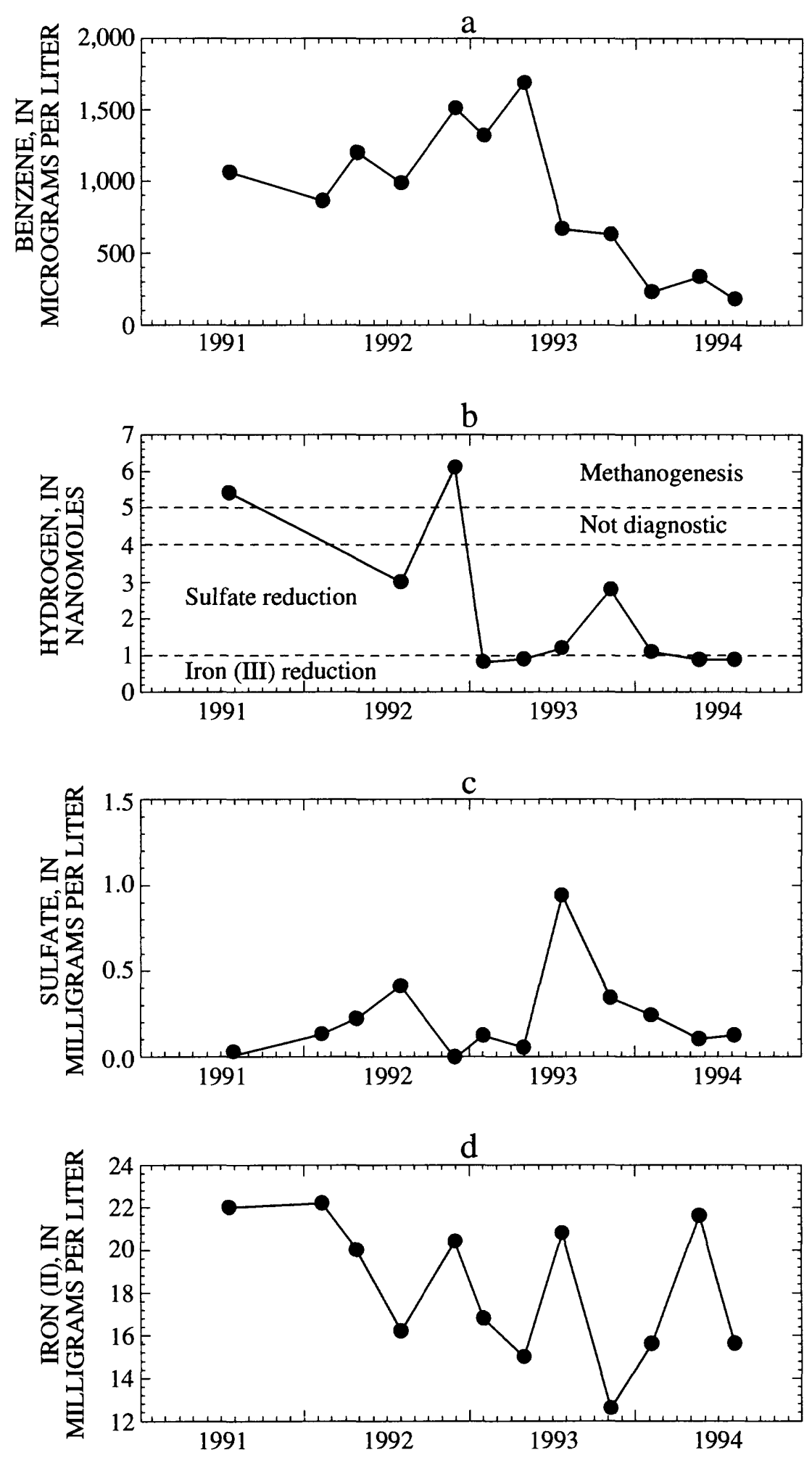

Figure 22. Changes in concentrations of benzene (a), hydrogen (b), sulfate (c), and ferrous iron (d) in ground water at well MW-04, Defense Fuel Supply Point, Hanahan, S.C., 1991-94. 
has demonstrated that oxidation of $\mathrm{Fe}$ (II) to $\mathrm{Fe}(\mathrm{III})$ can cause the predominant TEAP to shift to iron reduction (Vroblesky and Chapelle, 1994).

Despite the apparent shift from methanogenic conditions to $\mathrm{Fe}$ (III)-reducing conditions and the potential for dilution of the contamination by rainwater infiltration between November 1992 and January 1993, the benzene concentration in ground water at well MW-04 declined only slightly (fig. 22A). The concentration was $1,500 \mu \mathrm{g} / \mathrm{L}$ under methanogenic conditions in November 1992 and $1,300 \mu \mathrm{g} / \mathrm{L}$ at the onset of Fe(III)-reducing conditions in January 1993. Thus, dilution of the benzene contamination by rainwater infiltration during this time was considered to be minimal. The persistence of high benzene concentrations three months later implies that benzene was not being degraded under $\mathrm{Fe}$ (III)-reducing conditions. The apparent lack of benzene degradation under Fe(III)-reducing conditions is consistent with laboratory findings that benzene degradation was not observed under $\mathrm{Fe}(\mathrm{III})$-reducing conditions in the absence of an iron chelator (Lovley and others, 1994b).

A marked change in microbial metabolism took place in June 1993, however. As the available Fe(III) apparently was depleted, the hydrogen concentration in ground water at well MW-04 increased to $1.2 \mathrm{nM}$, implying that sulfate reduction had become the predominant TEAP (fig. 22B). Sulfate reduction remained the predominant TEAP until January 1994. During the time that sulfate reduction was the predominant TEAP, benzene concentrations substantially declined (fig. 22A).

The data suggest that when sulfate reduction was the predominant TEAP in 1993, benzene removal mechanisms outpaced the rate at which benzene was being delivered to the site by advective ground-water transport. The observed decline in benzene concentrations under sulfatereducing conditions is consistent with laboratory results (Lovley and others, 1995) that showed the capability of sulfate-reducing bacteria to anaerobically mineralize benzene. In the field and laboratory observations, the capacity for rapid anaerobic benzene uptake was associated with a shift from $\mathrm{Fe}$ (III) reduction to sulfate reduction. It is yet to be determined whether this TEAP shift promotes benzene degradation and, if so, what factors associated with the shift promote benzene degradation.

\section{Hydraulic Remediation}

In addition to the line of extraction wells on the facility that intercepted contaminated ground water prior to being transported offsite, extraction-well EW-18 (pl. 1), in Gold Cup Springs subdivision, provided a mechanism for hydraulic capture of contaminated ground water further downgradient. Some effects of well EW-18 can be seen in the changing ground-water quality observed at well MWGS-22, east of well EW-18. Following start-up of extraction-well EW-18, the BTEX concentrations in MWGS-22 declined (fig. 23). The decline was sharpest for benzene and ethylbenzene (fig. 23A), decreasing from concentrations between 230 to $430 \mu \mathrm{g} / \mathrm{L}$ to concentrations ranging from 40 to $260 \mu \mathrm{g} / \mathrm{L}$, respectively. Toluene and total xylene concentrations also showed general decreases, although part of the toluene decrease took place prior to operation of well EW-18 (fig. 23B).

The benzene and ethylbenzene concentrations decreased rapidly soon after start-up. Occasional short-term increases in concentrations indicated that pulses of contamination continued to be released from upgradient contamination sources; however, the overall trend in contaminant concentration was downward. Thus, the data indicate that operation of extraction-well EW-18 decreased the ground-water-contaminant concentration in the vicinity of well MWGS-22.

In contrast to the apparent effectiveness of EW-18 for removal of contaminated ground water in its immediate vicinity, the operation of EW-18 appears to have had little noticeable effect on the contaminant concentrations discharging to surface water downgradient from EW-18 at surfacewater-collection-site SW-09 (pl. 1). Although only one time point for SW-09 was available 

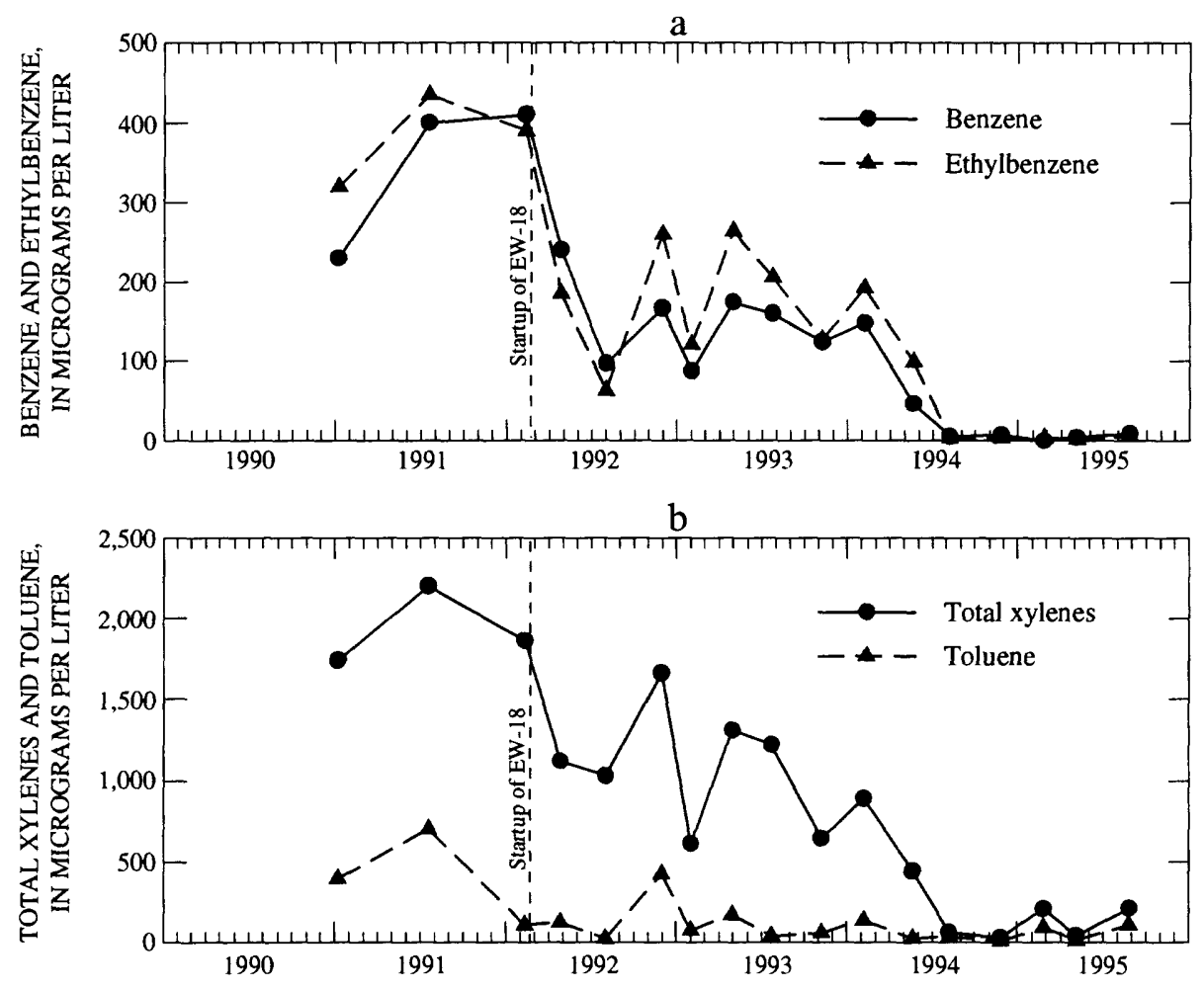

Figure 23. Benzene and ethylbenzene (a), and total xylenes and toluene (b) in ground water at well MWGS-22, Defense Fuel Supply Point, Hanahan, S.C., 1990-95.

prior to EW-18 start-up, no rapid change in concentration at SW-09 was noted following start-up of EW-18 (Petkewich and others, in press). Pulses of contamination continued to discharge at the sampling point as late as 1994. The probable explanation is that the sampling point at SW-09 is the discharge pipe for a drain that collects water from near Valley Drive and is connected to a drainage system south of Valley Drive (upgradient from well EW-18). Because a large fraction of the discharging water at SW-09 was derived from upgradient of EW-18, it is not surprising that the operation of EW-18 had little effect on concentrations in the discharging water.

A decrease in contaminant concentrations discharging from ground water to surface water was observed, however, at surface-water site SW-01 (pl. 1) downgradient from the extraction wells north of tank 2. The dominant BTEX constituent at SW-01 was total xylenes. In the months following start-up of the tank- 2 extraction wells, the concentration of total xylenes at SW-01 decreased from $36 \mu \mathrm{g} / \mathrm{L}$ (prior to start-up in January 1992) to $25 \mu \mathrm{g} / \mathrm{L}$ in April 1992 and $13 \mu \mathrm{g} / \mathrm{L}$ in July 1992 (Petkewich and others, in press).

\section{CONCLUSIONS}

The surficial aquifer beneath the Defense Fuel Supply Point in Hanahan, S.C., contained ground water contaminated with petroleum hydrocarbons. The principle contaminants were BTEX compounds. The USGS, in cooperation with the U.S. Department of Defense, investigated the potential for in situ bioremediation of the ground-water contamination.

During the course of the investigation, several factors were identified to affect contaminant movement and remediation at the facility. At well MWGS-32A, rainwater infiltration temporarily diluted the ground-water contamination, while recharging water in a contaminant-source area 
upgradient from well MWGS-32A leached contaminants out of the soil zone and increased contaminant concentrations in the ground water. Seasonal differences in ground-water levels locally changed ground-water flow directions and changed the locations of gaining and losing reaches of the stream immediately east of the facility. The presence of a gaining reach adjacent to areas of ground-water contamination in the facility and a losing reach further downstream implies the possibility that ground-water contamination from the facility could discharge to the stream, be transported downstream, and enter the aquifer at a new point in the losing reach.

Exploratory drilling north of tank 1 showed that a petroleum spill in an area containing discontinuous clay layers can result in free-phase fuel becoming stratigraphically trapped beneath the water table. Because the petroleum was isolated beneath clay layers, advective transport of nutrients to the contaminated horizon was limited. Thus, the JP-4 at tank 1 was relatively unweathered compared to the free-phase fuel present in the tank 3 basin. Moreover, the presence of an overlying clay layer made delivery of nutrients to the contaminated horizon impractical north of tank 1 using the infiltration-gallery approach in operation at the facility.

The chemical factors influencing biodegradation of the contamination were related to the type and amount of electron acceptors available for microbial activity. Because the most efficient electron acceptors typically were depleted in the contaminated horizons, relatively inefficient electron-accepting processes, such as sulfate reduction and methanogenesis, tended to dominate at the most contaminated zones. However, introduction of more efficient electron acceptors, such as oxygen or nitrate, by rainwater infiltration or artificial recharge could allow the predominant electron accepting activity to shift to oxygen or nitrate reduction, increasing the biodegradation efficiency.

The investigation involved design, operation, and monitoring of an engineered groundwater-remediation system that utilized bioremedi- ation and hydraulic-remediation approaches. The bioremediation system involved delivering nitrate- and oxygen-amended water to the contaminated aquifer through infiltration galleries. The hydraulic controls involved contaminatedwater removal by extraction wells in addition to the hydraulic effects associated with injecting water from the infiltration galleries.

Substantial decreases in ground-water-contaminant concentrations were observed during the operation of the remediation system. In the shallow surficial aquifer north of tank 3 at wells MWGS-32A and MWGS-33A, BTEX concentrations decreased from greater than $1,000 \mu \mathrm{g} / \mathrm{L}$ prior to operation of the system to less than $100 \mu \mathrm{g} / \mathrm{L}$ during operation. Ground-water contamination persisted in parts of the aquifer not affected by the infiltration-gallery water, such as in the deeper part of the surficial aquifer (about 16-30 ft bls) north of tank 3 , and in source areas upgradient from the remediation system that continued to leach occasional hydrocarbon pulses to the aquifer.

Laboratory and field evidence support the conclusion that bioremediation was an important removal mechanism for the ground-water contamination. The laboratory studies measured microbial degradation potential and rates using sediment collected from the study area. The field evidence included monitoring microbially active constituents in ground-water. Sharp decreases in toluene, ethylbenzene, and total xylene concentrations at extraction-well EW-11 accompanied the arrival of nitrate injected upgradient from the well. The chloride and DIC concentrations and $\mathrm{NO}_{3} / \mathrm{Cl}$ ratios at extraction-well EW-11 suggested that the engineered addition of nitrate to the ground water allowed the native microbial community to initiate nitrate reduction, which contributed to contaminant-concentration decreases.

Ground-water remediation at several wells on the facility appeared to be the result of both engineered bioremediation and hydraulic remediation. These wells include MW-12, MW-12A, MWGS-32A, MWGS-33A, and MWGS-41A. Hydraulic control was the principle engineered 
remediation aspect used north of tank 1 because localized shallow clay layers restricted downward movement of nutrient-amended infiltration-gallery water to target areas. The hydraulic remediation in that area allowed mobilization and capture of stratigraphically trapped free-phase fuel.

Hydraulic effects of the remediation can be seen in other areas in the facility as well. Within a few months following the start-up of extractionwell EW-02, the concentrations of BTEX in ground water at nearby well MW-07 declined from greater than $100 \mu \mathrm{g} / \mathrm{L}$ to less than $50 \mu \mathrm{g} / \mathrm{L}$, and by the end of this investigation (September 1995), the BTEX concentrations at well MW-07 were below detection limits $(2 \mu \mathrm{g} / \mathrm{L}$ for benzene, toluene, and ethylbenzene, and $4 \mu \mathrm{g} / \mathrm{L}$ for total xylenes). Increasing BTEX concentrations at extraction wells, such as EW-02, following startup indicated that the wells were capturing contamination.

In general, concentrations of ground-water contaminants also decreased in Gold Cup Springs subdivision during this investigation. After approximately 3 years of using engineered hydraulic remediation north of tank 1, the BTEX concentrations had declined by about 60 percent at wells PW-02 and MWGS-22 and by more than 80 percent at well MW-04. Although occasional pulses of dissolved contamination from the tank 1 source area continued to migrate through the subdivision, the operation of extraction-well EW-18 in Gold Cup Springs subdivision resulted in a general decrease in BTEX concentrations at nearby well MWGS-22.

Although it is difficult to differentiate the water-quality changes resulting from hydraulic remediation relative to bioremediation in ground water beneath the subdivision north the facility, both were shown to be important contaminantdepletion mechanisms in upgradient areas, and the data imply that both were active influences on ground-water quality near down-gradient areas as well. The laboratory evidence included observed biodegradation in microcosms using sediment from the subdivision. Field evidence included loss of sulfate along flowpaths (as evidenced by changes in the $\mathrm{SO}_{4} / \mathrm{Cl}$ ratio) and biodegradation rates calculated from toluene disappearance along flowpaths. Decreases in contaminant concentrations north of tanks 2 and 3 were observed at ground-water-discharge points (SW-01 and SW-12) following operation of the remediation system.

Free-phase jet fuel in ground water upgradient from the remediation system (north of tanks 1 and 3) continued to release dissolved petroleum hydrocarbons. At times, the releases apparently were sufficient to allow contaminant migration past the engineered remediation system and into the subdivision. The data from this investigation indicate that an approach combining engineered and natural bioremediation and hydraulic remediation can be effective in removing petroleum hydrocarbon contamination from ground water, but attaining maximum effectiveness of the system requires removal of the free-phase fuel.

\section{SELECTED REFERENCES}

Aelion, C.M., and Bradley, P.M., 1991, Aerobic biodegradation potential of subsurface microorganisms from a jet fuel-contaminated aquifer: Applied and Environmental Microbiology, v. 57, p. 57-63.

Beller, H.R., Reinhard, Martin, and Grbic-Galic, Dunja, 1992, Metabolic by-products of anaerobic toluene degradation by sulfate-reducing enrichment cultures: Applied Environmental Microbiology, v. 58, p. 3192-3195.

Berry-Spark, K.L., Barker, J.F., Major, D., and Mayfield, C.I., 1986, Remediation of gasoline-contaminated ground waters - a controlled experiment: in Proceedings, Petroleum Hydrocarbons and Organic Chemicals in Ground Water - Prevention, Detection, and Restoration, National Water Well Association/American Petroleum Institute, Dublin, Ohio, p. 613-623. 
Bouwer, Herman, and Rice, R.C., 1976, A slug test for determining hydraulic conductivity of unconfined aquifers with completely or partially penetrating wells: Water Resources Research, v. 12, p. 432-428.

Bradley, P.M., Aelion, C.M., and Vroblesky, D.A., 1992, Influence of environmental factors on denitrification in sediment contaminated with JP-4 fuel: Ground Water, v. 30, no. 6, p. 843-848.

Bradley, P.M., Chapelle, F.H., and Vroblesky, D.A., 1993a, Effects of $\mathrm{Pb}$ and terminal-electron-accepting processes on organic acid concentrations in contaminated aquifer sediments: Proceedings of the 7th Toxic Substances Hydrology (Toxics) Technical Meeting, sponsored by U.S. Geological Survey, September 20-24, 1993, Colorado Springs, $\mathrm{CO}$.

Bradley, P.M., Chapelle, F.H., and Vroblesky, D.A., 1993b, Does lead affect microbial metabolism in aquifer sediments under different terminal electron accepting conditions?: Geomicrobiology Journal, v. 11, p. 85-94.

Chapelle, F.H., Bradley, P.M., Lovley, D.R., and Vroblesky, D.A., 1996, Measuring rates of biodegradation in a contaminated aquifer using field and laboratory methods: Ground Water, v. 34, no. 4, p. 691-698.

Chapelle, F.H., and Lovley, D.R., 1990, Hydrogen concentrations in ground water as an indicator of bacterial processes in deep aquifer systems: in Proceedings of the First International Symposium on the Microbiology of the Deep Subsurface, U.S. Environmental Protection Agency, Orlando, Florida.

1992, Competitive exclusion of sulfate reduction by $\mathrm{Fe}(\mathrm{III})$-reducing bacteria: A mechanism for producing discrete zones of high-iron ground water: Ground Water, v, 30, p. 29-36.
Chapelle, F.H., and McMahon, P.B., 1991, Geochemistry of dissolved inorganic carbon in a coastal plain aquifer: Sulfate from confining beds as an oxidant in microbial $\mathrm{CO}_{2}$ production, Journal of Hydrology, v. 127, p. 85-108.

Chapelle, F.H., McMahon, P.B., Dubrovsky, N.M., Fujii, R.F., Oaksford, E.T., and Vroblesky, D.A., 1995, Deducing the distribution of terminal electron-accepting processes in hydrologically diverse ground water systems: Water Resources Research, v. 31, no 2. , p. 359-371.

Conrad, R., Lupton, F.S., and Zeikus, J.G., 1987, Hydrogen metabolism in a mildly acidic lake sediment (Lake Mendota): FEMS Microbiology and Ecology, v. 45, p. 107-115.

Dames \& Moore, Inc., 1982, Environmental hydrogeological study, project CHS 80-16, Defense Fuel Support Point, Charleston, South Carolina: Consultant's report to Defense Fuel Supply Center, August 24, 1982, $49 \mathrm{p}$.

Daubel, K.J., 1984, Water quality biological study no. 32-24-0592-85, Gold Cup Lake Development surface-water contamination, Defense Fuel Support Point, Charleston, South Carolina: Letter report to the Director of the Defense Logistics Agency, July 16-17, 1984, $8 \mathrm{p}$.

Edwards, E.A., and Grbic-Galic, Dunjab, 1992, Complete mineralization of benzene by aquifer microorganisms under strictly anaerobic conditions: Applied and Environmental Microbiology, v. 60, p. 313-322.

Evans, P.J., Mang, D.T., and Young, L.Y., 1991, Degradation of toluene and $m$-xylene and transformation of $o$-xylene by denitrifying enrichment cultures: Applied and Environmental Microbiology, v. 57, p. 450-454.

Gersberg, R.M., Dawsey, W.J., Bradley, M.D., 1991, Biodegradation of monoaromatic hydrocarbons in ground water under denitrifying conditions: Bulletin of Environmental Contaminant Toxicology, v. 47, p. 230-237. 
Gersberg, R.M., Korth, K.G., Rice, L.E., Randall, J.D., Bogardt, A.H., Dawsey, W.J., and Hemmingsen, B.B., 1995, Chemical and microbial evaluation of in situ bioremediation of hydrocarbons in anoxic ground water enriched with nutrients and nitrate: World Journal of Microbiology \& Biotechnology, v. 11, p. 549-558.

Gohn, G.S., Higgins, B.B., Smithe, C.C., and Owens, J.P., 1977, Lithostratigraphy of the deep corehole (Clubhouse Crossroads Corehole 1) near Charleston, S.C., in Rankin, D.W. ed., Studies related to the 1886 Charleston SC earthquake - A preliminary Report, U.S. Geological Survey Professional Paper 1028-E, p. 59-70.

Haag, Franziska, Reinhard, Martin, and McCarty, P.L., 1991, Degradation of toluene and $p$-xylene in anaerobic microcosms - evidence for sulfate as a terminal electron acceptor: Environmental Toxicology and Chemistry, v. 10 , p. 1379-1389.

Hach Company, 1983, Water Analysis Handbook: Loveland, Colorado, Hach Company, 689 p.

Holmer, Marianne, and Kristensen, Erik, 1994, Coexistence of sulfate reduction and methane production in an organic-rich sediment: Marine Ecology, Progress Series 107, v. 1-2, p. 177-184.

Hutchins, S.R., 1991, Biodegradation of monoaromatic hydrocarbons by aquifer microorganisms using oxygen, nitrate, or nitrous oxide as the terminal electron acceptor: Applied and Environmental Microbiology, v. 57, p. 2403-2407.

Hutchins, S.R., and Wilson, J.T., 1991, Laboratory and field studies on BTEX biodegradation in a fuel-contaminated aquifer under denitrifying conditions, in, in situ Bioreclamation, eds. Hinchee, R.E., and Olfenbuttel, R.F., Butterworth-Heinemann, Boston, MA, p. 157-172.

Kimberlin, D.K., and Trimmell, M.L., 1988, Utilization of optoelectronic sensing to determine hydrocarbon thicknesses within confined aquifers, in Proceedings of the Conference on Petroleum Hydrocarbons and
Organic Chemicals in Ground Water - Prevention, Detection and Restoration, National Water Well Association and American Petroleum Institute, November 9-11, 1988, Houston, Texas, p. 255-274.

Lovley, D.R., and Goodwin, Steve, 1988, Hydrogen concentrations as an indicator of the predominant terminal electron-accepting reactions in aquatic sediments: Geochimica et Cosmochimica Acta, v. 52, p. 2993-3003.

Lovley, D.R., Chapelle, F.H., and Woodward, J.C., 1994a, Use of dissolved $\mathrm{H}_{2}$ concentrations to determine distribution of microbially catalyzed redox reactions in anoxic ground water: Environmental Science \& Technology, v. 28, no. 7, p. 1205-1210.

Lovley, D.R., Woodward, J.C., and Chapelle, F.H., 1994b, Stimulated anoxic biodegradation of aromatic hydrocarbons using Fe(III) ligands: Nature, v. 370, p. 128-131.

Lovley, D.R., Coates, J.D., Woodward, J.C., and Phillips, E.J.P., 1995, Benzene oxidation coupled to sulfate reduction: Applied and Environmental Microbiology, v. 61, no. 3, p. 953-958.

Madsen, E.L., 1991, Determining in situ biodegradation - Facts and challenges: Environmental Science \& Technology, v. 25, p. 1663-1673.

McClelland Engineers, Inc., 1987a, Final report, confirmation study, characterization step, Defense Fuel Support Point, Charleston, South Carolina: Consultant's Report to Southern Division Naval Facilities Engineering Command, March 1987, 39 p.

1987b, Addendum \#1, confirmation study, characterization step, Defense Fuel Support Point, Charleston, South Carolina: Consultant's Report to Southern Division Naval Facilities Engineering Command, May 1987, $24 \mathrm{p}$.

McMahon, P.B., Vroblesky, D.A., Bradley, P.M., and Chapelle, F.H., 1995, Evidence for enhanced mineral dissolution in organic-acid rich shallow ground water: Ground Water, v. 33, no. 2, p. 207-216. 
Meadows, J.K., 1987, Ground-water conditions in the Santee Limestone and Black Mingo Formation near Moncks Corner, Berkeley County, South Carolina: South Carolina Water Resources Commission Report 156, $38 \mathrm{p}$.

Mihelcic, James, and Luthy, R.G., 1988, Degradation of polycyclic aromatic hydrocarbon compounds under various redox conditions in soil-water systems: Applied and Environmental Microbiology, v. 54, p. 1182-1187.

National Oceanic and Atmospheric Administration, 1995, Climatological data annual summary, South Carolina, 1994: v. 97, no. 13, $26 \mathrm{p}$.

Newcome, Roy, Jr., 1989, Ground-water resources of South Carolina's Coastal Plain --- 1988, an overview: South Carolina Water Resources Commission Report No. $167,127 \mathrm{p}$.

1993, Pumping tests of the Coastal Plain aquifers in South Carolina: South Carolina Water Resources Commission Report 174, $52 \mathrm{p}$.

Odermatt, J.R., 1994, Natural chromatographic separation of benzene, toluene, ethylbenzene, and xylenes (BTEX compounds) in a gasoline contaminated ground water aquifer: Organic Geochemistry, v. 21, no. 10, p. 1141-1150.

Pardieck, D.L., Bouwer, E.J., and Stone, A.T., 1992, Hydrogen peroxide use to increase oxidant capacity for in situ bioremediation of contaminated soils and aquifers - a review: Journal of Contaminant Hydrology, v. 9, p. 221-242.

Park, A.D., 1985, The ground-water resources of Charleston, Berkeley, and Dorchester Counties, South Carolina: South Carolina Water Resources Commission Report 139, 146 p.

Petkewich, M.D., Vroblesky, D.A., Robertson, J.F., and Bradley, P.M., in press, Water-quality, water-level, and lake-bottom-sediment data collected from the Defense Fuel Supply Point and adjacent properties, Hanahan, South Carolina, 1990-96: U.S. Geological Survey Open-File Report 96-488.
Rabus, Ralf, Nordhaus, Ralph, Ludwig, Wolfgang, and Widdel, Friedrich, 1993, Complete oxidation of toluene under strictly anoxic conditions by a new sulfate-reducing bacterium: Applied and Environmental Microbiology, v. 59, p. 1444-1451.

RMT, Inc., 1987, Final report, off-site air monitoring and data collection, Defense Fuel Supply Point, Charleston, South Carolina: Consultant's report to Defense Fuel Supply Center, July 1987, 33 p.

1988a, Final Report, aquifer evaluation, Defense Fuel Supply Point, Charleston, South Carolina: Consultant's report to Defense Fuel Supply Center, January 1988, 22 p.

1988b, Final Report, remedial alternatives report, Defense Fuel Supply Point, Charleston, South Carolina: Consultant's report to Defense Fuel Supply Center, February 1988, $44 \mathrm{p}$.

1989a, Monitoring well installation report, Defense Fuel Supply Point, Charleston, South Carolina: Consultant's report to Southern Division Naval Facilities Engineering Command, Charleston, South Carolina, August $1989,9 \mathrm{p}$.

$-1989 \mathrm{~b}$, Monitoring well inventory report, Defense Fuel Supply Point, Charleston, South Carolina: Consultant's report to Southern Division Naval Facilities Engineering Command, Charleston, South Carolina, September 1989, $8 \mathrm{p}$.

1989c, Round 1 analytical report, Defense Fuel Supply Point, Charleston, South Carolina: Consultant's report to Southern Division Naval Facilities Engineering Command, Charleston, South Carolina, September 1989, $10 \mathrm{p}$.

1989d, JP-4 remediation at the Defense Fuel Supply Point, Charleston, South Carolina: Consultant's report to Southern Division Naval Facilities Engineering Command, Charleston, South Carolina, 118 p. 
1990, Round 2 analytical report, Defense Fuel Supply Point, Charleston, South Carolina: Consultant's report to Southern Division Naval Facilities Engineering Command, Charleston, South Carolina, January 1990, $29 \mathrm{p}$.

1991, Operations and maintenance manual, ground-water remediation system, Defense Fuel Supply Point Site, Charleston, South Carolina, $19 \mathrm{p}$.

Schocher, R.J.; Seyfried, Birgit; Vazquez, Francisco; and Zeyer, Josef, 1991, Anaerobic degradation of toluene by pure cultures of denitrifying bacteria: Archives of Microbiology, v. 157, p. 7-12.

Science Applications International Corporation, 1985, Installation restoration program, Phase II -- Confirmation/quantification, stage 1, Charleston Air Force Base, South Carolina: Consultants report to Military Airlift Command, Scott AFB, Illinois, p. 4-20.

Sheehan, P.J., Schneiter, R.W., and Gersberg, R.M., 1988, Bioreclamation of gasoline-contaminated ground water without oxygen additions: in Proceedings of the Second National Outdoor Action Conference on Aquifer Restoration, Ground Water Monitoring and Geophysical Methods, National Water Well Association, Dublin, Ohio, p. 183-199.

Smolenski, W.J., and Suflita, J.M., 1987, Biodegradation of cresol isomers in anoxic aquifers: Applied and Environmental Microbiology, v. 53, p. 710-716.

Stookey, L.L., 1970, FerroZine, a new spectrophotometric reagent for iron: Analytical Chemistry, v. 42 , p. 779-781.

Stumm, Werner, and Morgan, J.J., 1981, Aquatic chemistry ( $2 \mathrm{~d}$ ed.), John Wiley \& Sons, New York, $780 \mathrm{p}$.

Trimmell, M.L., 1987, Installation of hydrocarbon detection wells and volumetric calculations within a confined aquifer: Presented at the Petroleum Hydrocarbons and Organic Chemicals in Ground Water - Prevention, Detection and Restoration Conference and Exposition, National Water Well Association and American Petroleum Institute, Houston, Texas.

U.S. Army Environmental Hygiene Agency, 1975, Water-quality geohydrologic consultation no. 24-020-76, Defense Fuel Support Point, Charleston, South Carolina, 12-13 November 1975, $31 \mathrm{p}$.

1977, Water-quality geohydrologic consultation no. 24-0026-77, Defense Fuel Support Point, Charleston, South Carolina, November 1975-May 1977, 38 p.

1979, Biodegradation of fuel system icing inhibitor discharges from Defense Fuel Support Point oil/water separators: Water quality treatability study No. 32-24-0183-80, October 22- November 28, 1979, 24 p.

-1980, Environmental quality survey no. 32-24-1651-81, Defense Fuel Support Point, Charleston, South Carolina, January 1980, $16 \mathrm{p}$.

-1985, Environmental quality survey no. 32-24-1602-85, Defense Fuel Support Point, Charleston, South Carolina, 25-28 February $1985,28 \mathrm{p}$.

-1988, Environmental quality survey and spill plans, implementation review study no. 32-24-7070-88, Defense Fuel Support Point, Charleston, South Carolina, 1-5 February 1988, 13 p.

U.S. Environmental Protection Agency, 1983, Methods for chemical analysis of water and waste, EPA-600/4-79-020: U.S. Environmental Protection Agency, Washington, D.C.

-1986, Test methods for evaluating solid waste, Physical/chemical methods, SW-846 (3rd ed.): U.S. Environmental Protection Agency, Washington, D.C., 1919 p.

-1991, Maximum contaminant levels, in U.S. Code of Federal Regulations, Title 40, Part 141, National primary drinking water regulations: July 1, 1991.

-1996, Drinking water regulations and health advisories: EPA 822-R-96-001, February $1996,15 \mathrm{p}$. 
Vroblesky, D.A., Robertson, J.F., Fernandez, Mario, and Aelion, C.M., 1992, The permeable-membrane method of passive soil-gas collection: Sixth National Outdoor Action Conference, National Water Well Association, May 5 to 13, 1992, Las Vegas, Nevada.

Vroblesky, D.A., and Chapelle, F.H., 1994, Temporal and spatial changes of terminal electron accepting processes in a petroleum-hydrocarbon-contaminated aquifer and the significance for contaminant biodegradation: Water Resources Research, v. 30, no. 5, p. 1561-1570.

Vroblesky, D.A., Robertson, J.F., and Rhodes, L.C., 1995, Stratigraphic trapping of shallow petroleum contamination: Ground-Water Monitoring and Remediation, Spring, 1995, p. 177-183.
Vroblesky, D.A., Bradley, P.M., and Chapelle, F.H., 1996, Influence of electron donor on the minimum sulfate concentration required for sulfate reduction in a petroleum hydrocarboncontaminated aquifer: Environmental Science and Technology, v. 30, no. 4, p. 1377-1381

Ward, L.W., Blackwelder, B.W., Gohn, G.S., and Poore, R.Z., 1979, Stratigraphic revision of Eocene, Oligocene, and lower Miocene formations of South Carolina: Geologic Notes, v. 23 , no. 1, p. 2-23.

Wood, W.W., 1976, Guidelines for collection and field analysis of ground-water samples for selected unstable constituents: U.S. Geological Survey Techniques of Water-Resources Investigations, book 1, chap. D2, $24 \mathrm{p}$. 


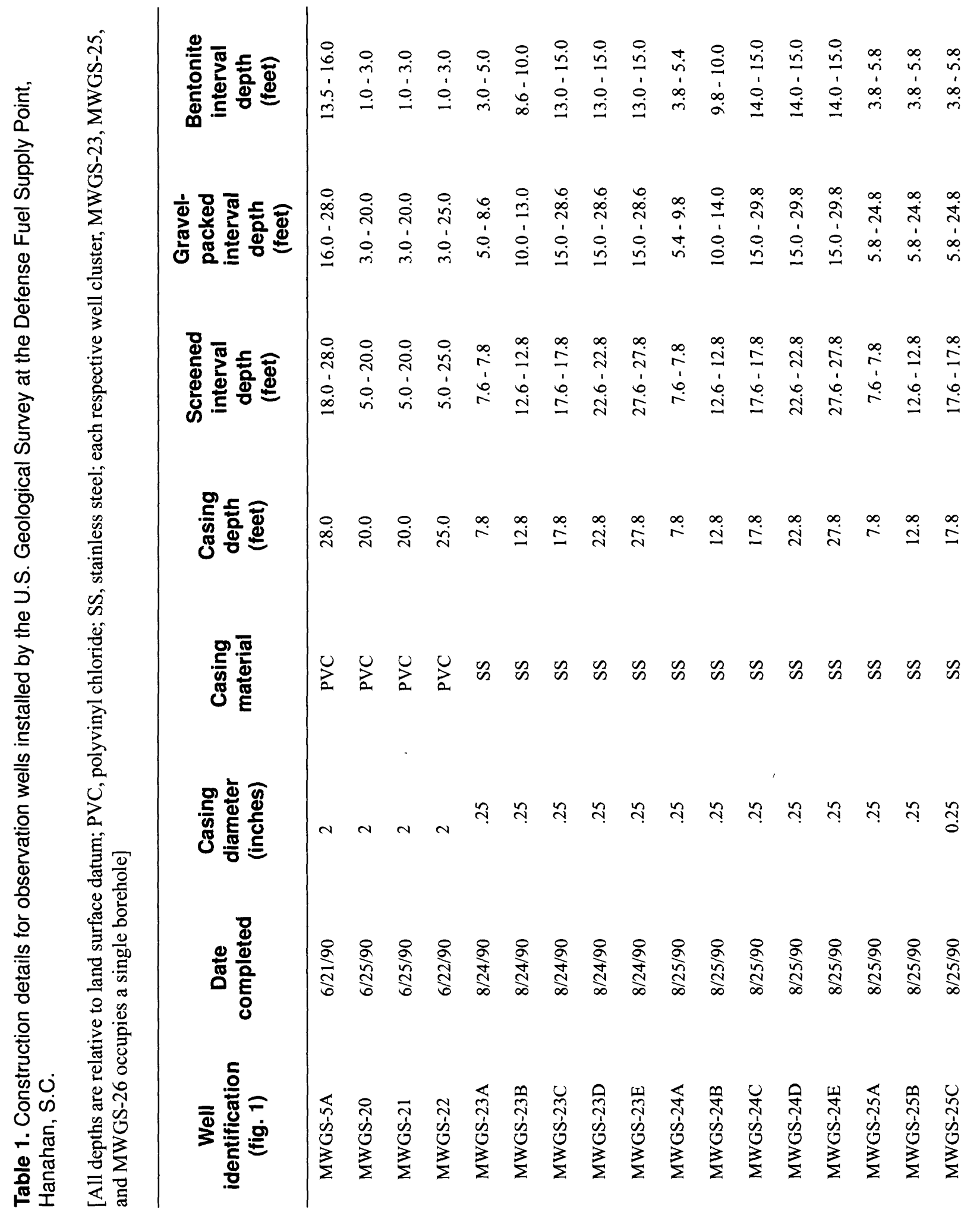

54 Remediation of Petroleum Hydrocarbon-Contaminated Ground Water in the Vicinity of a Jet-Fuel Tank Farm, Hanahan, South Carolina 


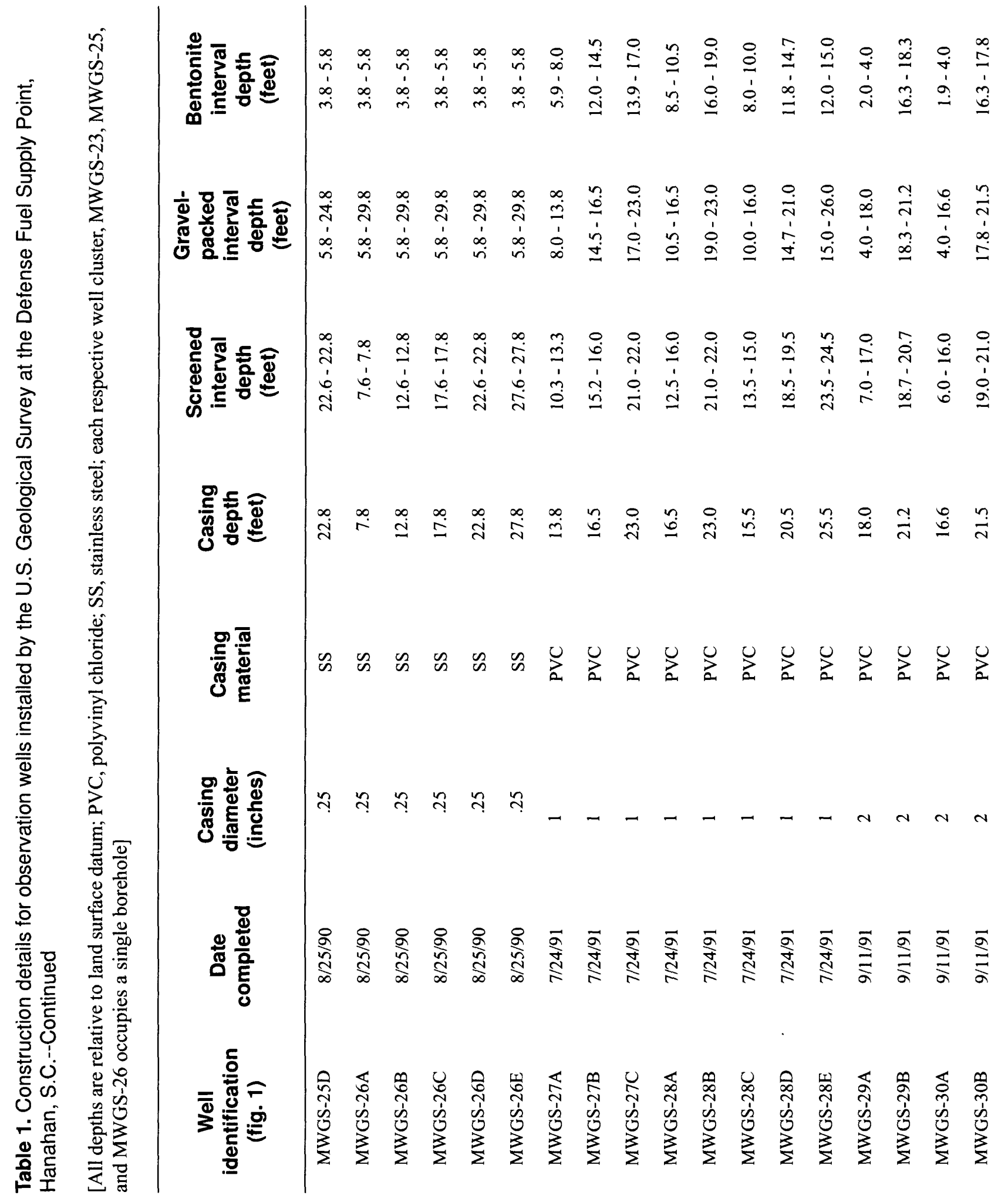




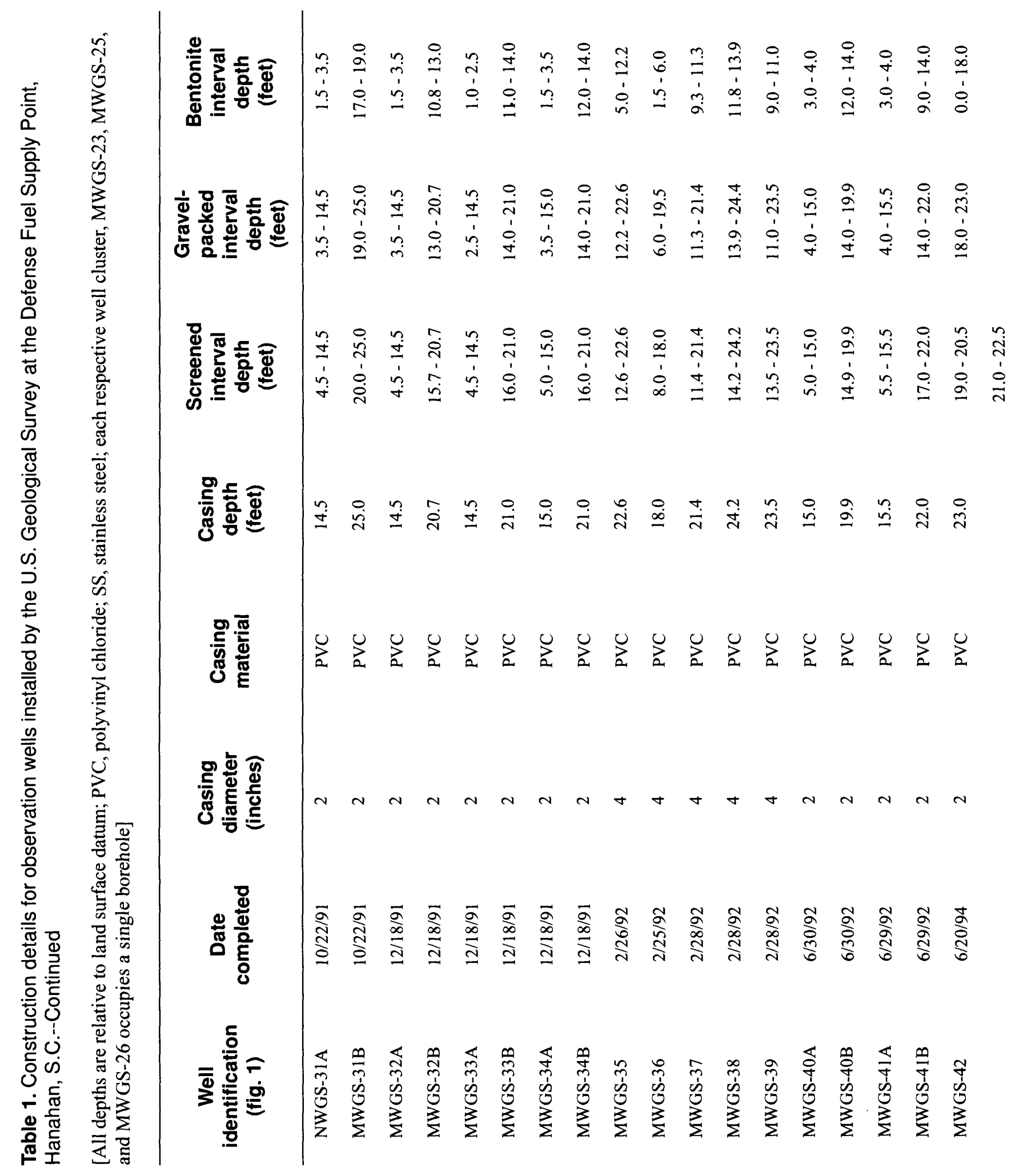

56 Remediation of Petroleum Hydrocarbon-Contaminated Ground Water in the Vicinity of a Jet-Fuel Tank Farm, 


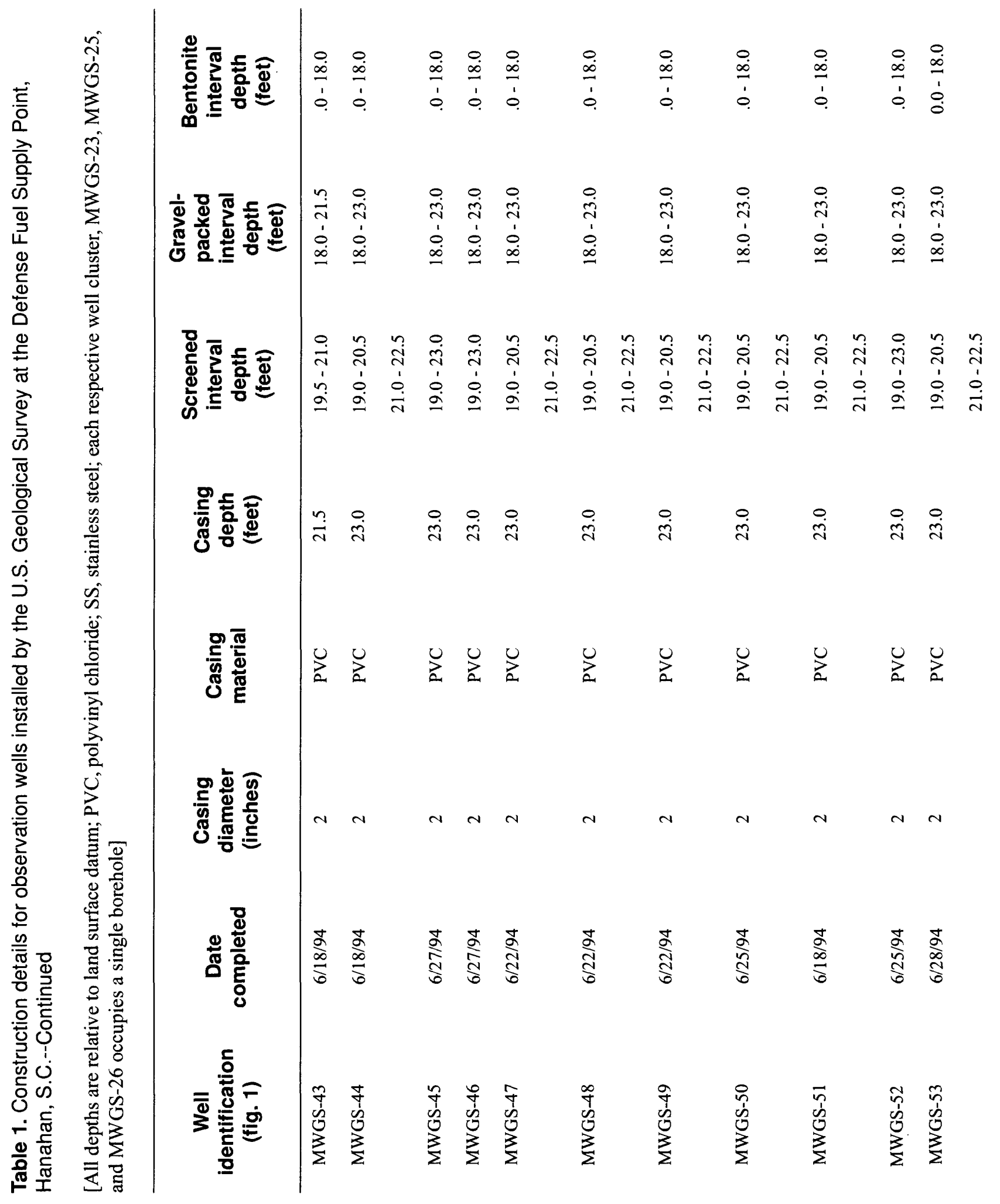

Table $1 \quad 57$ 


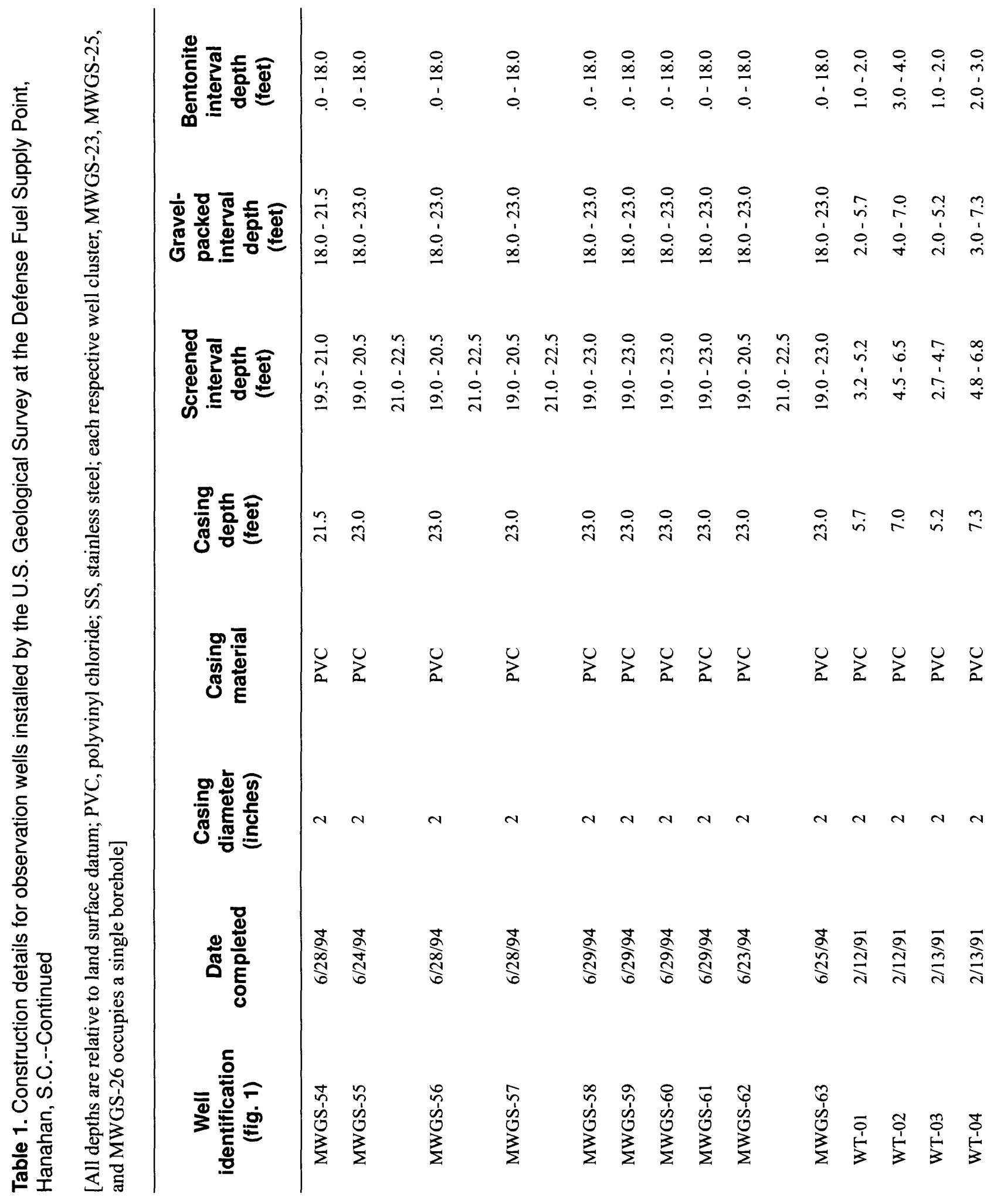




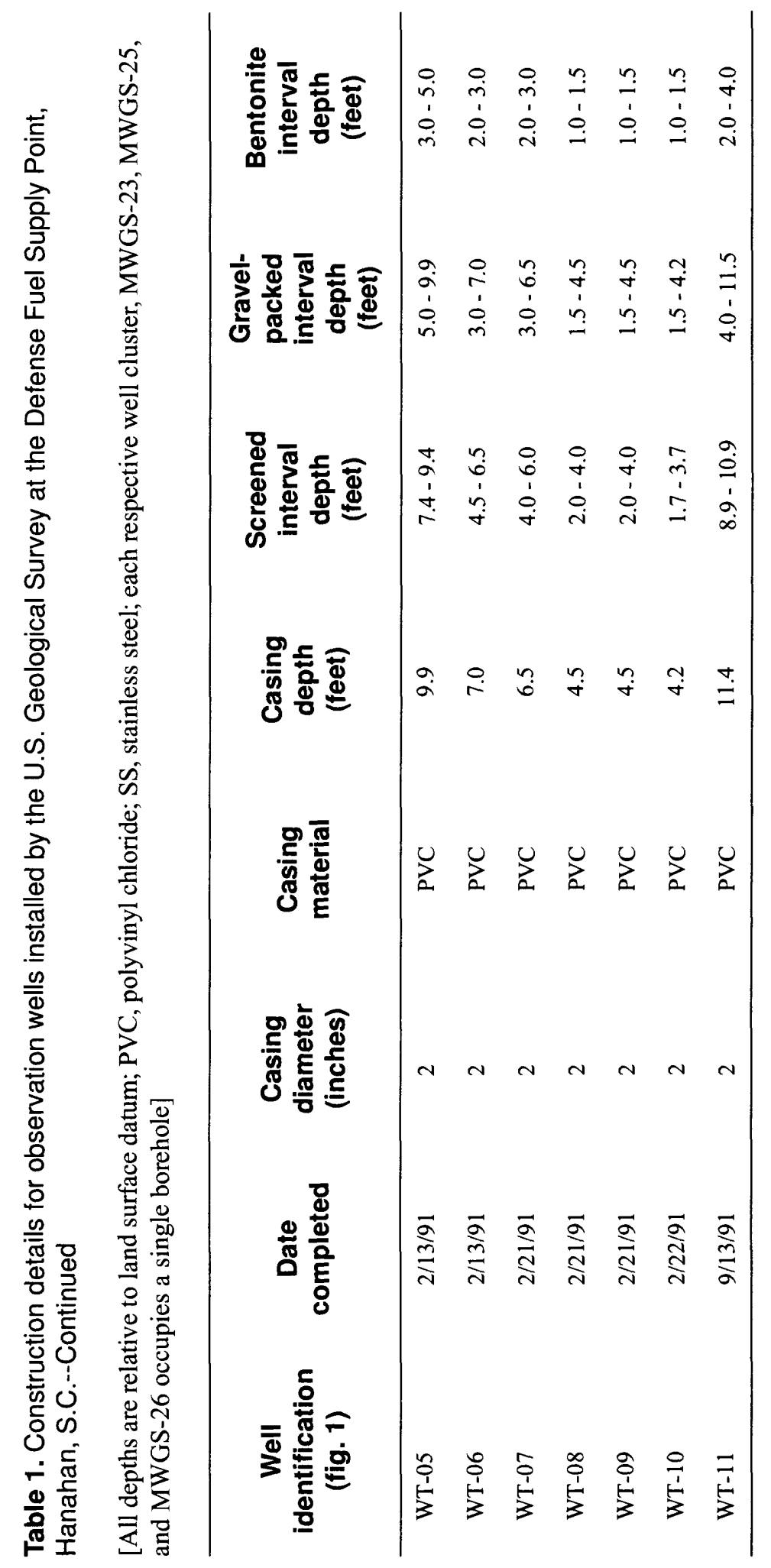


Table 2. Construction details for privately owned wells and monitoring wells installed during previous investigations in the vicinity of the Defense Fuel Supply Point, Hanahan, S.C.

[All depths are relative to land surface datum; --, information not available; Depths of W-series, B-series, and PW wells based on tapedown measurements]

\begin{tabular}{|c|c|c|c|c|c|}
\hline $\begin{array}{c}\text { Well } \\
\text { identification } \\
\text { (fig. 1) }\end{array}$ & $\begin{array}{l}\text { Casing } \\
\text { diameter } \\
\text { (inches) }\end{array}$ & $\begin{array}{l}\text { Casing } \\
\text { depth } \\
\text { (feet) }\end{array}$ & $\begin{array}{c}\text { Screened } \\
\text { interval depth } \\
\text { (feet) }\end{array}$ & $\begin{array}{c}\text { Gravel-pack } \\
\text { interval } \\
\text { depth } \\
\text { (feet) }\end{array}$ & $\begin{array}{c}\text { Bentonite } \\
\text { interval } \\
\text { depth } \\
\text { (feet) }\end{array}$ \\
\hline MW-04 & 2 & 26.0 & $6.0-26.0$ & $4.4-28.5$ & $3.3-4.4$ \\
\hline MW-05 & 2 & 12.0 & $2.0-12.0$ & $2.3-17.0$ & $1.6-2.3$ \\
\hline MW-06 & 2 & 21.7 & $1.7-21.7$ & $2.0-22.0$ & $0.9-2.0$ \\
\hline MW-07 & 2 & 18.0 & $8.0-18.0$ & $7.5-18.5$ & $5.3-7.5$ \\
\hline MW-08 & 2 & 12.0 & $2.0-12.0$ & $1.6-17.0$ & $0.8-1.6$ \\
\hline MW-09 & 2 & 11.9 & $1.9-11.9$ & $2.0-13.0$ & $1.0-2.0$ \\
\hline MW-10 & 2 & 12.0 & $2.0-12.0$ & $2.2-13.0$ & $1.0-2.2$ \\
\hline MW-11 & 2 & 17.5 & $2.5-17.5$ & $1.0-20.0$ & $0.0-1.0$ \\
\hline MW-11A & 2 & 34.0 & $26.5-31.5$ & $23.0-34.0$ & $22.0-23.0$ \\
\hline MW-12(east) & 2 & 31.5 & $26.5-31.5$ & $23.0-34.0$ & $22.0-23.0$ \\
\hline MW-12A(west) & 2 & 17.0 & $7.0-17.0$ & $5.0-19.5$ & $3.0-5.0$ \\
\hline MW-15 & 2 & 15.0 & $5.0-15.0$ & $3.0-17.5$ & $2.0-3.0$ \\
\hline MW-16 & 2 & 13.5 & $3.5-13.5$ & $1.5-15.0$ & $0.0-1.5$ \\
\hline MW-17 & 2 & 15.0 & $5.0-15.0$ & $3.0-17.5$ & $1.0-3.0$ \\
\hline MW-18 & 2 & 19.0 & $9.0-19.0$ & $7.0-19.5$ & $4.5-7.0$ \\
\hline MW-19 & 2 & 29.5 & $9.5-19.5$ & $6.5-20.0$ & $4.8-6.5$ \\
\hline W-001 & 2 & 19.5 & -- & -- & -- \\
\hline W-002 & 2 & 14.0 & -- & -- & -- \\
\hline W-003 & 2 & 28.0 & -- & -- & -- \\
\hline W-103 & 6 & 35.0 & 30 -foot length & -- & -- \\
\hline W-105 & 2 & 21.3 & -- & -- & -- \\
\hline W-107 & 6 & 29.4 & -- & -- & - \\
\hline W-108 & 6 & 34.5 & 30-foot length & -- & -- \\
\hline
\end{tabular}


Table 2. Construction details for privately owned wells and monitoring wells installed during previous investigations in the vicinity of the Defense Fuel Supply Point, Hanahan, S.C.--Continued

[All depths are relative to land surface datum; --, information not available; Depths of W-series, B-series, and PW wells based on tapedown measurements]

\begin{tabular}{|c|c|c|c|c|c|}
\hline $\begin{array}{c}\text { Well } \\
\text { identification } \\
\text { (fig. 1) }\end{array}$ & $\begin{array}{l}\text { Casing } \\
\text { diameter } \\
\text { (inches) }\end{array}$ & $\begin{array}{l}\text { Casing } \\
\text { depth } \\
\text { (feet) }\end{array}$ & $\begin{array}{c}\text { Screened } \\
\text { interval depth } \\
\text { (feet) }\end{array}$ & $\begin{array}{l}\text { Gravel-pack } \\
\text { interval } \\
\text { depth } \\
\text { (feet) }\end{array}$ & $\begin{array}{c}\text { Bentonite } \\
\text { interval } \\
\text { depth } \\
\text { (feet) }\end{array}$ \\
\hline B- 102 & 6 & 33.2 & 30-foot length & -- & - \\
\hline B-103 & 6 & 33.2 & 30-foot length & -- & -- \\
\hline B-105 & 6 & 34.1 & 30-foot length & -- & -- \\
\hline B-106 & 6 & 34.1 & 30 -foot length & -- & -- \\
\hline B-109 & 6 & 33.3 & 30-foot length & -- & -- \\
\hline PW-01A & 1.5 & 16.5 & -- & - & -- \\
\hline PW-01B & 1.5 & 17.9 & -- & -- & -- \\
\hline PW-02 & 1.5 & 15.0 & -- & -- & -- \\
\hline PW-05 & 1.5 & 19.4 & -- & -- & - \\
\hline NWS-12-1 & 2 & 20.0 & $15.0-20.0$ & $13.0-20.0$ & -- \\
\hline NWS-12-2 & 2 & 18.0 & $13.0-18.0$ & $11.0-18.0$ & -- \\
\hline NWS-12-3 & 2 & 12.0 & $7.0-12.0$ & $5.0-12.0$ & - \\
\hline NWS-12-4 & 2 & 13.0 & $8.0-13.0$ & $6.0-13.0$ & -- \\
\hline NWS-12-5 & 2 & 13.0 & $8.0-13.0$ & $6.0-13.0$ & -- \\
\hline NWS-12-7 & 2 & 38.0 & $8.0-38.0$ & $5.0-38.0$ & $3.0-5.0$ \\
\hline
\end{tabular}

